\author{
UNIVERSIDADE DE SÃO PAULO \\ FACULDADE DE FILOSOFIA, LETRAS E CIÊNCIAS HUMANAS \\ DEPARTAMENTO DE GEOGRAFIA \\ PROGRAMA DE PÓS-GRADUAÇÃO EM GEOGRAFIA HUMANA
}

Memória e transformação urbana: uma análise do patrimônio

ferroviário em Campo Grande - MS

Helder Gustavo Marques

São Paulo

2014 


\author{
UNIVERSIDADE DE SÃO PAULO \\ FACULDADE DE FILOSOFIA, LETRAS E CIÊNCIAS HUMANAS \\ DEPARTAMENTO DE GEOGRAFIA \\ PROGRAMA DE PÓS-GRADUAÇÃO EM GEOGRAFIA HUMANA
}

\title{
Memória e transformação urbana: uma análise do patrimônio ferroviário em Campo Grande - MS
}

\section{Helder Gustavo Marques}

Dissertação apresentada ao Programa de PósGraduação em Geografia Humana, do Departamento de Geografia da Faculdade de Filosofia, Letras e Ciências Humanas da Universidade de São Paulo, para obtenção do título de Mestre na área de Geografia Humana.

De Acordo: smone suforu

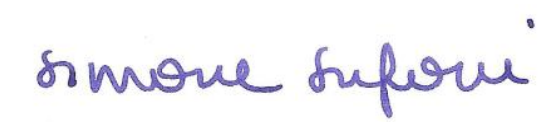

\author{
Orientadora: Prof $^{\mathrm{a}}$. Dr ${ }^{\mathrm{a}}$. Simone Scifoni
}

\section{Exemplar Corrigido}

\section{V.1}

São Paulo 
MARQUES, Helder Gustavo.

Título: Memória e transformação urbana: uma análise do patrimônio ferroviário em Campo Grande-MS.

Aprovado em:

Banca Examinadora

Prof. Dr.

Assinatura:

Prof. Dr.

Assinatura:

Prof. Dr.

Assinatura: 


\section{Agradecimentos}

Dedico este trabalho a memória do meu avô Amantino Marques dos Santos, maior símbolo de honestidade e hombridade que conheci, ferroviário durante quase toda sua vida, homem simples que sempre se dedicou a sua família de forma incondicional.

A minha mãe, Zoraide Rodrigues, mulher batalhadora e guerreira, que sempre foi exemplo máximo de amor e ternura.

Aos meus irmãos Ana Karina, Humberto e Marco, que mesmo distantes sempre nos mantemos unidos.

A minha companheira Natasha, por toda compreensão e apoio nos momentos difíceis, pela amizade e amor sincero.

À querida orientadora, Simone, que abraçou minha causa, sempre presente em todo processo de execução desta pesquisa, militante da memória da classe operária de nosso país marcado pela memória oficial imposta pelo Estado.

Agradeço aos professores com quem tive aula durante a pós-graduação: Isabel Alvarez, Francisco Capuano Scarlato, Beatriz Mugayar Kuhl, Simone Scifoni e Amalia Inês Geraiges de Lemos. Todos tiveram grande contribuição teórica para o desenvolvimento deste trabalho.

À banca de qualificação, composta por Flávia Brito do Nascimento e Francisco Capuano Scarlato, que contribuíram de forma magnífica com apontamentos ricos e precisos que foram de grande contribuição para a execução desta dissertação.

Aos colegas de "turma" Luisa, Mateus e Priscila, por sua companhia e apoio, e principalmente pelo compartilhamento de ideias através dos colóquios e reuniões que realizamos durante todo o período da pós-graduação.

A FAPESP pelo importante apoio financeiro que tornou possível a realização desta pesquisa e manutenção do presente mestrando na cidade de São Paulo.

E em especial a todos os ferroviários, principalmente os que fizeram parte da história da NOB/RFFSA, que dedicaram suas vidas ao trabalho árduo na ferrovia, espero que de alguma forma este trabalho possa representar um pouco de sua história, de sua memória. 
"A memória é a consciência inserida no tempo."

Fernando Pessoa 


\section{Resumo}

O presente trabalho tem como objeto de investigação as modificações ocorridas no complexo ferroviário na cidade de Campo Grande - MS, partindo da análise sobre o desenvolvimento da cidade associado com a chegada da Noroeste do Brasil - NOB, como parte de um processo de expansão do capitalismo e modernização do campo, entendendo sua urbanização como resultado disso. Em um segundo momento, foi realizada uma analise sobre a ferrovia enquanto referencial de memória coletiva e urbana, servindo assim como "resistência" dentro do processo de valorização do patrimônio. Por último, buscou-se entendimento do patrimônio ferroviário enquanto âncora no processo de valorização das cidades, como parte de um sistema de "reestruturação" do capitalismo na contemporaneidade. Desta forma, este trabalho constitui-se como uma reflexão sobre a relação entre a preservação patrimonial dos bens de uma extinta ferrovia frente ao processo de reinserção de antigos espaços nos novos contextos urbanos, apontando o quão contraditório é esta relação que muitas vezes utiliza-se do discurso do patrimônio para atrair e gerar valorização a estas antigas áreas.

Palavras-chave: Patrimônio ferroviário, requalificação urbana, memória. 


\begin{abstract}
The present work aims to investigate the changes in the railway complex in the city of Campo Grande - MS, based on an analysis of the development of the city associated with the arrival of Noroeste do Brasil - NOB, as part of the process of capitalism expansion and the countryside modernization, understanding its urbanization as a result of this. In a second step, an analysis of the railroad as a reference of urban and collective memory was held, thus serving as "resistance" in the heritage valorization process. Finally, was sought to understand the railroad heritage while anchor in the cities valorization process, as part of a system of "restructuring" the contemporary capitalism. As a result, this work constitutes as a reflection regarding the relationship between heritage property preservation of a defunct railroad against the reintegration of old spaces in new urban contexts, pointing how pointing how contradictory is this relationship that often makes use of the speech of heritage to attract and generate the valorization of these old areas.
\end{abstract}

Key-words: Railroad heritage, urban renewal and memory. 


\section{Sumário}

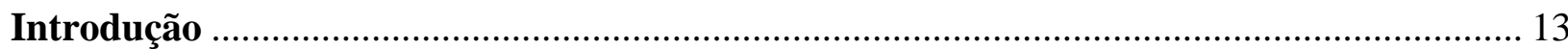

Capitulo 1: A Estrada de Ferro Noroeste do Brasil e Campo Grande: Bases preliminares.18

1.1 Algumas considerações sobre a relação das ferrovias com o capitalismo ........................... 21

1.2 Ferrovias e Brasil: Um breve histórico ........................................................................... 27

1.3 A Construção da Estrada de Ferro Noroeste do Brasil: entre objetivos e fins...................... 30

1.4 A NOB e Campo Grande: Nas entrelinhas da História........................................................ 37

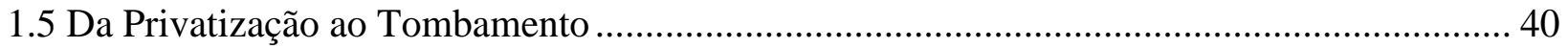

Capítulo 2: O tombamento e as ações sobre o patrimônio ferroviário: A Transformação espacial urbana do complexo ferroviário em Campo Grande ............................................ 46

2.1 Como Surge o Patrimônio Ferroviário................................................................................... 46

2.2. O Patrimônio da NOB como Complexo Ferroviário ............................................................ 52

2.3 Os Níveis de Tombamento do Complexo Ferroviário da NOB em Campo Grande ............. 69

Capitulo 3: Entre memória e valorização: Uma análise sobre o processo de revitalização proposta ao complexo ferroviário em Campo Grande-MS ......................................... 74

3.1 As intervenções Realizadas no Complexo Ferroviário de Campo Grande-MS ..................... 74

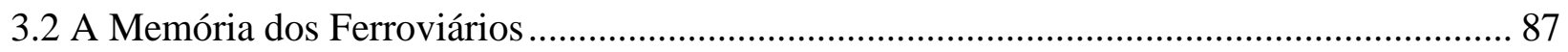

3.3 As Intervenções na Perspectiva de Quem? .................................................................. 93

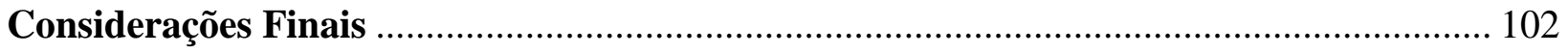

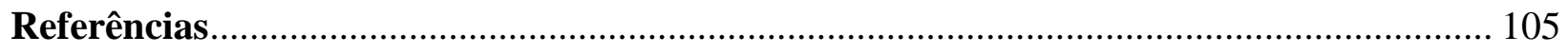

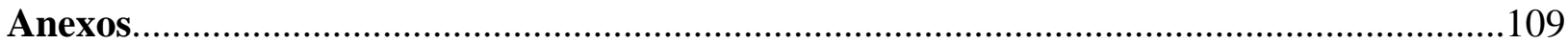




\section{Lista de Figuras}

Figura 1. Mapa do Traçado da Estrada de Ferro Noroeste do Brasil........................................... 18

Figura 2. Mapa da Bacia do Rio Prata ..................................................................................... 19

Figura 3. Mapa do Traçado da Estrada de Ferro Noroeste do Brasil, Campo Grande em Destaque ao Centro, Ponto de Encontro das Duas Frentes de Trabalho......................................................... 21

Figura 4. Mapa Ligação Sorocabana e NOB ………………………………………………..... 33

Figura 5. Mapa do Traçado Atlântico - Pacífico ................................................................................ 34

Figura 6. Planta do Traçado Urbano de Campo Grande em 1939 .................................................. 38

Figura 7. Complexo Ferroviário em Campo Grande .................................................................. 55

Figura 8. Ruas que Compreendem o Complexo Ferroviário em Campo Grande .......................... 56

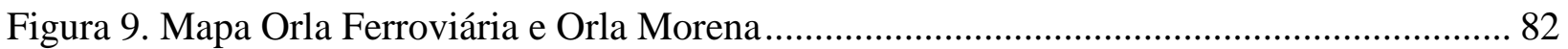

Figura 10. Localização dos pontos de coleta de dados, Feira do bairro Cabreúva na Orla ........... 97 


\section{Lista de Tabelas}

Tabela 1. Síntese dos bens tombados da NOB em Campo Grande ......................................... 85

Tabela 2. Questionário aplicado em trabalho de campo ........................................................ 96

Tabela 3. Tabulação das Respostas do questionário aplicado em trabalho de campo ................. 97 


\section{Lista de Fotos}

Foto 1. Complexo ferroviário de Campo Grande na década de 30................................................. 55

Foto 2. Estação em 1916 ……………………………......................................................... 58

Foto 3. Estação em 1924 ……………………………………………………………..... 58

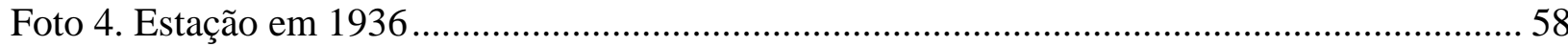

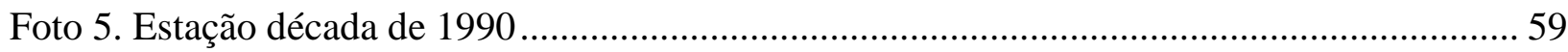

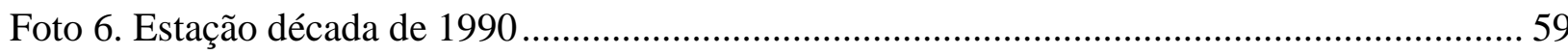

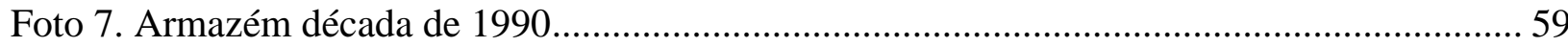

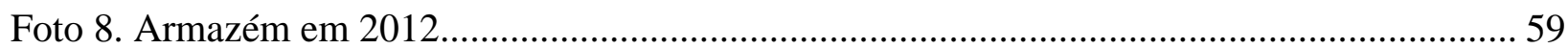

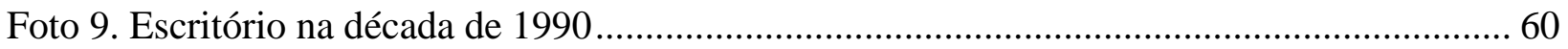

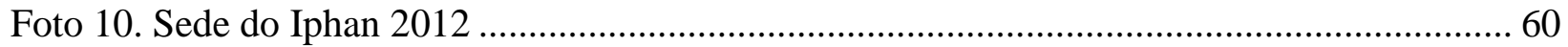

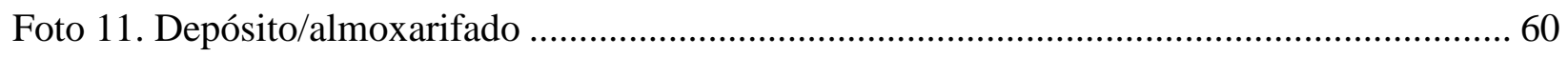

Foto 12. Galpão de manutenção e limpeza dos vagões década de 1970......................................... 60

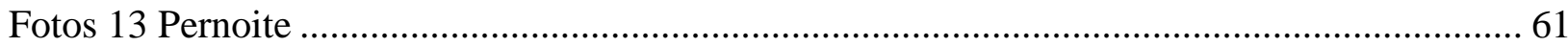

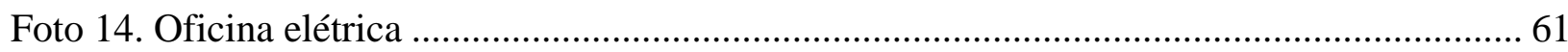

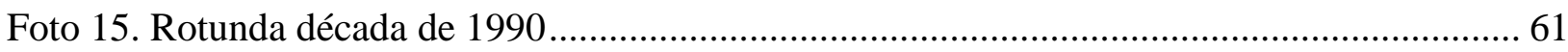

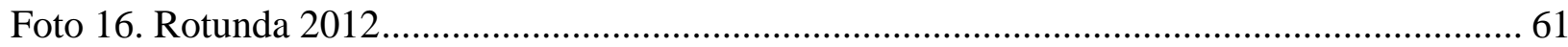

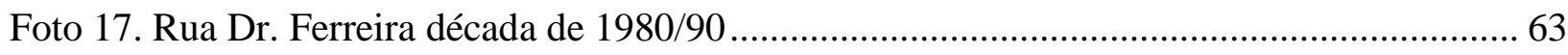

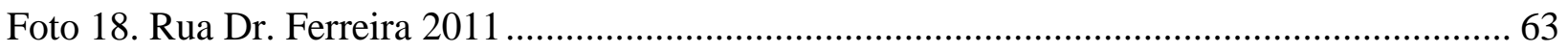

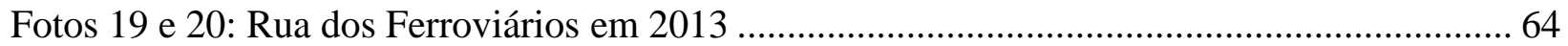

Fotos 21 e 22. Primeira casa de alvenaria do complexo ferroviário em Campo Grande em 2013 ...

Fotos 23 e 24. Rua 14 de Julho - casas de funcionários intermediários........................................ 65

Foto 25 e 26. Casarão (uso residencial) na Av. Calógeras em frente à Estação Ferroviária em

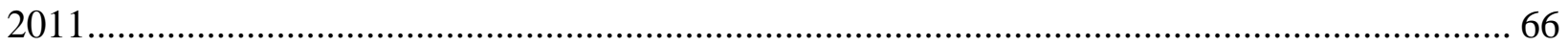

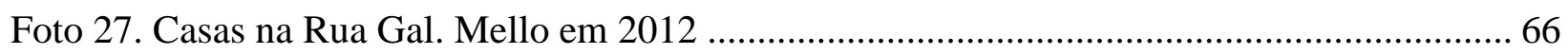

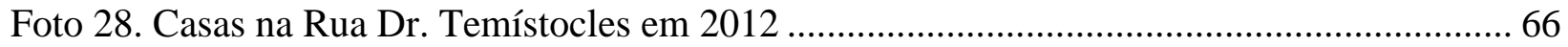

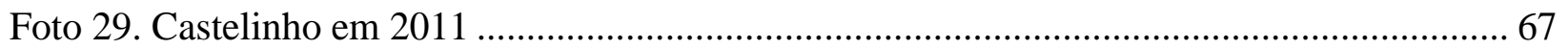

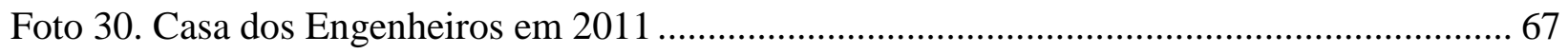

Foto 31. Escola Álvaro Martins Neto - 2011 .................................................................................. 68 
Foto 32: Casa de Dança Bolero, antigo clube Noroeste

Foto 33 e 34. Casarão (uso residencial) na Av. Calógeras em frente à Estação Ferroviária em 2014. 79

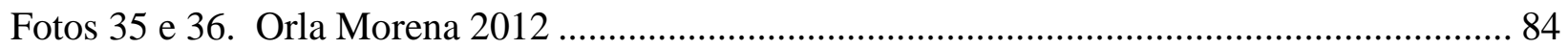

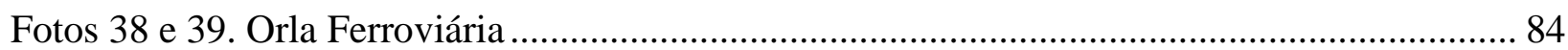




\section{Introdução}

A ferrovia Noroeste do Brasil - NOB, Companhia Estrada de Ferro Noroeste do Brasil CEFNOB ou ainda Estrada de Ferro Noroeste do Brasil - EFNOB foi uma ferrovia de penetração, que teve importante papel de conexão territorial, sendo importante do ponto de vista geopolítico, econômico social e tecnológico. Sua construção revela o desejo do então governo Federal em fortalecer a manutenção de suas terras a oeste, na divisa com Paraguai e Bolívia.

Ao proteger as fronteiras brasileiras inaugurou novos mercados, seja fundando cidades, ou elevando vilas a tal categoria, encurtando as distancias e facilitando o transbordo de mercadorias e de passageiros, transportando uma série de imigrantes que através da ferrovia viram uma nova possibilidade de trabalho, seja em sua construção ou com a agricultura e pecuária nas terras do distante Mato Grosso.

As ferrovias, no geral, foram importantes na formação urbana de diversas cidades, impondo seu ordenamento espacial, modernizando os assentamentos urbanos, e criando no entorno das estações um novo desenho de centralidade, que não se limitava apenas a consolidação comercial, mas também um ponto de encontro da sociedade naquele momento, constituindo e construindo novas relações sociais.

Para compreender a complexidade de relações materiais e imateriais, no que tange aos processos de construção das ferrovias e de seus complexos ferroviários, a discussão sobre a memória ferroviária passa pela reflexão do conceito de lugar de memória, onde o processo histórico de longa duração acabou por tipificar uma memória social, um jeito único de viver, que trata da categoria ferroviária em si, mas também da memória social da cidade inscrita no movimento do desenvolvimento urbano, em que a cidade se constrói sobre os elementos que a constitui. Por outro lado, a identidade ferroviária dependeu da criação de uma memória coletiva cuja evolução se deu e se dá, até hoje, sobre hábitos sociais correspondentes aos momentos históricos de seu desenvolvimento.

Em seu amplo sentido cultural, seja por sua importância tecnológica, territorial e social, a ferrovia foi um marco de grandes acontecimentos em Campo Grande, abrindo suas portas para o resto do país e atraindo pessoas para aquela distante porção do território brasileiro que ainda vivia sobre as sombras da guerra do Paraguai e remetia a instabilidade territorial do Brasil.

Esta gênese de tudo que estava por acontecer é o início desta análise, que agora será voltada para os aspectos gerais sobre a relação das ferrovias com a memória social. 
As ferrovias foram responsáveis por diversas transformações/fundação nas cidades as quais seu traçado cruzou no final do século XIX e ao longo do século XX. Foi o aparato tecnológico mais moderno na questão do transporte quando surgiu na Inglaterra, ao longo do tempo foi se consolidando como instrumento de transformações econômicas, territoriais, culturais e sociais. Em cada lugar onde foi instalado algum dispositivo ferroviário, segundo uma grande variedade formas e de redes, as empresas de transporte participaram do campo de disputas econômicas e financeiras.

Enquanto a rede ferroviária era construída em cada país, os fatores econômicos e produtivos estavam sendo pensados em termos regionais, porém em articulação com os fluxos externos, de tal maneira que a estratégia das elites interessadas na ferrovia era não somente manter seu espaço político, mas ampliá-lo internacionalmente.

Enquanto legítimo instrumento capitalista promoveu parte da integração nacional, expandido as fronteiras comerciais dinamizando o transporte de mercadorias, abastecendo o mercado interno e escoando a produção nacional para os portos, fortalecendo as relações comerciais internacionais brasileiras.

Junto a todo este desenvolvimento, propicio para o crescimento nacional, as ferrovias foram responsáveis pela formação de muitas cidades no Brasil, pois ao longo dos trilhos conforme as fronteiras iam sendo rompidas vilarejos se formavam e pequenos aglomerados já existentes ganhavam importância crescendo de acordo com a demanda criada pelas ferrovias.

Matos (1974) caracteriza a ferrovia como a "força de uma realidade", que povoando e se desenvolvendo, transforma e modela uma paisagem urbana.

"A chegada dos trilhos é quase sempre um marco na história de uma cidade.
Com a estrada de ferro, vem todo o aparelhamento que ela exige, especialmente
quando a cidade, por alguma razão, é escolhida para sede de qualquer atividade
especial da estrada de ferro: armazéns, oficinas, escritórios, ponto de
cruzamento de trens ou local de baldeação. Tudo isso reflete sobre a vida da
cidade, pois constitui mercado de uma aração e estimula numerosas atividades
correlatas, dando ao local mais animação do que as demais cidades" (Matos,
1974 pg. 117).

Importante não apenas do ponto de vista econômico, as ferrovias se consolidavam pela importância na transformação do país, conectando as pessoas e encurtando as distâncias com os grandes centros brasileiros. Marcaram época e não perderam seu sentido ao longo dos anos, 
graças à importância que tiveram no desenvolvimento do Brasil, sendo lembrada, seja através da memória social, da mídia ou pela história oficial.

Monastirsky (2013) escreve que a simbologia da ferrovia ficou materializada tanto, pela experiência de vida propiciada, seja nos guichês de vendas ou nas gares de embarque, como pela presença monumental de suas edificações permeando a paisagem das cidades.

Além de ser associada como determinante ao desenvolvimento econômico e social, a simbologia da ferrovia está também na presença e configuração dos seus espaços (amplos pátios de manobras e de estoques de vagões), equipamentos (caixas d'águas, viadutos, oficinas, armazéns, rotundas e trilhos, esses com presença marcante no desenho urbano) (MONASTIRSKY, 2013).

No entanto, a ferrovia não é apenas constituída pela memória expressa em sua arquitetura e equipamentos tecnológicos, talvez a memória mais importante seja aquela transmitida por seus trabalhadores.

Homens de uniformes vinculados à grande empresa de transporte que durante a metade do século XX eram considerados uns dos trabalhadores mais bem empregados do país. E com eles, o charme e o romantismo das gares e das viagens de trens que tinham nas estações ferroviárias o espaço ideal (MONASTIRSKY, 2013).

A partir do processo de privatização imposto na década de 1990 ocorreu a redução dos fluxos do transporte ferroviário, tanto de carga quanto de passageiros, deixando de operar, ocasionando o sucateamento e o abandono, por falta de interesse da iniciativa privada que olhava apenas para os ramais ferroviários que ainda "produziam" lucro.

Com isso, surge a iniciativa, em um primeiro momento das prefeituras municipais e governos estaduais, de salvaguardar os patrimônios remanescentes das extintas ferrovias e posteriormente do governo federal, no caso de Campo Grande mais especificamente em 2009.

Em Campo Grande, junto com o processo de tombamento inicial em 1996, a prefeitura impôs um processo de revitalização urbana na cidade elencando trechos por onde os trilhos da NOB passavam como pontos de intervenções.

A ideia da realização deste trabalho vem da importância da chegada da NOB para o desenvolvimento do município, do interesse em analisar as intervenções realizadas no complexo ferroviário e as ações realizadas pelo poder público referente à preservação e valorização do patrimônio da extinta ferrovia. 
Portanto, questiona-se: qual o significado das intervenções realizadas no complexo ferroviário em Campo Grande?

Pretende-se entender a constituição deste patrimônio, apontando a urbanização ao redor da estação ferroviária como inicio de um processo formador do complexo urbano-central da cidade, partindo da ótica da chegada da ferrovia como momento do processo de expansão capitalista e modernização do campo, tendo a urbanização, como resultado disso. Levando em consideração o significado do lugar enquanto fruto da apropriação social e memória coletiva.

Partindo destas premissas poderemos entender se a revitalização reforçou a memória coletiva construída pela ferrovia ou apenas criou um novo ponto de valorização partindo da analise da relação do patrimônio ferroviário com as políticas públicas urbanas, e como se situam a cidade e seus moradores neste processo. Investigando se o destino dado ao patrimônio não é apenas um forte apelo à valorização, o utilizando como âncora neste processo.

Essas modificações deram um novo uso ao que estava abandonado, porém deve ser considerado se a memória e a identidade ferroviária se mantêm ainda presentes após todo este processo. E até mesmo se é possível que a valorização do lugar e da memória convivam no atual contexto da cidade, após o processo de revitalização.

Dessa forma, buscamos entender qual o significado das intervenções realizadas no complexo ferroviário em Campo Grande, seja do ponto de vista da memória das cidades, ou da valorização do espaço urbano a partir de um patrimônio que remete a história de Campo Grande.

Do ponto de vista metodológico, a pesquisa se divide em três eixos de discussão, o primeiro aponta a relação do desenvolvimento de Campo Grande com a chegada da ferrovia em um momento de expansão capitalista e modernização do campo brasileiro, onde sua urbanização foi produto desta relação, tendo com isso o surgimento de um novo contexto socioespacial na cidade.

O segundo eixo pretende analisar o papel da ferrovia como ponto central da constituição da memória urbana ou memória da cidade, analisado como esta memória esta sendo tratada no processo de revitalização vigente em Campo Grande, buscando o entendimento sobre o patrimônio e a sua relação com as transformações urbanas na atualidade.

O terceiro eixo aponta as questões que levam o patrimônio como âncora na valorização do espaço urbano, tendo a revitalização realizada no complexo ferroviário em Campo Grande como estudo de caso. 
Neste contexto, a seguinte dissertação esta dividida em três capítulos:

O primeiro capítulo propõe uma discussão sobre a construção da ferrovia NOB, sua relação com Campo Grande, e uma análise sobre o desenvolvimento do município sendo alavancado pela ferrovia. Com isso, pretendeu se debater a construção de uma identidade ferroviária no município, apresentando a ideia de que a ferrovia influenciou um novo cotidiano na cidade.

O segundo capítulo tratou dos tombamentos e de um inventário deste patrimônio ferroviário tombado.

Por último, o terceiro capítulo apresenta uma análise das intervenções no complexo ferroviário e sua relação com a memória coletiva, tendo como suporte entrevistas realizadas nos trabalhos de campo.

Para a execução deste trabalho foram realizados, levantamento bibliográfico, conceituação teórica e pesquisas de campo.

Para os trabalhos de campo foram realizadas entrevistas com ex-ferroviários, na forma de vídeo com roteiro flexível, visando obter o máximo de informações possível sobre o trabalho e as relações criadas a partir da ferrovia.

As entrevistas com ex-ferroviários foram baseadas em um roteiro constituído por três temas propostos: a relação com a ferrovia, NOB e Campo Grande e a opinião pessoal a respeito das intervenções no complexo ferroviário, principalmente se as obras refletem a memória ferroviária. Apesar da entrevista seguir um roteiro prévio, foi aberto ao entrevistado à possibilidade de relatar assuntos por ele considerados relevantes dentro do universo da pesquisa proposta.

Foram entrevistados oito ex-ferroviários, escolhidos de forma pontual, cada um com uma função específica na ferrovia, buscando relatos sobre o trabalho e as relações sociais criadas pelas relações de trabalho. As entrevistas foram inseridas ao longo do capitulo três, visando "amarrar" a teoria e consequente análise com fatos reais vividos por estas pessoas.

Também foram aplicados questionários ao público que frequenta o complexo ferroviário, buscando entender sua relação com o patrimônio existente e sua percepção sobre o tombamento e intervenções neste espaço, em um total de 50 questionários. Com isto foi possível cruzar informações de diferentes pontos de vista, de frequentadores da região, sendo moradores ou não, e dos ex-ferroviários. 


\section{Capítulo 1: A Estrada de Ferro Noroeste do Brasil e Campo Grande: Bases preliminares}

Os anseios iniciais sobre a construção de uma ferrovia que ligasse o sul de Mato Grosso ao litoral brasileiro remontam a 1851. A necessidade desse empreendimento decorria de três fatores principais: o político visando a ocupação e integração dos vastos territórios despovoados situados a sudoeste do Brasil, região suscetível de ações separatistas em relação ao poder central; o econômico e de desenvolvimento que pretendia uma conectividade mais rápida entre leste e oeste, favorecendo o deslocamento de pessoas, o transporte da produção, particularmente a do café e o surgimento de núcleos urbanos, e por último, o fator geopolítico que teve como objetivo estabelecer um pólo de atração da Bolívia e do Paraguai e dos extensos territórios do sul de Mato Grosso que dependiam da via fluvial do rio Paraguai e da bacia do Prata.

O governo brasileiro defendia a necessidade de promover a modernização do país adequando-o ao capitalismo internacional sendo que para que esse projeto de modernidade fosse realmente concretizado, as autoridades governamentais deviam patrocinar a integração do território brasileiro. Foi neste contexto, que em 1904, se iniciou a construção da Estrada de Ferro Noroeste do Brasil (NOB).

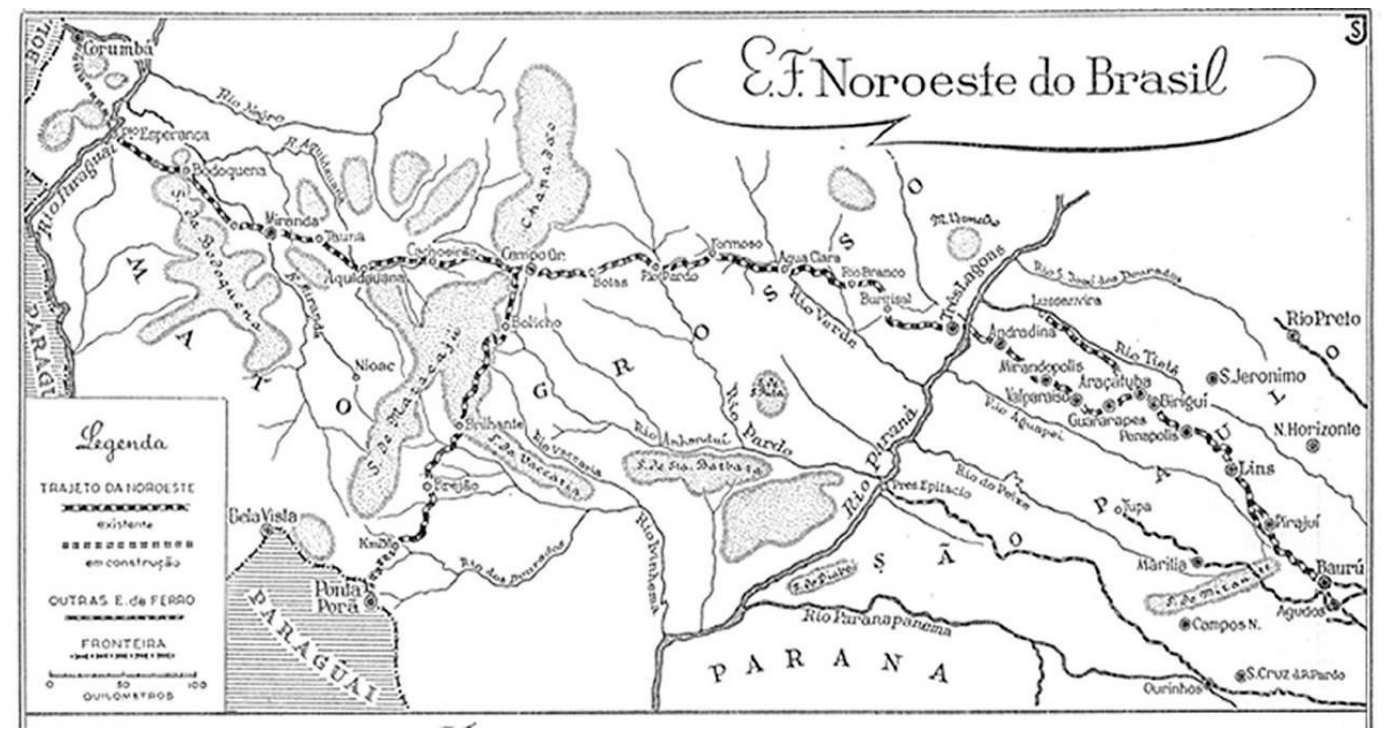

Figura 1. Mapa do Traçado da Estrada de Ferro Noroeste do Brasil. Fonte: Azevedo (1950).

Desde o fim da guerra do Paraguai (1870), a ligação de Mato Grosso as demais províncias brasileiras se dava através da navegação pela bacia do Prata que junto com a bacia do rio Paraguai, eram as principais vias de comunicação entre São Paulo, Rio de Janeiro e Corumbá ou Corumbá - Cuiabá. 
Na segunda metade do século XIX, os conflitos bélicos entre os países platinos mostraram ao governo como era vulnerável a navegação fluvial pelo Prata e não havia uma via interna rápida que ligasse Mato Grosso ao restante do país.

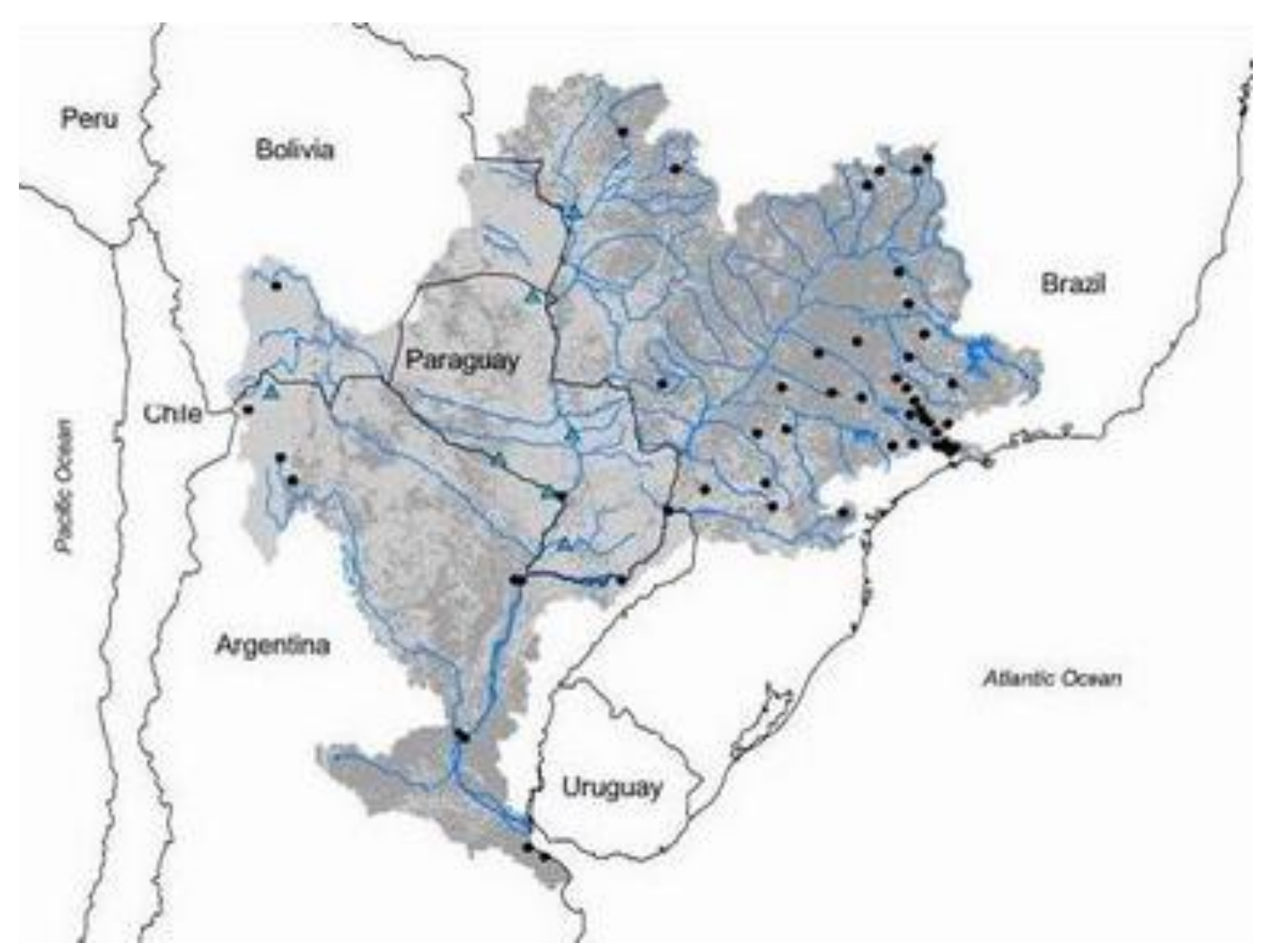

Figura 2. Mapa da Bacia do Rio Prata. Fonte:

http://www.riosvivos.org.br/Noticia/Veja+imagens+de+satelite++mapas++fotos+e+textos+sobre+a+bacia+do+rio+ da+Prata/16637, 2010.

Com isso o governo republicano idealizou a construção de uma estrada de ferro para Mato Grosso, uma vez que através dos seus trilhos teríamos uma comunicação e um transporte de pessoas, matérias-primas, e produtos industrializados de forma mais eficiente, além disso, a ferrovia vinha ao encontro do interesse do governo federal em integrar as regiões do país, modernizando-o.

Portanto, as motivações que conduziram à concepção dos projetos da Estrada de Ferro Noroeste do Brasil tinham uma dimensão nacional, de integração política, de desenvolvimento e de defesa, extravasando do quadro regional ou local, visando atingir os "padrões" do capital internacional. Naquele momento o Brasil passava por uma transformação com intuito de se tornar atrativo para o capital estrangeiro, vide as reformas sanitaristas e urbanas que ocorreram 
na então capital federal - Rio de Janeiro, promovida pelo sanitarista Osvaldo Cruz e as influências que paralelamente a modernização da capital do Brasil ocorria na elite brasileira que adotou novas condutas de comportamento, de lazer e de vestir, que se inspiravam principalmente na França, mudanças estas que foram denominadas de Belle Époque.

A proclamação da República promoveu no país um conjunto de transformações que visavam desenvolver as potencialidades econômicas do Brasil com o objetivo de tornar o país uma fronteira aberta ao capitalismo internacional. Dentro deste contexto, Rodrigues Alves, presidente da Republica em 1906, através do prefeito capital federal Pereira Passos remodelou o Rio de Janeiro, construiu avenidas largas, demoliu os cortiços existentes no centro da capital e iniciou uma política sanitária que combateu ás doenças que mais vitimavam a população carioca, como a varíola, a peste bubônica e a febre amarela. A urbanização e o saneamento do Rio de Janeiro tinham como um dos seus principais objetivos atrair investimentos estrangeiros a capital federal.

A Ferrovia Noroeste do Brasil nasceu pautada no contexto daquele momento, sendo crucial para a ligação de parte da região centro oeste com os grandes centros brasileiros de então, através do discurso de ligação e seguridade da fronteira, se adequando a necessidade de modernização dos meios de ligação do território, já objetivando atingir os padrões do capitalismo internacional, entendendo a necessidade de encurtar não só as distancias, mas também o tempo.

$\mathrm{Na}$ medida em que os trilhos eram lançados, trechos do itinerário ficavam liberados ao tráfego e as estações ou paradas ferroviárias foram instaladas. Teve uma função de penetração, alcançou novos territórios e ofereceu melhores condições para o desenvolvimento da atividade econômica e ocupação urbana, favorecendo assim a imigração as regiões pouco ou nada adensadas do noroeste paulista e do sul de Mato Grosso.

Campo Grande tem um papel importante em todo o processo de concepção, de realização operacional e de construção da NOB. Foi o ponto de encontro do traçado que se originava a Oeste em Porto Esperança (posteriormente em Corumbá) com aquele que, a Leste, partia de Bauru, sendo concretizado em 1914. A cidade também abriga um conjunto de características formais e de natureza histórica que lhe emprestam representatividade em todo o significado alargado da Noroeste do Brasil. Com a ferrovia, passou a desempenhar um papel de extrema importância na articulação dos fluxos econômicos que procediam de Corumbá, de Cuiabá e da zona cafeeira de São Paulo. 


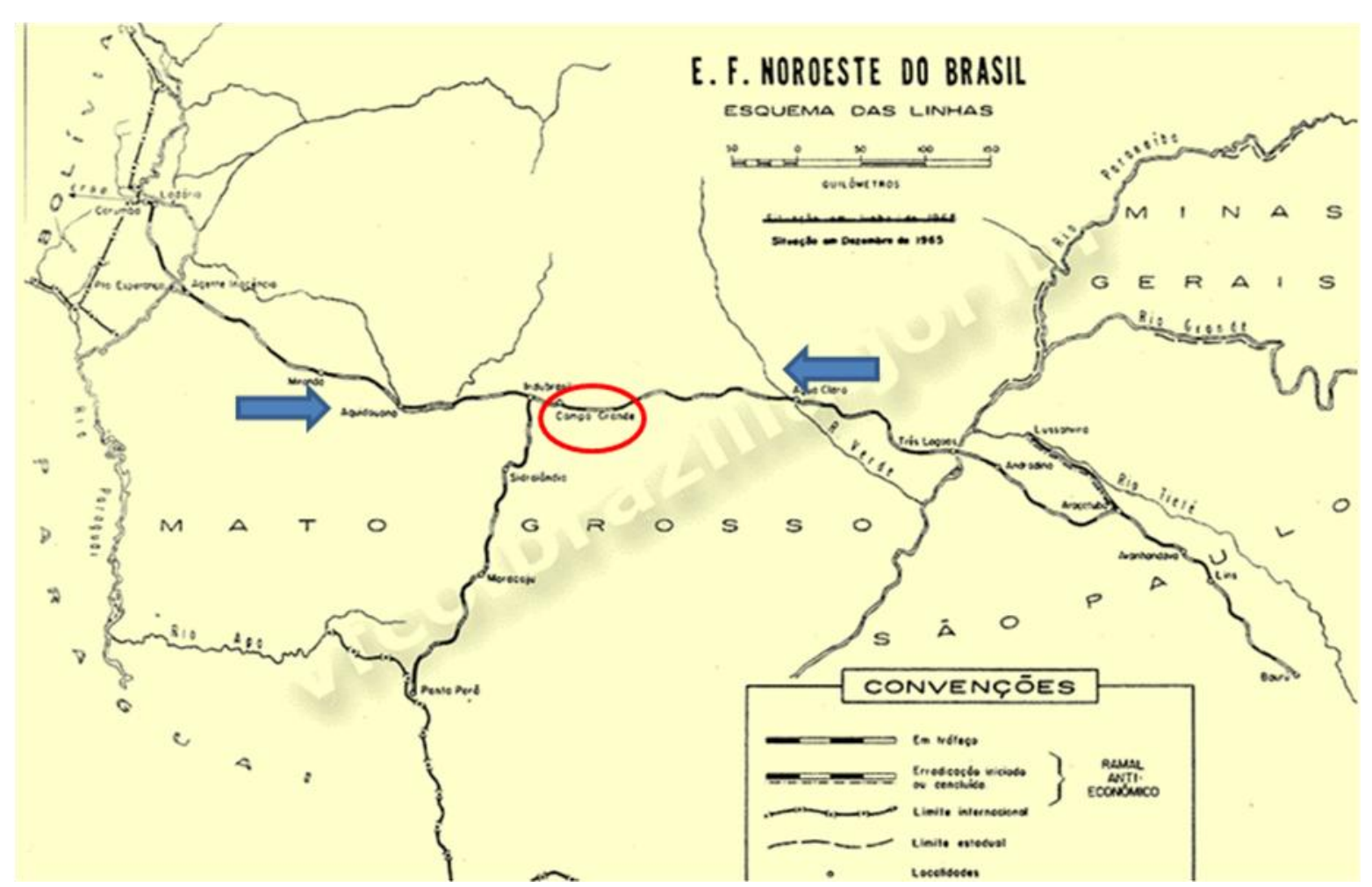

Figura 3. Mapa do Traçado da Estrada de Ferro Noroeste do Brasil, Campo Grande em destaque ao centro ponto de encontro das duas frentes de trabalho. Fonte: http://vfco.brazilia.jor.br/ferrovias/mapas/1965-Estrada-de-FerroNoroeste-do-Brasil.shtml / Organização próprio autor.

Assim, o registro histórico da NOB, do seu patrimônio cultural, material e imaterial, os trilhos, as máquinas, as edificações, as tecnologias empregadas, a compreensão de sua importância no desenvolvimento econômico e social, regional e nacional, o modelo da sua configuração urbana, reproduzido em inúmeras cidades, têm no Complexo ferroviário em Campo Grande, a mais expressiva representatividade para o patrimônio cultural brasileiro.

\subsection{Algumas considerações sobre a relação das ferrovias com o capitalismo}

As ferrovias foram instrumentos motores do desenvolvimento capitalista tendo fundamental importância em sua gênese, por facilitarem a conexão de novas áreas propicias a sua expansão durante o período da revolução industrial. A mobilidade espacial, inaugurada com este advento, trouxe um novo horizonte na busca por novas áreas de influência econômica, constituindo condição imprescindível para a difusão da economia de mercado em territórios de economia natural (LUXEMBURG, 1970), entendendo que a expansão passa a ser uma 
necessidade estrutural do capitalismo, portanto a necessidade de incorporar novas áreas é fundamental para seu desenvolvimento.

De imediato serviram de conexão do poder, de controle, pois foram a extensão orgânica do capital, transportavam os fluxos do interior ao exterior dos aglomerados europeus, foi o elo territorial das cidades naquele momento. $\mathrm{O}$ instrumento moderno que trabalhou a relação espaço tempo, sendo possível o encurtamento destas relações.

As ferrovias combateram a economia natural e desempenharam uma função de grande importância no processo de expansão capitalista, pois, tornaram-se o principal meio de ligação entre os centros de produção e distribuição de bens industrializados e os centros de formação social não capitalista, ou centros que não apresentavam um sistema capitalista desenvolvido. (BORGES, 1990, p. 23).

É importante ressaltar que o capitalismo traz em seu discurso uma intencionalidade simbólica de progresso e modernização muitas vezes disfarçada de evolução histórica interna, a qual os países periféricos proclamam cada progresso importado como uma conquista nacional, mas que, na realidade, vem exatamente destroçar a nossa relação com a natureza e impor relações desiguais. (SANTOS, 1994). Neste contexto, poderíamos afirmar que a ferrovia foi o próprio capital servindo de veículo de propagação do modo de produção capitalista, na introdução de novas formas de relações sociais e produtivas, na expansão das áreas sob a influência do sistema capitalista e na criação de novas paisagens geográficas (MATOS, 1990).

A busca pela acumulação implica na superação de barreiras espaciais. Assim, a estrada de ferro veio impor a modernização a um sistema de produção refém da modalidade de transportes praticada até sua implantação (o transporte por tropas de mulas), que era, por sua vez, muito limitada pelo tempo e pelo espaço, e que já não atendia mais as necessidades expansivistas do capitalismo. Coube então à máquina, que garantiu a integração espacial da Europa, e mudaria a história socioeconômica do Brasil, o papel de anular o espaço pelo tempo (HARVEY, 2005), proporcionado o avanço e o distanciamento da produção em relação aos centros consumidores exportadores, instaurando frentes pioneiras, criando cidades, integrando regiões, e garantindo as bases de sustentação da expansão e do desenvolvimento do modo de produção capitalista.

O século XIX representou um período histórico de significativas transformações estruturais; as nações ocidentais que se industrializaram conheceram mudanças substanciais em todos os níveis de sua organização: a burguesia, como classe social dominante, assumiu a 
hegemonia do poder político e do processo de produção social, como proprietária dos meios de produção. Foi a era das revoluções e período de afirmação do capitalismo como modo de produção dominante.

No final do século XIX, o capitalismo entrou numa fase de maior concentração da produção industrial, sendo um período econômico marcado por uma grande expansão do sistema ferroviário nas colônias europeias e nos países de economia dependente ou periférica. O capitalismo monopolista se desenvolvia e a corrida imperialista tornava-se cada vez mais acirrada entre as nações europeias, que resultou na partilha do mundo entre as nações industrializadas, consolidando sua dominação política e econômica em muitos países da África, Ásia e América Latina (BORGES, 1990, p. 25).

Desse expansionismo, que é inerente à estrutura capitalista, resulta a possibilidade de tornar estas novas regiões, inseridas no mundo capitalista, novos mercados consumidores de produtos industrializados e ao mesmo tempo áreas de captação de investimentos do capital acumulado. O capital inglês, por exemplo, já na segunda metade do século XIX, sofria constantes crises de acumulação, com fortes tendências de quedas nas taxas de lucros, tendo como uma das causas principais a falta de setores mais lucrativos para os investimentos internos. A ferrovia proporcionou aos ingleses capitalistas, além da exportação de bilhões de libras em forma de empréstimos e investimentos diretos e das exportações de bens de capital, a abertura de mercados para os bens de consumo manufaturados.

Na construção das ferrovias, ocorre a "modernização conservadora" (QUEIROZ, 1997), na qual as elites reafirmam os velhos padrões de dominação, por meio da incorporação dos símbolos da modernidade, patrocinados pelo capital internacional. A ferrovia produto da Revolução Industrial é um dos mais poderosos instrumentos da expansão capitalista servia na medida a este propósito. Ao mesmo tempo em que aceitavam sua submissão ao capital estrangeiro, às elites pregavam o discurso da defesa da soberania nacional.

A história aponta que as vias férreas sempre estiveram sob os interesses do poder econômico e político de Estados ou de grupos hegemônicos, e sempre serviram de elemento modernizador e "civilizador", porém sempre seguindo os interesses dominantes, portanto não há como se falar da história das estradas de ferro, sem relacioná-la à expansão capitalista.

A ferrovia surgiu na Inglaterra por volta do ano de 1825, estritamente ligada a Revolução Industrial, teve como intuito melhorar a conexão entre as cidades, e facilitar o transporte das 
mercadorias, proporcionando uma expansão do mercado interno abrangendo áreas que estavam isoladas do circuito comercial devido ao alto valor dos transportes.

O episódio ferroviário é uma chave importante para se conhecer a história da emergência do capitalismo mundial no século XIX. Neste período, as ferrovias foram assimiladas à ideia de modernidade, de avanço tecnológico, mecanizaram o território e se propiciaram uma mudança no modo de produção e na esfera econômica, além de simbolizar o trabalho livre e assalariado.

$\mathrm{O}$ advento da ferrovia traz consigo uma série de questões referentes ao desenvolvimento dos países que se beneficiaram deste aparato tecnológico para o fortalecimento de sua economia e força política. Ao passo que na Europa, principalmente na Inglaterra, as ferrovias significaram uma extensão de troca entre as cidades, representando o encurtamento do tempo conectando de forma mais rápida as cidades e fortalecimento da economia do país, no Brasil além do papel econômico as ferrovias tiveram importante função geopolítica, servindo com meio de penetração a áreas menos consolidadas do território nacional, portanto exerceram ampla influência na formação de diversas cidades, a partir do domínio mais efetivo sobre os territórios mais distantes dos grandes centros brasileiros.

Relata-se aqui o Brasil do final do século XIX e início do século XX, época que antecedeu o desenvolvimento industrial no país, no qual a ferrovia tinha como justificativa uma economia agroexportadora, voltada principalmente para escoamento da produção cafeeira do país rumo aos portos de Santos e Rio de Janeiro. A exportação, geradora principal da renda nacional, que se concentrava sobre o café, tinha neste período uma organização territorial específica para atender ao mercado externo. "As regiões brasileiras que tinham relações próprias com o mercado exterior, tornavam o Brasil um grande arquipélago formado por subespaços” (SANTOS 2005).

Naquele momento, a estrutura ferroviária era formada por ferrovias de pequenas extensões, entre um porto exportador e as regiões interioranas, produtoras de café, a exemplo da configuração ferroviária dos demais países sul-americanos, africanos e asiáticos, que tiveram as suas plantas ferroviárias implantadas pelos países europeus, especialmente a Inglaterra (MONASTIRSKY, 2006).

Este modelo de implantação buscava fluidez para o escoamento da produção, visando sempre a conexão com os portos, até então a questão de ligação comercial interna era mantida em segundo plano, mesmo com a formação de algumas malhas ferroviárias regionais, o foco sempre foi o escoamento da produção para fora do país. 
A construção da ferrovia possibilitou grande revolução na economia brasileira gerou maior mão de obra do para a lavoura de café resultando grande fluxo de imigração para o Brasil, encurtou o tempo de transporte da produção rumo aos portos, aumentou a capacidade de transporte e melhorou conservação do produto, resultando melhor qualidade e maiores preços no mercado internacional dando possibilidades de maiores lucros. (MONASTIRSKY, 2006).

No caso do Brasil, a ferrovia, enquanto técnica a serviço da expansão capitalista trouxe uma série de mudanças estruturais na economia e na sociedade. Foi o marco de uma grande mudança de processo na organização produtiva da economia agroexportadora, na passagem do sistema mercantil-escravocrata para a organização capitalista de produção, introduzindo uma nova tecnologia que impunha novos agentes produtivos e novas relações de produção (MARQUES, 2009).

As ferrovias possibilitaram a ampliação das fronteiras para formação de novas cidades, e serviram de suporte econômico para produção agrícola e atividades pecuárias, principalmente nos cultivos do café, que foi base da economia brasileira até meados da década de 1930. Com a expansão das relações capitalistas de produção, tornaram-se indispensáveis à incorporação de novas áreas à economia mercantil, ampliando as relações de dependência a nível nacional. A ferrovia foi responsável pela ocupação e inserção de novas áreas na economia de mercado, sendo desta forma responsável também pela expansão e adensamento geográfico em várias regiões no Brasil.

O surgimento das estradas de ferro no Brasil esteve ligado à necessidade de modernização do processo de produção dependente, com a finalidade de ajustá-lo ao capitalismo em expansão. O crescimento ferroviário acompanhou o processo de transformação da economia brasileira, servindo à expansão da produção agroexportadora e, a partir das primeiras décadas do século $\mathrm{XX}$, serviu também de suporte ao avanço das frentes pioneiras na expansão das fronteiras internas do capitalismo, proporcionando penetração em áreas passiveis de disputas territoriais com países vizinhos.

As linhas férreas possibilitaram e aceleraram o desenvolvimento das lavouras em várias direções, superando em muito a área até então restrita pela operacionalidade das tropas de mulas. Outra articulação que as ferrovias também estimularam foi o deslocamento da produção pelos grandes portos (Rio de Janeiro e Santos), em detrimento dos portos menores, significando o fortalecimento das regiões mais habitadas no país naquele momento. 
A marcha do café, por sua vez, aumentou a concentração da propriedade fundiária, na valorização da terra e na eliminação da pequena e média produção. O processo de industrialização emergente se beneficiou largamente com este crescimento da economia cafeeira, tanto pelo capital acumulado no setor (que poderia ser investido na produção industrial), como pela ampliação do mercado interno para os manufaturados e o crescimento do exército industrial de reserva. Ao contrário da acumulação do setor agrário, que estava assentada na expansão do mercado externo, a acumulação do capital industrial estava essencialmente baseada no desenvolvimento do mercado interno.

Contudo, o surgimento da ferrovia no Brasil vai além da escoação do café e da busca por novos mercados internos, ela foi legitimo instrumento de penetração, de delimitação e seguridade territorial, tendo como consequência a formação de aglomerações e posteriormente cidades, sendo que a partir dos territórios "conquistados", novas relações surgiram, vilas e distritos ganharam força econômica e ao longo dos anos fortaleceram o território até então isolado do resto do país.

De fato, as ferrovias aceleraram o processo de modernização do país, provocando alterações no sistema produtivo, beneficiando tanto o comércio das regiões cafeeiras como o comércio de produtos industrializados europeus. Havia, nas cidades assistidas pela ferrovia, diversificação e efervescência econômica e cultural, que não se reproduzia da mesma forma além do alcance dos trilhos. Este quadro mudou a partir do momento em que a ferrovia passa a exercer seu papel de penetração, ligando áreas antes isoladas aos importantes centros do Brasil naquele momento.

Desde a sua implantação no Brasil, a ferrovia contribuiu para o desenvolvimento econômico do país, foi um dos alicerces para a integração territorial, auxiliou os processos de urbanização e industrialização, foi decisiva nas transformações urbanas das cidades ferroviárias e influenciou a sociedade, tendo, além disso, importante significado cultural, pois junto às cidades influenciou o cotidiano, criando uma identidade as regiões ferroviárias.

A partir do momento em que a técnica avançou, a malha ferroviária se tornou coadjuvante, sendo superada pela dinâmica do transporte rodoviário, que "libertou" o desejo pelo desconhecido, quebrando a rigidez do traçado do transporte ferroviário. 


\subsection{Ferrovias e Brasil: Um breve histórico}

Antes da construção das ferrovias, a comunicação no interior do país encontrava grandes dificuldades, em sua maior parte por conta das longas distâncias, além do relevo peculiar, das matas densas e rios sinuosos com fortes correntezas.

Ao longo da costa brasileira a navegação marítima era responsável pela comunicação. Já a navegação fluvial, apesar da grande dificuldade em vários trechos, devido à presença de saltos e corredeiras, foi importante na ligação do sudeste e do sul com as capitanias de Goiás e Mato Grosso, por meio dos rios Tietê e Paraná e seus afluentes. No século XVIII, esta ligação chega ao extremo norte, por meio dos rios Tocantins, Araguaia, Tapajós e Madeira. Nessa mesma época, é instalado um caminho ligando o Rio Grande do Sul a São Paulo, que se tornou muito importante, pois passa a conectar a extremidade meridional do país ao seu sistema de comunicações e transporte.

De acordo com Prado Júnior (1998), os percursos disponíveis até o século XIX eram, em sua maioria, muito extensos e dificultosos, chegando a atingir milhares de quilômetros e consumindo meses de viagem. Era o caso, por exemplo, das ligações entre São Paulo e Mato Grosso, onde se fazia necessário percorrer grande extensão dos rios Tietê, Paraná e vários rios da bacia do Paraguai, para se alcançar Cuiabá que era então o centro e capital da região mineradora de Mato Grosso. Os estreitos caminhos de terra, na época das chuvas, transformavam-se em lamaçais intransponíveis. O transporte de mercadorias se fazia praticamente todo ou no dorso de animais, ou carregados por escravos, o que fazia com que as viagens levassem muito tempo para completar o deslocamento entre pontos mais distantes.

Neste contexto a construção de ferrovias surge como meio que facilitaria a comunicação entre as principais cidades do Brasil que já tinham grande adensamento populacional, e serviria também para consolidação do território nacional, sendo que ainda na época imperial foram traçados os primeiros planos de ferrovias do Brasil.

As primeiras tentativas de implantação ferroviária no Brasil tiveram início com o Decreto Imperial $\mathrm{n}^{\mathrm{o}} 101$ de 31 de outubro de 1835. Tinha como objetivo conceder privilégios que viabilizassem a construção de linhas férreas que ligassem a capital do Império às capitais das províncias da Bahia, Minas Gerais e Rio Grande do Sul. Esse decreto garantia à companhia ferroviária interessada na construção destas linhas férreas a exclusividade pela sua exploração por um prazo mínimo de quarenta anos: 
Art. $4^{\circ} \mathrm{O}$ Governo fica autorisada (sic) a conceder a uma ou mais Companhias, que fizerem uma estrada de ferro da Capital do Rio de Janeiro para as de Minas Gerais, Rio Grande do Sul, e Bahia, carta de privilégio exclusivo por espaço de 40 anos para o uso de carros para transportes de gêneros e passageiros. (Decreto $n^{\circ} 101$ de 31/10/1835).

Em 27 de Abril de 1852, a Presidência da Província do Rio de Janeiro, contratou Irineu Evangelista de Souza, para a construção de uma via férrea, que partindo do Porto de Mauá, fosse até a Raiz da Serra de Petrópolis. Esta foi a primeira ferrovia construída em terras brasileiras, a Imperial Companhia de Navegação a Vapor e Estrada de Ferro de Petrópolis, mais conhecida como Estrada de Ferro Mauá (ANPF, 2003).

O Decreto do Governo Geral N . $^{\circ} 987$ de 12 de Junho de 1852, concedeu-lhe o privilégio por 10 anos, para a navegação a vapor entre a Côrte (Rio de Janeiro) e o Porto de Mauá e já no dia 29 de Agosto do mesmo ano, na localidade de Fragoso, Distrito de Inhomirim, foram inaugurados os trabalhos de construção da ferrovia, com a presença do Imperador e outras autoridades, trabalhos estes que foram conduzidos pelos Engenheiros ingleses William Bragge, Roberto Milligan (a quem coube a execução da Planta da Estrada) e Joseph Cliffe (ANPF, 2003).

Segundo Oliveira (2005, s/p):

Para levar a efeito o projeto, em 29 de maio do mesmo ano, na sede do Banco do Brasil no Rio de Janeiro, foi fundada a Imperial Companhia de Navegação a Vapor e Estrada de Ferro de Petropolis, com capital de 2 mil contos de Réis, divididos em 10 mil ações de duzentos mil réis cada. Irineu subscreveu pessoalmente um terço das ações e, pelos estatutos, foi nomeado Presidente da Companhia. Em 30 de abril de 1854, com a presença da Comitiva Imperial, foi inaugurada a Ferrovia no trecho de 14,5 kms entre Mauá e Fragoso. Nesta oportunidade, o Imperador conferiu a Irineu Evangelista de Souza o título de Barão de Mauá ${ }^{\text {. }}$

Devido ao rápido crescimento do comércio de café e às dificuldades que os caminhos existentes impunham ao modelo agroexportador, desde as primeiras décadas do século XIX, o governo imperial mostrava interesse na construção de uma rede ferroviária. Havia tanto

${ }^{1}$ http://www.anpf.com.br/historianostrilhos10_novembro2003.htm - Acesso em janeiro de 2013. 
interesses econômicos, de escoamento de nossa produção agrícola, quanto estratégicos, de defesa de nossas fronteiras. No entanto, a situação financeira do país se encontrava comprometida pela dívida externa. De acordo com Prado Junior (1998), nossa emancipação política já começa com uma crescente dívida externa provocada pela vinda da corte portuguesa ao Brasil em 1808. Na metade do século XIX, o serviço da dívida já consumia $40 \%$ do total da receita do país. Além do volume da dívida, a guerra contra o Paraguai havia deixado as finanças do país profundamente comprometidas e, dessa forma, a participação do governo na implantação das ferrovias limitouse aos incentivos. $\mathrm{O}$ capital a partir deste momento seria oriundo da iniciativa privada.

É importante ressaltar que no Brasil o desenvolvimento ferroviário passou, por duas etapas distintas dentro do processo de inserção da economia nacional no complexo econômico capitalista mundial. Na primeira etapa, ou seja, até o final do século XIX, acompanhou quase exclusivamente a economia agroexportadora, ligando os centros produtores aos portos de exportação. Em um segundo momento, a partir das primeiras décadas do século XX, as ferrovias passaram a servir também como vias de expansão das ralações capitalistas de produção, buscando novas áreas de influência fomentando a expansão das áreas industriais e, portanto da própria urbanização.

O capital estrangeiro (principalmente inglês) sob a responsabilidade de elementos estrangeiros e nacionais ligados aos interesses metropolitanos e às oligarquias nacionais que controlavam os setores agroexportadores tiveram um papel fundamental na implantação dos troncos ferroviários no Brasil, principalmente aqueles mais economicamente estratégicos, como a São Paulo Railway, por exemplo, que, financiado pelo capital inglês, em pouco tempo assumiu o monopólio dos transportes do café paulista ao porto de Santos. Isso mostra que a expansão capitalista, geneticamente, possui um centro difusor, que comanda todo movimento do sistema. (MORAES, 2000).

É importante lembrar que no decorrer da história da estrada de ferro no Brasil, o capital estrangeiro só se manteve exclusivamente presente enquanto a ferrovia foi objeto de lucro, a partir do momento que isso mudava eram estatizadas.

O papel das ferrovias no Brasil teve influência do modelo trazido da Europa, principalmente na Inglaterra, que teve a locomotiva a vapor como um marco na revolução industrial, podendo transportar grande quantidade de carga em sua composição e assim ligar os grandes centros servindo de principal meio de abastecimento das cidades. No Brasil, após o 
período do café, as ferrovias eram vistas como novos meios de expansão de mercado, sendo utilizadas para transporte de produtos industrializados e trabalhadores, além do gado de corte, e a conexão com centros mais desenvolvidas neste momento, com como no caso da construção da Estrada de Ferro Noroeste do Brasil, que tinha dentro de suas outras importantes funções o abastecimento do mercado de São Paulo com o gado manejado no então Mato Grosso.

A ferrovia NOB, apesar deste papel importante na dinâmica capitalista, teve importante significado ao transpor o oeste brasileiro, de forma sistêmica foi "costurando" o território, povoando os vilarejos, "dominando" áreas já pertencentes ao Brasil. Sua construção ocorre em período muito importante, no pós-guerra com o Paraguai, e de certa forma traz na sua intencionalidade a prevenção de um novo conflito, visto que neste momento a Argentina estava cooptando forças, e uma grande porção de terra desprovida de conexões com o restante do Brasil poderia facilmente ser "conquistada".

Em linhas gerais a construção das ferrovias no Brasil, além de atender a demanda capitalista da época que privilegiava o escoamento da produção rural rumo aos portos, teve importante função ao legitimar o território nacional através de sua consolidação dada pelos trilhos que avançavam rumo a áreas distantes dos grandes centros. Este fato evidencia o importante papel da ferrovia na delimitação geopolítica do país, que possibilitou a conquista do oeste, propiciando o surgimento de cidades ao longo do seu traçado.

\subsection{A Construção da Estrada de Ferro Noroeste do Brasil: entre objetivos e fins}

A construção da ferrovia Estrada de Ferro Noroeste do Brasil é tida como um marco para o atual estado de Mato Grosso do Sul, na época da construção, estado do Mato Grosso. A ferrovia trouxe um aquecimento econômico além de grandes fluxos imigratórios, pessoas chegavam de diversas partes do Brasil, assim como da Itália, Espanha, Portugal, Síria, e Líbano e Japão. A espera foi longa e demorada, os trilhos saíram de Bauru no interior de São Paulo visando chegar até Corumbá. A obra foi concluída em etapas, e trazia consigo a conexão do então longínquo interior do Mato Grosso com São Paulo, abrindo mais ainda as fronteiras com o resto do país.

O Brasil neste momento vivia sob a política da República Velha, também chamada de política do café com leite, pela alternância no poder de representantes das oligarquias de Minas

ou São Paulo. Priorizava-se neste período o modelo agrário exportador, mesmo com a industrialização em curso, fato este o que desagradava os industriários naquela época. 
Predominou as exportações de café, base da economia e maior fonte de receita tributária. Foi também um período de modernização, com grandes surtos de industrialização, porém, a economia continuaria dominada pela cultura do café, até a Quebra da Bolsa de valores de Nova Iorque, durante a Crise de 1929.

Durante a segunda metade do século XIX, até a década de 1930 no século XX, o café foi o principal produto de exportação brasileiro. As dívidas provenientes desta exportação contribuíram para o início do processo de industrialização a partir de 1870. Por volta de 1895, a economia cafeeira passou a mostrar sinais de crise. As causas desta crise estavam no excesso de produção mundial. A oferta, sendo maior que a procura, acarreta uma queda nos preços prejudicando os fazendeiros de café. Entre a alternância dos governantes, o avanço industrial foi incentivado por Prudente de Morais em 1894, e freado por Campos Sales em 1898 sob a alegação que o Brasil era um país agrícola, atendendo assim os interesses das oligarquias rurais. O apoio à expansão industrial foi retomado em 1902 com Rodrigues Alves que teve seu governo marcado pelo surto progressista e pela economia da borracha.

Neste contexto inicial, os motivos que levaram a construção da NOB foram diversos e dentro deles estava à necessidade de maior conexão e proteção das fronteiras, discurso este que vinha desde 1870 após a guerra do Paraguai, visto que o mais importante meio de comunicação com o resto do Brasil era via navegação pela bacia do rio Paraguai. Além do interesse no resguardo do território, a província de Mato Grosso era vista como importante produtor pecuarista, e a construção da estrada de ferro seria muito importante para o escoamento desta produção em direção aos mercados consumidores.

A construção da ferrovia NOB também teve importância para consolidação do território nacional, pois o Brasil ainda defendia seus limites territoriais pós-guerra do Paraguai, além disso, o Brasil temia a tentativa de imperialismo regional por parte da Argentina, que cooptava economias menores para sua zona de influência. Essas questões faziam com que o governo tivesse interesse em garantir o domínio efetivo sobre o território conquistado.

Em plano Nacional, a NOB seria um braço que viria a conectar o porto de Santos, como o Oceano Pacífico na cidade de Arica no Chile, sendo ramificada a partir da importante ferrovia Sorocabana, rumando em direção a Cuiabá, capital do Mato Grosso. Traçado este posteriormente alterado para a cidade de Corumbá, na divisa do Mato Grosso com a Bolívia, importante porto fluvial daquela época, hoje pertencente ao estado do Mato Grosso do Sul. 
Esta preocupação do Governo Nacional tinha como motivo a sua consolidação como potencia na América do Sul e a seguridade de seu vasto território, visto o Brasil e a Argentina viviam um contexto de polarização de influência, sendo o "encurtamento" entre o porto de Santos e o oceano Pacífico um ponto favorável ao Brasil.

No plano regional, a ferrovia teve um significado, além do explicitado no plano Nacional, mais "romântico", pois levou além do desenvolvimento econômico a abertura com os grandes centros Nacionais, de forma que trocas culturais também fossem possíveis, colocando a cidade de Campo Grande no cenário nacional como importante centro ferroviário do país.

Em 1904 foi criada a Companhia Estrada de Ferro Noroeste do Brasil - CEFNOB, e assinado o termo de concessão para a construção da ferrovia. A Companhia Paulista percebeu que a nova rota acabaria desviando o tráfego diretamente para Minas Gerais e Rio de Janeiro, passando fora do estado de São Paulo, o que seria prejudicial aos seus negócios. Assim, sob seu patrocínio, o Clube de Engenharia do Rio de Janeiro divulgou parecer técnico, sugerindo que a nova ferrovia deveria partir da então vila de São Paulo dos Agudos (localidade já alcançada pelas linhas tanto da Paulista quanto da Sorocabana), e com destino a Cuiabá.

Como o traçado da Sorocabana (Figura 4) já estava perto de alcançar a vila de Bauru decretou-se então que a NOB deveria partir dos trilhos da Sorocabana em direção a Cuiabá. O que abriria a possibilidade de ligação entre os oceanos Atlântico (Santos-SP-Brasil) e Pacífico (Arica - Chile), passando pela Bolívia, conforme o mapa abaixo (Figura 5). 


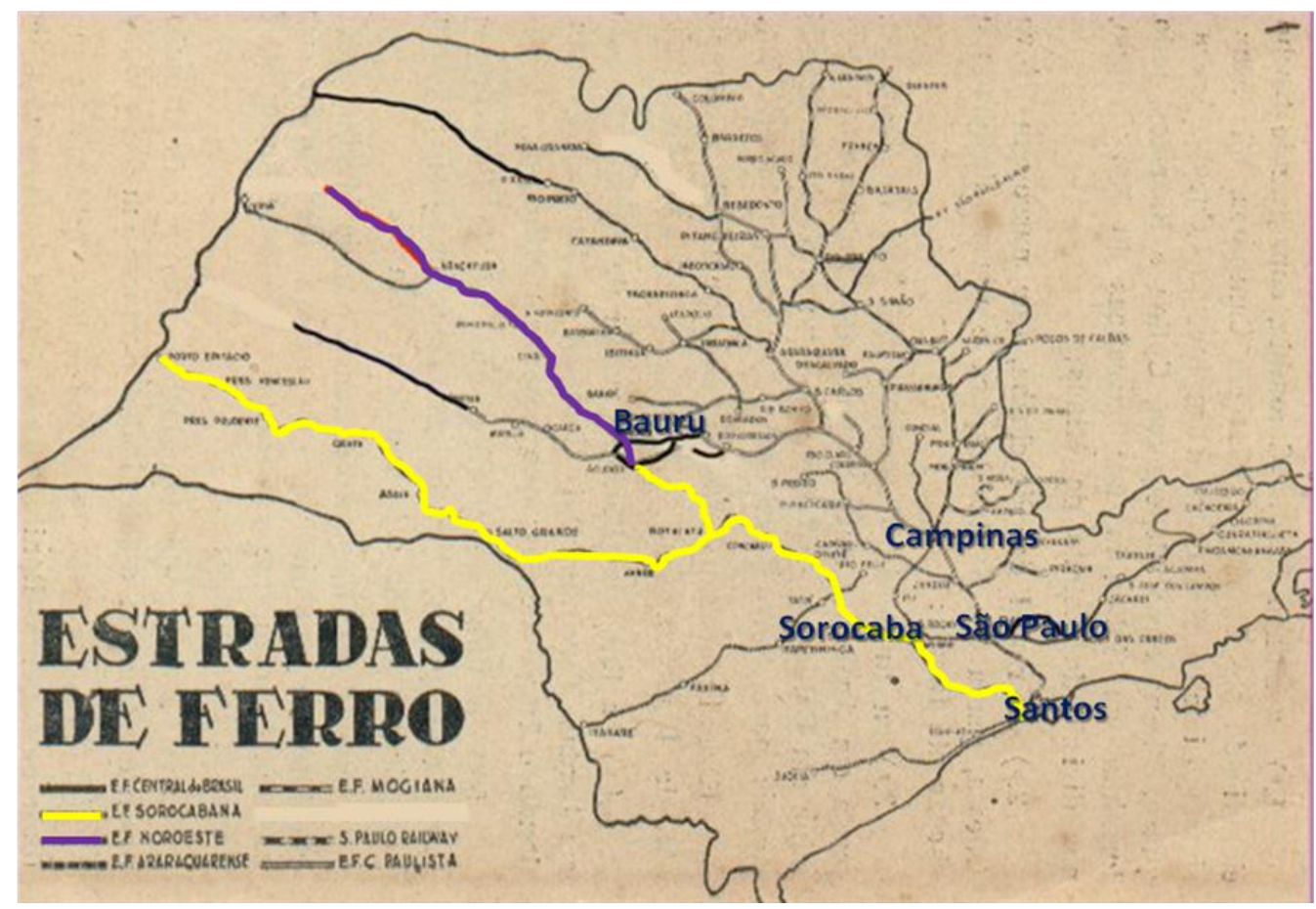

Figura 4. Mapa Ligação Sorocabana e http://www.estacoesferroviarias.com.br/j/jacarecatinga.htm, acesso em abril de 2014. Organização próprio autor. 


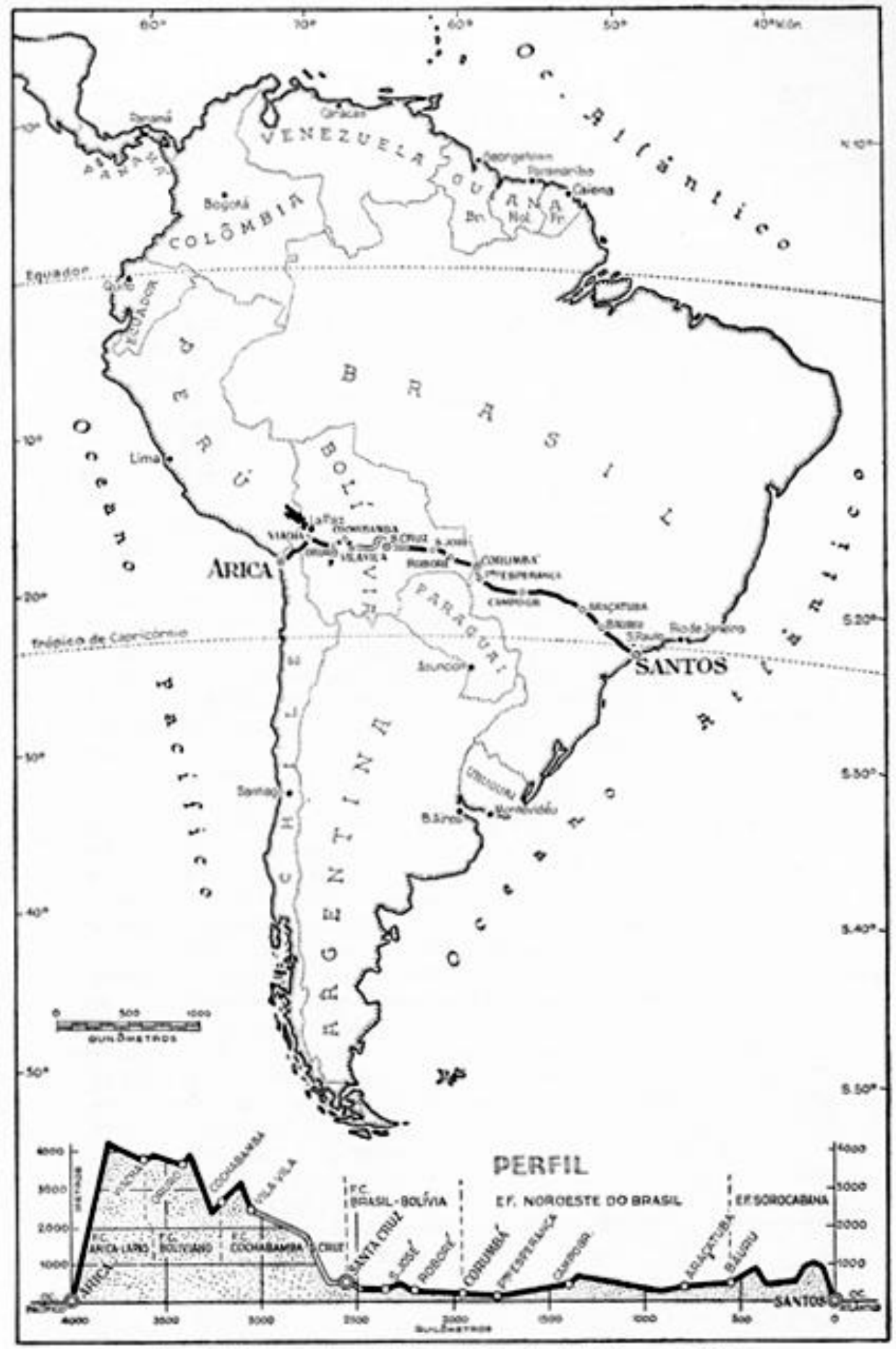

Mapa da Transcontinental Santos-Arica. Do Atlintico ao Padifico.

Figura 5. Mapa do Traçado Atlântico - Pacífico. Fonte: Azevedo (1950).

Desta forma a NOB se ligaria de forma estratégica a Sorocabana, em Bauru tendo uma importância geopolítica, visto que Brasil e Argentina viviam num contexto sul-americano de 
polarização de influências regionais e crucial a atração dos vizinhos Paraguai e Bolívia (esta especialmente), representada por uma conexão entre Atlântico e Pacífico. Isso de fato não aconteceu de forma efetiva, tendo a conexão final na Cidade de Corumbá que por sua vez se conectava a estrada de ferro Brasil-Bolivia com destino final em Santa Cruz de La Sierra.

A Estrada de Ferro Sorocabana, foi fundamental para o desenvolvimento das cidades do oeste paulista, teve seu inicio voltado ao transporte de algodão, porém foi com o transporte de café que consolidou sua importância. Sua ligação com a NOB traria a possibilidade de conexão entre um amplo mercado, pois faria conexão, a principio, com os oceanos Atlântico e Pacifico.

Mesmo com o traçado pretendido não sendo atingido plenamente, a ligação entre Santos e Corumbá, por meio da conexão destas ferrovias foi muito importante para o escoamento do café paulista.

Em 1907, o destino da concessão federal sobre o trecho da NOB foi novamente modificado de Cuiabá para o porto fluvial de Corumbá, estendendo o traçado da ferrovia até a divisa com a Bolívia. Em 1908, a concessão foi dividida em duas partes: a primeira entre Bauru e Itapura (próximo à foz do Rio Tietê), e a segunda entre Itapura e Corumbá. A primeira parte não se alterou. Já a segunda passou a figurar juridicamente como domínio da União, embora devesse ser construída pela própria Companhia CEFNOB e arrendada à mesma por sessenta anos.

Em 1913, o governo reiterou a posse do trecho já construído pela CEFNOB e a ferrovia passou a ficar totalmente sob domínio do governo federal. Em 1914 as duas frentes de trabalho se encontram na cidade de Campo Grande na estação de Ligação, que recebeu este nome justamente pela conexão das duas frentes de trabalho. As obras, no entanto, permaneceram paradas em Porto Esperança, às margens do rio Paraguai até 1952, quando é concluído o trecho até Corumbá. No ano seguinte, é concluído o ramal Ponta Porã.

Ainda sobre a construção desta ferrovia, especula-se que muitos interesses privados estavam presentes na sua construção, segundo Queiroz (2004), a empresa Brazil Land and Cattle Packing, que era proprietária de grandes fazendas nas cidades de Campo Grande e Três Lagoas e utilizava a ferrovia para transportar gado de corte para seu matadouro, em Osasco/SP. Estas fazendas e a empresa citada pertenciam ao espólio de Percival Farquhar, que, por sua vez, articulava seus negócios por meio do engenheiro João Teixeira Soares, um dos fundadores da Noroeste. Mais tarde, Soares passa a figurar como sócio de algumas empresas de Farquhar, que 
abrangiam tanto empreendimentos para construção de obras na ferrovia, quanto o ramo de armazéns e frigoríficos.

Ainda de acordo com Queiroz (1997), o trecho final da ferrovia, atendia aos interesses dos paulistas, para aproveitamento do gado de Mato Grosso, aos do governo federal, na defesa de suas fronteiras e também aos interesses dos dirigentes e da elite mato-grossense. Muitas vezes, esses interesses se mesclavam, pela função que assumiam alguns membros da elite. É o caso de Francisco Glicério, que além de líder do governo Rodrigues Alves no Senado, foi acionista e procurador do Banco União de São Paulo, um dos beneficiários da primeira concessão para construção da Noroeste. Foi também o relator do Tratado de Petrópolis, assinado com a Bolívia, que resultou na construção da ferrovia Madeira-Mamoré.

É perceptível que mesmo assegurando a posse do território, o jogo de interesses por trás da construção da NOB, aponta que se pensava em novos mercados, e a possibilidade de criação de novos polos para o desenvolvimento capitalista, atendendo a desejos de elites locais e de São Paulo, pois ao longo do traçado da ferrovia foram se criando vilas e cidades, com potencial tanto de consumo como de produção industrial, desta forma a expansão capitalista chegaria ao campo, se conectando com o mercado rural agropastoril.

Entende-se então, que a NOB, assim como outras ferrovias, tiveram importante função no processo expansionista da economia de mercado, na medida em que se tornaram o principal elemento de ligação entre os centros produtores ou distribuidores de produtos industrializados e as formações sociais não capitalistas, onde a mais-valia é realizada e capitalizada, e ainda como meio de escoar a produção primária, alimentos e matérias-primas exigidas pelas grandes indústrias (MARQUES, 2009).

Desta forma, a construção da Estrada de Ferro Noroeste do Brasil pode ser destacada como fator decisivo na consolidação econômica, demográfica e social do sul do Estado de Mato Grosso. A NOB impulsionou fortemente o fluxo migratório, permitindo a implantação de um importante pólo agropecuário e de industrialização. Possibilitou ainda o fortalecimento de vários municípios ao longo de seu traçado, bem como o aumento gradativo da importância da cidade de Campo Grande (MS), tendo como impactos mais visíveis deste processo de transformações, a sua consolidação em uma área de atração de investimentos e de contingentes populacionais provenientes das mais diversas regiões do Brasil e dos países vizinhos (TRUBILIANO; JUNIOR, 2007). 


\subsection{A NOB e Campo Grande: Nas entrelinhas da História}

Entre 1900 - 1930, Campo Grande já dava seus primeiros passos em direção à modernização da estrutura de seu assentamento e, para tanto, contribuíram além da estrada de ferro, a pecuária bovina, a instalação dos quartéis, a chegada dos primeiros engenheiros e arquitetos que, aliadas às condições econômicas, faziam de Campo Grande uma cidade com características diferentes das demais do oeste brasileiro, e essas diversas manifestações contribuíram para o arranjo da arquitetura moderna no município (ARRUDA, 2000).

Em 1905 começam os estudos em Campo Grande para definir o traçado da ferrovia com a chegada, do engenheiro Emílio Schcnoor e sua comitiva que estavam a serviço a serviço da CEFNOB.

Weingartner (1995) escreve que o contrato assinado entre o governo federal e a Companhia de Estrada de Ferro Noroeste do Brasil, permitia à companhia interferir na estruturação de áreas urbanas, elaborando um planejamento para disciplinar a ocupação daquelas cidades situadas no traçado ferroviário, sugerindo às intendências municipais um código de postura, no qual, além de estabelecer diretrizes de ocupação, definia algumas medidas de higiene e saúde pública. Estas medidas sugerem o interesse de modernização dos aglomerados urbanos por parte do Governo Federal, em um movimento influenciado pelo capital estrangeiro.

Com isso, as cidades ganham um traçado xadrez onde, além de reordenar a aglomeração existente, prevê a expansão urbana (Figura 6).

Este planejamento urbano descreve a influência que a NOB exerce sobre o arranjo urbano central de Campo Grande, estabelecendo um centro onde se localizam: o comércio, as residências, os órgãos públicos, os órgãos do complexo ferroviário e, na periferia, alguns bairros residenciais.

Este processo de planejamento urbano foi adotado em todas as cidades que nasceram no leito da via férrea. A configuração urbana de Campo Grande, até 1905 um povoado dedicado principalmente ao comércio de gado, segue, a partir de 1914, ou um pouco antes, o traçado sugerido pelos técnicos da Companhia de Estrada de Ferro Noroeste do Brasil. 


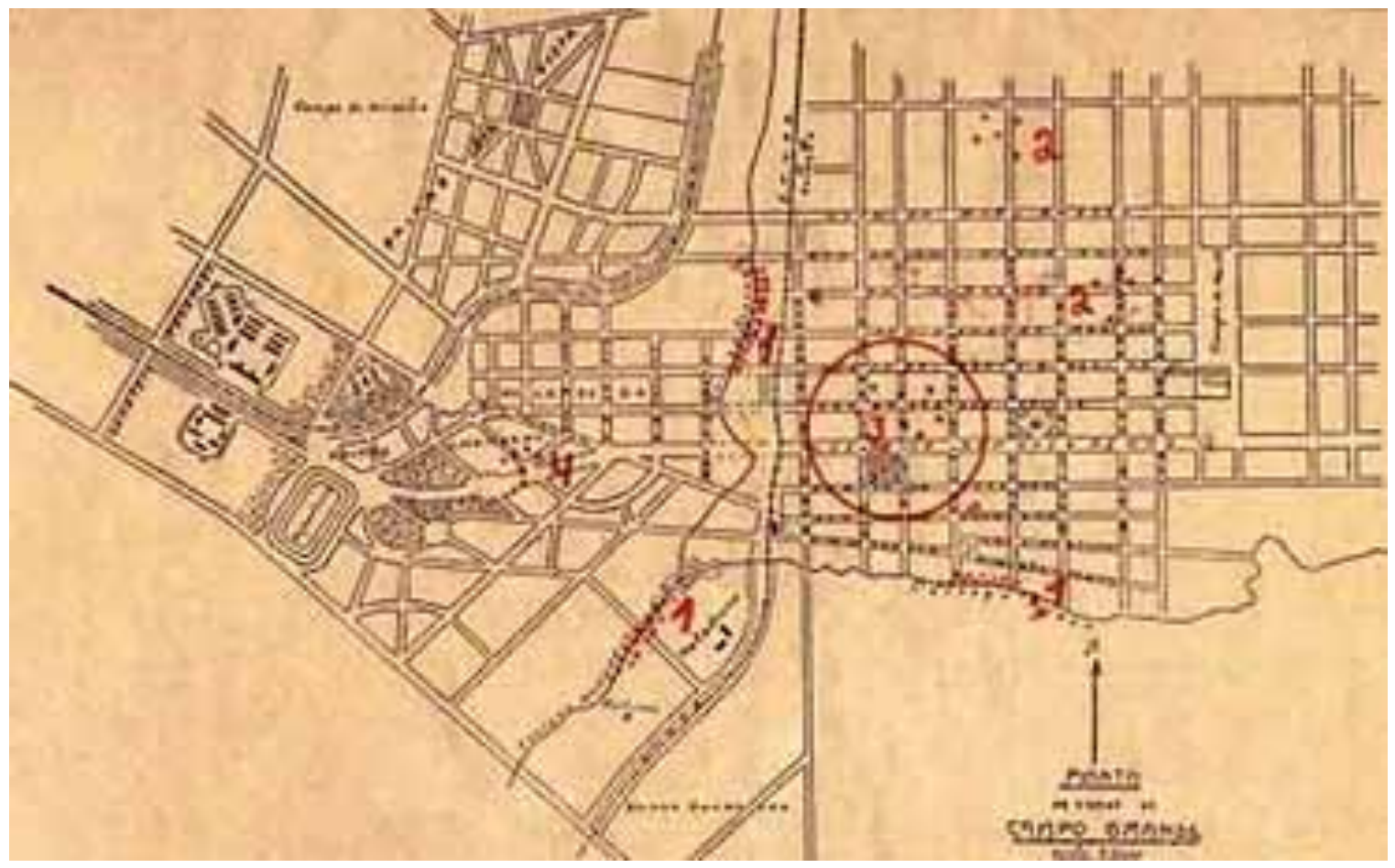

Figura 6. Planta do traçado urbano de Campo Grande em 1939. Fonte: Arruda (2009).

Entende-se que Campo Grande atendia os requisitos econômicos e estratégicos que a NOB tinha como objetivo naquele momento, pois possuía localização estratégica, sendo caminho para a fronteira com Paraguai e Bolívia. Com a ferrovia, passou a desempenhar um papel de extrema importância na articulação dos fluxos econômicos que procediam de Corumbá, de Cuiabá e da zona cafeeira de São Paulo.

Até então na cidade levava-se um ritmo de vida pacato, comum em uma cidade do interior daquele momento, a ferrovia provoca um intenso movimento de imigrantes e migrantes, sendo estes os trabalhadores da própria ferrovia. Eles vêm para atender os diferentes serviços e de acordo com os interesses dessa companhia alguns funcionários permanecem definitivamente na cidade, outros são remanejados. Este intercâmbio permitia constante renovação de ideias, porque estes funcionários se envolvem com a vida socioeconômica e política da cidade e do Estado.

A NOB trouxe facilidade na exportação da produção de gado e madeira, além de realizar a importação dos produtos industrializados, fazendo com que ocorresse uma expansão no comércio local, gerando forte movimento financeiro em Campo Grande. Toda esta movimentação de pessoas e econômica produziu um novo ritmo de vida na cidade, com forte influência da ferrovia que movimentava a região central da cidade, conduzindo assim um novo ritmo de vida. 
Neste passo a cidade começa a se tornar referência na região, após a regularização das viagens ferroviárias, Campo Grande gradativamente centraliza na região, as principais atividades econômicas e políticas. Esta sua condição de entreposto comercial lhe deu o status de pólo irradiador de ideias, ultrapassando Corumbá neste momento enquanto cidade mais importante do sul de Mato Grosso.

Com isso entende-se que as ferrovias possuíram outros significados além do econômico, alterando a vida de todos, no caso de Campo Grande a chegada da NOB, trouxe uma ruptura no modo de vida, um novo momento à cidade, momento este hoje interpretado pela memória oficial dos donos de terras. A historia oficial sobre o desenvolvimento da cidade elevou ao cargo de heróis os detentores de capital, que investiam na cidade e dela tiravam seu lucro, porém questiona-se sobre os anônimos, os que a sombra dos relatos históricos, viveram, produziram e construíram a cidade na época da chegada da NOB. A ferrovia passou a fazer parte do cotidiano de vida na cidade, segundo Carlos (2001) através das práticas socioespaciais o espaço ganha significado, com isso entende-se que a estação representa um novo paradigma, através dela tudo chega e por meio dela e tudo se vai, é um lugar de encontros e despedidas.

Ainda sobre as transformações que a ferrovia trouxe a Campo Grande, segundo Arruda (1991) os trilhos da ferrovia criaram ou consolidaram uma espécie de divisão simbólica do espaço urbano da cidade, revelando outros impactos com a chegada da NOB, como a divisão da cidade entre o lado de baixo e o lado de cima dos trilhos. O lado de baixo era conhecido como a parte pobre da cidade, o contrário do lado de cima que respirava ares mais "pomposos", com atividades mais nobres, bairros mais estruturados que garantiam melhores condições de vida.

Entende-se com isso que a ferrovia trouxe consigo além do desenvolvimento, os problemas que acompanham este fenômeno, e de pacata vila interiorana a cidade passa a lidar com as contradições presentes em cidades maiores e com maior expressão naquele momento no país. Junto com a divisão espacial a ferrovia trouxe o ritmo de produção capitalista, que neste momento faria profunda mudança no ritmo de vida de Campo Grande, podendo-se afirmar que o modelo de produção capitalista era antagônico ao modo de vida disperso na cidade e suas próprias representações internas de tempo e trabalho foram alterados.

A produção capitalista gera esta imposição e consequente supressão, novas memórias sempre sobrepuseram outras mais antigas, pois o espaço é um acumulo de tempos desiguais (SANTOS, 1980), neste sentido a ferrovia alterou sim o espaço até então vigente, pois trouxe a 
modernização, através de um novo padrão urbanístico e também de relações sociais e de trabalho, criando um novo marco simbólico para Campo Grande.

Conclui-se que o processo de consolidação da NOB, trouxe transformações importantes a Campo Grande, como um novo padrão na sua formação espacial, onde os trilhos concentravam as referencias para formação dos bairros, novos movimentos de trabalho, inclusive inseriram o processo de divisão do trabalho assalariado da forma que conhecemos hoje.

Entendendo que o processo ferroviário foi um marco importante para o crescimento de Campo Grande, que se desenvolvia a passos rápidos funcionando como empório comercial e centro de serviços. A cidade começava assim a concentrar grande poder político, econômico e social, desenvolvendo-se e firmando sua liderança no sul do Estado. Oliveira (2005, p. 21) observa que "no final do séc. XIX e início do séc. XX, as ferrovias determinavam o desenvolvimento sócio econômico das regiões brasileiras, interligando-as e abrangendo novos horizontes por onde passavam seus trilhos de ferro".

\subsection{Da Privatização ao Tombamento}

Durante a economia do café, grande parte das ferrovias eram controladas pelo capital estrangeiro, e a partir da decadência da economia cafeeira, o setor ferroviário deixou de receber investimentos para sua modernização, o que resultou no seu sucateamento precoce.

Este processo teve início a partir da década de 1930, quando a economia do café que guiava o desenvolvimento e a expansão das estradas de ferro entra em colapso com a crise de 1929. Este período apresentou profundas mudanças, chegou ao fim a República Velha, limitando o poder dos coronéis com a centralização do poder no país. Intensificou-se o processo de industrialização do país mais precisamente na região Sudeste, com participação efetiva do Estado com investimentos pesados no desenvolvimento do transporte rodoviário seguindo a diretriz econômica mundial com base nas indústrias automobilísticas. $\mathrm{O}$ desenvolvimento do transporte rodoviário atendia os interesses do capital internacional. Depois da crise de 1929, a indústria automobilística emergia como o novo boom da economia capitalista mundial. No Brasil, o ponto alto foi a implantação do parque da indústria automobilística estrangeira na década 1950 sob orientação do Plano de Metas do presidente Juscelino Kubitschek.

Após a crise de 1929, o setor ferroviário foi transferido para o controle estatal entre as décadas de 1930 e 1950, neste período já estava sucateado e necessitando de reformas, sendo 
importante ressaltar que na década de 1950 o transporte rodoviário ganhava corpo no país. Em 1957, a NOB foi uma das 18 empresas formadoras da Rede Ferroviária Federal S.A. - RFFSA, uma sociedade de economia mista criada com a finalidade de concentrar todo o patrimônio ferroviário pertencente à União.

O sistema ferroviário foi importante para o Brasil até as primeiras três décadas do século $\mathrm{XX}$, porém com as transformações econômicas, as ferrovias deixaram de ser prioridade, devido ao investimento massivo no transporte rodoviário, devido a adoção de um novo modelo de transporte que ganhava corpo no país. O setor automotivo e a exploração de petróleo eram centrais neste momento do desenvolvimento capitalista e estes interesses orientaram a política de transporte nacional, dado o caráter dependente da economia brasileira. Justificando assim a adoção de um novo modelo de transporte em detrimento da utilização das vias férreas existentes.

A partir da década de 50, no governo de Getulio Vargas e posteriormente Juscelino Kubitschek se deu o inicio da abertura do mercado para as montadoras multinacionais do setor automotivo gerando uma quantidade maior de investimentos na construção de rodovias.

Segundo Peixoto (1977), as ferrovias tornaram-se deficitárias por falta de investimentos, e o Estado, juntamente com as transformações econômicas, direcionavam os novos investimentos e fluxos de mercadorias para as rodovias, redirecionando massivamente os recursos para infraestrutura dos transportes para o setor rodoviário. Durante as últimas décadas foram poucos os investimentos do Governo Federal no sistema ferroviário buscando a modernização do sistema.

As únicas exceções foram a implantação da Estrada de Ferro Carajás na região Norte do Brasil para viabilizar a exportação de minério de ferro e aço para o mercado internacional, e os projetos da Ferrovia Norte-Sul e Ferronorte, até hoje não concluídos. O Governo Federal não promoveu grandes investimentos, a malha ferroviária se manteve abandonada e muitos trechos foram desativados (KATINSKY, 1994).

A partir da década de 1990, com a consolidação da política neoliberal no país, iniciou-se o processo de privatização das ferrovias, através desse modelo político o governo defendia o Estado mínimo como resultado de ajustes impostos pelo FMI - Fundo Monetário Internacional, que gerou a privatização não apenas das ferrovias, mas também, outros setores da infraestrutura nacional, como energia e telefonia. Entendendo que o real motivo das privatizações estava em desonerar o Estado destes investimentos em infraestrutura deixando que o privado o fizesse, 
dessa forma a lógica capitalista se impôs, e só "merecia" ficar em "pé" onde fosse possível lucrar, o que levou a desativação, por exemplo, de vários ramais ferroviários, como o ramal de Ponta Porã, braço da NOB em direção ao Paraguai.

O governo Collor de Melo deu início às reformas neoliberais no Estado e na economia no País: promoveu a abertura da economia, extinguindo a maior parte das barreiras não-tarifárias existentes até então e estabelecendo um cronograma de redução das tarifas de importação no País (entre 1990 e 1994, a tarifa média de importação no Brasil baixou de 48\% para 15,4\% e a máxima de 156\% para 44,6\%), desregulamentou os fluxos de capital internacional no País;260 promoveu uma reforma administrativa, demitindo funcionários públicos, fechando entidades públicas e dando início a um processo de privatização de estatais. (CANO, 2000).

Após o Impeachment de Collor de Melo, o seu vice, Itamar Franco, assumiu a Presidência da República e manteve o projeto neoliberal de Collor. Com a implantação do Plano Real (fundamental para a eleição de Fernando Henrique Cardoso para Presidente, em 1994), lançou as bases para a consolidação da hegemonia do projeto neoliberal no Brasil (CADONÁ, 2009).

O governo FHC, que durou dois mandatos (de 1995 a 1998 e de 1999 a 2002), foi marcado pela combinação da abertura comercial, da sobrevalorização cambial, das altas taxas de juros, do crescimento pífio do PIB no período, pelo processo de desnacionalização da economia brasileira, pelos aumentos do déficit da balança comercial, da dívida externa, da dívida líquida do setor público, do déficit público operacional de todo o setor público e do desemprego. Estes indícios apontam o efeito catastrófico sobre a dinâmica de desenvolvimento econômico e social do país.

Neste período o processo de privatizações de empresas estatais e de serviços de infraestrutura, a submissão da indústria do País "à concorrência predatória de importações e de investimentos estrangeiros", o abandono do sistema de fomento estatal ao desenvolvimento econômico, foram fatores determinantes para um processo de desnacionalização da economia brasileira, sendo ilustrativo que, entre 1994 e 1998, o número de aquisições de empresas brasileiras por empresas estrangeiras tenha crescido 146\% (CADONÁ, 2009).

O Brasil viveu um momento de enxugamento do Estado via privatizações, demissões voluntárias (PDV), uma transferência de deveres do Estado à iniciativa privada, onde o então governo prejudicou a nação, vendendo a baixos preços importantes setores da economia brasileira, exemplo da Vale do Rio Doce, REFFSA entre outros. 
A política neoliberal da década de 1990 traz consigo a concepção do Estado mínimo, requerida como nova forma de atração das Economias Satélites às nações hegemônicas, com algumas redefinições do papel do Estado, nos aspectos institucionais e regulatórios. De fato a teoria do Estado Mínimo, apenas repassou responsabilidades nacionais a iniciativa privada, trazendo uma série de crises ao país, que circundavam desde aspectos econômicos até aspectos sociais (demissões em massa, etc.), o que caracterizou o Brasil como um país de economia dependente.

Às associações econômicas regionais, com diminuição dos protecionismos e atração de investimentos internacionais, acrescentou-se a limitação dos gastos governamentais, com a prevalência da economia de mercado internacionalizado ${ }^{2}$.

Em um contexto geral o Estado mínimo envolveu ainda a redução dos gastos públicos (saúde, educação, previdência social, entre outros) significando, para os países desenvolvidos, o fim do Estado de bem-estar social, e para os países em desenvolvimento, o agravamento do quadro social. Esse fato trouxe ainda mais o distanciamento social entre as classes, pois ampliou as fraturas sociais de desigualdades entre extremos de pobreza para a maioria e riqueza para um reduzido número de pessoas.

Retomando o caso da RFFSA, a ferrovia foi incluída no Programa Nacional de Desestatização (PND) no ano de 1992 e foi dividida em seis malhas regionais: Malha Sudeste, Malha Centro-Leste, Malha-Sul, Malha-Oeste, Malha-Nordeste e a Ferrovia Tereza Cristina. Esta divisão em malhas regionais foi feita com o objetivo de comparar os resultados das operações ferroviárias, como a regularidade do funcionamento do sistema, segurança, produção e gestão, sendo possível desta forma identificar o fluxo econômico representado pelo transporte ferroviário.

Como "Malha Oeste", foi arrematada em 1996 pela Ferrovia Novoeste S.A.. Esta foi fundida em 1998 com a Ferronorte e a Ferroban através do consórcio Brasil Ferrovias S.A.. Em 2002 houve nova cisão da Novoeste, juntamente com outros trechos paulistas de bitola métrica, formando a chamada Novoeste Brasil. Por fim, em maio de 2006, houve fusão da Novoeste Brasil e da Brasil Ferrovias com a América Latina Logística, através de troca de ações entre os

\footnotetext{
${ }^{2}$ Retirado do endereço eletronico: http://hid0141.blogspot.com.br/2011/08/o-neoliberalismo-e-o-estadominimo.html, acesso em março de 2014.
} 
respectivos controladores. Após a privatização o transporte de passageiros praticamente foi extinto na malha oeste, e o transporte de cargas passou foi reduzido.

No final da década de 1990, o setor ferroviário continuou prestando serviços, apenas para um pequeno número de empresas clientes, limitando-se no transporte de cargas de baixo valor agregado e de pequena diversidade. No Brasil, das cargas transportadas por ferrovias, 90\% são produtos de origem mineral, combustíveis, cimento e grãos agrícolas. Somente o minério de ferro representa cerca de $70 \%$ do volume transportado. Os serviços de transporte de passageiros foram desativados, com exceção dos trens metropolitanos das grandes cidades, e não foi priorizado o transporte ferroviário de passageiros para o desenvolvimento da integração entre as cidades do interior do Brasil. (MARQUES, 1996).

Neste período o quadro de funcionários foi reduzido drasticamente, alguns conseguiram aposentar por já terem tempo de serviço, outros foram contratados pelas novas empresas que assumiram o controle da malha nos anos seguintes, porém a maioria foi demitida.

Os anos seguintes à privatização são marcados pelo sucateamento e abandono dos bens da ferrovia, desde equipamentos apodrecendo no pátio da ferrovia até a ação de vândalos que depredaram e saquearam parte do conjunto ferroviário. Abandono este caracterizado pela falta de investimento do setor privado agora detentor das malhas ferroviárias brasileiras, que não obtendo lucro deixaram a malha ferroviária em total abandono, sem planos de melhorias, minimizando a importância que a mesma sempre teve no país. Fato este que demonstra a ação do Estado mínimo, que ao entregar o patrimônio público ao setor privado, "doa" sua responsabilidade com o desenvolvimento do país a lógica do lucro, que quando não ocorre, caracteriza o abandono e o descaso.

É neste contexto de abandono da ferrovia que o tombamento aparece como tentativa de salvaguardar este patrimônio que no setor privado deteriorou.

Em 1996 ocorre o tombamento e inserção no livro de tombos do município pelo poder municipal, através da Lei - 3.249 no dia 13/05. Este tombamento traz nove artigos que de forma geral, tutelam o complexo ferroviário, colocando restrições sobre ações de modificações e descaracterização dos elementos que constituem este complexo. O tombamento foi realizado no mandato do Prefeito Juvêncio César da Fonseca.

Um ano pós o tombamento municipal, os bens da ferrovia também são tombados pelo poder Estadual pela Lei 1.735, de 26/03/1997, dispondo sobre o tombamento dos sítios históricos 
localizados, desde Três Lagoas até Corumbá, consistentes das Estações Ferroviárias da antiga NOB e seus respectivos entornos históricos. A tutela estadual possui cinco artigos, também restringem modificações e ações sobre os bens tombados, sem prévia consulta a Secretaria de Estado de Cultura e Esporte.

Já no ano de 2007 com a promulgação da Lei 11.843/2007 que dispõe obre o espólio da antiga RFFSA, extinta em janeiro do mesmo ano, o IPHAN passa a analisar os processos de integração e penetração nacional que a criação da Estrada de Ferro Noroeste do Brasil NOB/RFFSA foi capaz de proporcionar aos confins do território brasileiro.

No período de 2007/2008, foi realizado o levantamento das estações da ferrovia em Mato Grosso do Sul, totalizando 76 estações, o estado de Mato Grosso do Sul, antes parte da Província de Mato Grosso, possuía a estação ferroviária de Campo Grande como seu maior ponto de ligação com os grandes centros nacionais.

Após este período de levantamento e estudos sobre os bens da ferrovia em Mato Grosso do Sul, o complexo ferroviário de Campo Grande foi tombado pelo Governo Federal, sua importância para o patrimônio histórico brasileiro encontra-se no registro simbólico do papel exercido pela ferrovia na integração e modernização nacionais.

Sendo assim, após o ano de 2009 o patrimônio ferroviário de Campo Grande passa a estar sob tutela em três níveis diferentes, revelando a importância que possuem para historia regional e nacional.

Para finalizar este capítulo, é ponto interessante para reflexão o fato que na maioria dos países do mundo, mais especificamente na Europa o transporte ferroviário, não foi suprimido e sim adequado e modernizado, representando ainda grande importância tanto no transporte de cargas quanto de passageiros, enquanto no Brasil foi colocado como obsoleto frente ao transporte rodoviário. Fica a questão sobre o porquê do não aproveitamento da malha existente e da não modernização das ferrovias no Brasil, que ainda possuem suas operações através de concessões do governo, mesmo com a maior parte dos trechos em péssimas condições de operação. 


\section{Capítulo 2: O Patrimônio Ferroviário em Campo Grande-MS}

Este capítulo traz a contextualização do processo no qual as ferrovias se tornam patrimônio cultural, passando por um resgate dos estudos sobre o reconhecimento do patrimônio industrial principalmente na Europa e no Brasil. Em um segundo momento será apresentado o levantamento de campo sobre o patrimônio ferroviário de Campo Grande, sob a perspectiva de complexo ferroviário, entendendo que o mesmo não é apenas um conjunto de prédios, mas sim um conjunto que reflete as relações impostas pela dinâmica do trabalho na ferrovia.

Por último será apresentado a discussão sobre os níveis de tombamento que o complexo ferroviário esta inserido, buscando detalhar estes níveis de tutela, suas semelhanças e principalmente evidenciando a importância da ferrovia para a cidade a ponto de ser tombada pelos três níveis: municipal, estadual e federal.

\subsection{Como Surge o Patrimônio Ferroviário}

Para entendermos a questão da preservação do patrimônio ferroviário e necessário buscar seus antecedentes, mesmo parecendo que a principio estamos discutindo um patrimônio relacionado especificamente aos transportes, o patrimônio ferroviário remonta ao patrimônio industrial, pelo aparato tecnológico que representa, pela transformação que causou nas cidades onde teve relevância, seja por sua consolidação ao desenvolvê-las ou por o seu traçado em si ter feito - as surgirem, nascendo de seu leito e principalmente pela transformação que causou no modo de vida das pessoas, marcando o início de grandes mudanças sociais, políticas e econômicas.

A partir da década de 1960, com a ampliação conceitual de patrimônio é que os bens ligados a industrialização passam a ser compreendidos como tal. $\mathrm{O}$ patrimônio industrial surge, segundo Kühl (2006), no contexto da ampliação daquilo que é considerado bem cultural, sendo que o debate se iniciou na década de 50 na Inglaterra. A autora afirma que significativos esforços foram realizados para definir o que é patrimônio industrial, compreendendo a busca por estabelecer parâmetros cronológicos, elaborar registros e estudos com o objetivo de definir o que e por que preservar, dando início a uma série de discussões a respeito da definição de monumento industrial.

$\mathrm{Na}$ Grã-Bretanha consideravam como monumentos industriais qualquer estrutura ou edificação especialmente oriunda da Revolução Industrial, incluindo os processos industriais e 
técnicos, bem como os meios de comunicação (KUHL, 2008). Tal vinculação rendeu críticas por parte de muitos estudiosos, em razão da diversidade das épocas e fases de industrialização nos diferentes países. Sendo assim novos conceitos foram formulados, a partir da supressão da demarcação cronológica atrelada à Revolução Industrial.

$\mathrm{O}$ termo arqueologia industrial apareceu pela primeira vez na Inglaterra, na década de 50, a partir de uma publicação de Michael Rix, professor da Universidade de Birmingham, no Reino Unido, cujo teor do termo alerta para a importância da documentação e preservação dos bens oriundos da industrialização e seu impacto sobre a sociedade (KUHL, 2008).

A arqueologia industrial, que não deve ignorar nada do que ensina a história tradicional, tem por objeto principal a pesquisa e o estudo dos sítios onde se desenrolaram esses tipos de atividade, e os testemunhos artificiais, os artefatos, que aí permanecem. Mas trata-se do primeiro passo da então nova disciplina. A pesquisa e a observação permitem identificar o que não foi ainda destruído, determinar a sua historicidade, apreciar seu interesse, provocar sua salvaguarda (KÜHL, 2003).

Em 1959, o Conselho Britânico de Arqueologia (Council for British Archaeology) cria o Comitê de Pesquisa para a Arqueologia Industrial. Para o órgão, Monumento industrial é qualquer edificação ou outra estrutura permanente, em especial do período da Revolução Industrial, que, sozinha ou associada à maquinaria ou equipamento, ilustra ou é significativamente associada ao começo e evolução de processos industriais e técnicos, referindo-se tanto à produção quanto aos meios de comunicação. (SOUKEF, 2013).

Em 1962, com o desaparecimento da pioneira Estação Ferroviária de Euston e da Bolsa do Carvão (Coal Exchange), é que surge uma reocupação maior com a preservação dos bens industriais britânicos e a conscientização de que seus remanescentes são parte integrante de uma herança cultural mais ampla (SOUKEF, 2013).

Este fato despertou no país o interesse pela salvaguarda dos bens industriais, do mesmo modo que as edificações e sítios arqueológicos tradicionais. A partir de sua valorização, o patrimônio industrial, em suas diferentes fases e etapas de desenvolvimento, tornou-se objeto de estudo e reconhecimento como parte do legado cultural britânico, tanto por seus atributos históricos quanto estéticos (SOUKEF, 2013).

Em 1973 foi realizada a I Conferência Internacional para a Conservação do Patrimônio Industrial, em Ironbridge, na Grã-Bretanha. Porém a preocupação com a questão do patrimônio 
industrial ganhou mais visibilidade, na III Conferência Internacional para a Conservação do Patrimônio Industrial, dessa vez realizada na Suécia, em 1978, quando foi instituído o TICCIH The International Committe for the Conservation of the Industrial Heritage, idealizado com o objetivo de promover discussões e cooperação no âmbito internacional no campo da preservação do patrimônio industrial (CAPAGNOL, 2009).

A partir da década de 1960 ocorre uma grande transformação na prática e nos conceitos patrimonial, que trouxe um refinamento das discussões no âmbito das ciências humanas possibilitando uma ampliação de bens de domínio patrimonial (CHOAY, 2006).

Ao longo da década de 1970, foram realizados vários estudos e inventários em vários países da Europa, reunindo esforços para consolidar a proteção sobre os bens industriais aumentando consideravelmente as manifestações em favor de sua proteção, principalmente na França, onde se formou uma comissão encarregada do patrimônio do século XX. Essa comissão procurou elaborar critérios e uma tipologia que não deixasse escapar qualquer testemunho historicamente significativo (CHOAY, 2006).

Surge então uma diferenciação entre patrimônio histórico e monumento histórico, pois este representa senão parte de uma herança que não para de crescer com a inclusão de novos tipos de bens, o alargamento do quadro cronológico e das áreas geográficas no interior dos quais esses bens se inscrevem (saindo do limite do século XIX e do espaço geográfico europeu).

Segundo Scifoni (2004) de um lado, o reconhecimento de obras de um passado recente, possibilitou o que Choay chamou de ampliação cronológica do patrimônio, incluindo-se, assim, os bens representativos da modernidade. De outro, o alargamento de visões possibilitou o reconhecimento de novas categorias de bens considerados como de valor cultural: habitações operárias, instalações industriais, o que implicou numa ampliação tipológica deste patrimônio. Faz parte desta ampliação tipológica o reconhecimento, em definitivo, da importância do patrimônio natural, por exemplo.

A partir deste momento começa a surgir uma terminologia conceitual, porém a maioria dos estudos ainda utilizava tanto o termo arqueologia industrial como patrimônio industrial.

Este ponto é importante, pois a partir desta ampliação conceitual incluem-se não apenas as arquiteturas das fábricas, mas todo o complexo, sendo aqui um ponto importante, pois os complexos ferroviários começam a ganhar importância. 
No Brasil os primeiros indícios industriais tombados na década de 1950 remetem a ferrovia, sendo constituído pelo trecho ferroviário Magé- Fragoso, no Rio de Janeiro (em 1954); pelos remanescentes da Real Fábrica de Ferro São João de Ipanema, em Iperó, São Paulo; e a Estação Central, no Rio de Janeiro (ambos na década de 60). O tombamento, neste período, constituía-se como único instrumento voltado para a preservação do patrimônio ferroviário, no âmbito nacional (LINS, 2012).

Na década de 1970, as discussões sobre a preservação patrimonial deslocam-se do objeto, ou seja, do monumento isolado para a interação com o conjunto integrando o patrimônio ao planejamento urbano e territorial. Ampliou-se também o recorte cronológico, com pesquisas referentes ao Império e República possibilitando a incorporação de novos elementos à memória histórica. Tornou-se necessário então, atualizar a administração dos bens tombados e a composição do patrimônio (RODRIGUES, 2012).

Com o objetivo de atender a essa demanda criou-se o Centro Nacional de Referência Cultural (CNRC) em 1975 cujo mentor foi Aloísio Magalhães através de um convênio firmado entre o Governo do Distrito Federal (pela Secretaria da Educação e Cultura) e o Ministério de Indústria e Comércio (pela Secretaria de Tecnologia Industrial) (FONSECA, 1997, p. 163). É interessante observar que alguns objetivos do CNRC tangenciaram em alguns aspectos a questão estudada aqui, da abordagem ao patrimônio industrial, na medida em que enfocava preferencialmente: “o trato da matéria prima, as formas de tecnologia pré-industrial, as formas do fazer popular, a invenção de objetos utilitários" (MAGALHÃES, 1985 apud FONSECA, 1997, p. 172) contribuindo para ampliar a noção de cultura popular abrangendo as manifestações populares tradicionais e suas interfaces com o mundo industrial urbano (RODRIGUES, 2012).

Rodrigues (2012) escreve que em 1979 ocorreu a fusão entre o CNRC e o IPHAN, o que contribuiu para uma ampliação conceitual do bem cultural. Na prática, as propostas de tombamento de "novos programas" ou do denominado "patrimônio cultural não consagrado" reforçou a necessidade de organizar novas referências conceituais. Com isso, a ampliação da perspectiva histórica possibilitou a atribuição de valor estético a bens como obras da tecnologia industrial tais como pontes, mercados, fábricas, caixas d’água, faróis, estações ferroviárias, entre outros.

Nesta época ocorre uma abertura para o que deve ser tombado, atendendo uma demanda que na referencia apenas ao apelo estético ate então vigente nas políticas de tombamento. 
Ao longo da década de 1980, uma série de pedidos é realizada ao conselho com base nos marcos da história, da ciência e da tecnologia ou exemplares da arquitetura do ferro (pontes, mercados, caixas d’água, açude, etc.), ou ainda exemplares da arquitetura civil (curtumes, fábricas e conjuntos habitacionais populares); e até "fazeres", como o objeto da proposta de tombamento da Fábrica de Vinho de Caju Tito Silva na Paraíba (FONSECA, 1997, p. 239-240 apud RODRIGUES, 2012).

Sobre os bens industriais oriundos da ferrovia, é na década de 90 que seus os monumentos aparecem mais evidentes na lista do Patrimônio Mundial. Neste período são desenvolvidos pelo Comitê do Patrimônio Mundial, planos estratégicos, sendo que o primeiro estudo realizado em 1992 teve como um dos objetivos analisar a Lista do Patrimônio e os critérios adotados. Verificou-se, à época, um desequilíbrio regional e de temáticas dos bens inscritos na Lista, ressaltando-se o pouco número de bens vinculados aos setores da arquitetura moderna, sítios industriais, paisagens rurais e canais (LINS, 2012).

Apesar do destaque recebido pelos bens industriais nestes estudos, apenas três bens ferroviários apresentam-se inscritos na Lista do Patrimônio Mundial: a Ferrovia Semmering, na Áustria, representando a primeira ferrovia a ser reconhecida como patrimônio da humanidade, em 1998; a Ferrovia Montanhosa na Índia, inscrita em 1999, e a Ferrovia Rhaetian, na Suíça, inscrita em 2008 (LINS, 2012).

No plano nacional, a privatização do sistema ferroviário a partir de 1995 determinou a desativação de milhares de conjuntos ferroviários em todo o território brasileiro, despertando o interesse de comunidades, órgãos culturais e universidades, para o problema do que fazer especificamente com esses remanescentes. Ações empreendidas a partir de então, embora ainda com resultados incipientes, obtiveram algumas conquistas como o tombamento de alguns bens, a reativação de linhas turísticas ou a criação de associações cujo objetivo é buscar meios para preservar o patrimônio oriundo das antigas ferrovias (SOUKEF, 2013).

Esta fase é marcada por tombamentos realizados pelos governos municipais, como o caso da NOB/RFFSA em Campo Grande.

De fato o discurso sobre o esta categoria ganha força quando em 2003 em uma reunião realizada na cidade de Nizhny Tagil, onde foi escrita a carta do patrimônio industrial. Este documento referência o patrimônio Industrial, conforme foi concebido em assembleia do TICCIH. 
A carta de Nizhny Tagil define o patrimônio industrial como:

\begin{abstract}
"os vestígios da cultura industrial que possuem valor histórico, tecnológico, social, arquitetônico ou científico. Estes vestígios englobam edifícios e maquinaria, oficinas, fábricas, minas e locais de processamento e de refinação, entrepostos e armazéns, centros de produção, transmissão e utilização de energia, meios de transporte e todas as suas estruturas e infraestruturas, assim como os locais onde se desenvolveram atividades sociais relacionadas com a indústria, tais como habitações, locais de culto ou de educação" (CARTA DE NIZHNY TAGIL, 2003).
\end{abstract}

Na carta à arqueologia industrial recebe a seguinte definição:

\begin{abstract}
"arqueologia industrial é um método interdisciplinar que estuda todos os vestígios, materiais e imateriais, os documentos, os artefactos, a estratigrafia e as estruturas, as implantações humanas e as paisagens naturais e urbanas, criadas para ou por processos industriais. A arqueologia industrial utiliza os métodos de investigação mais adequados para aumentar a compreensão do passado e do presente industrial". (CARTA DE NIZHNY TAGIL, 2003).
\end{abstract}

Outro importante momento ocorreu em 2003 quando se deu a fundação do Comitê Brasileiro de Preservação do Patrimônio Industrial composto por profissionais de diversas áreas e membros da comunidade acadêmica alinhando o Brasil, de forma oficial, junto ao TICCIH, o comitê surge como importante elemento nas discussões sobre a salvaguarda dos bens de origem industrial no país (SOUKEF, 2013).

Sobre a tutela especifica dos bens ferroviários no Brasil um importante marco é a Lei $\mathrm{n}^{\circ}$ 11.483/2007 quando Iphan passou a ter atribuições especificas para preservação da memória ferroviária. A Lei dispõe sobre a revitalização do setor ferroviário e estabelece em seu artigo $9^{\circ}$ :

Caberá ao Instituto do Patrimônio Histórico e Artístico Nacional - Iphan receber e administrar os bens móveis e imóveis de valor artístico, histórico e cultural, oriundos da extinta RFFSA, bem como zelar pela sua guarda e manutenção.

Esta lei foi criada com intuito de ampliar e especificar a proteção dos bens da extinta REFFSA, porém o tema ainda era recente e seu conteúdo trazia diversos assuntos ainda inéditos no âmbito jurídico, como por exemplo, memória ferroviária.

Dessa forma o Iphan publicou a Portaria $\mathrm{n}^{\circ}$ 407/2010 instituindo a Lista do Patrimônio Cultural Ferroviário como um novo instrumento de preservação, onde serão inscritos todos os 
bens declarados como detentores de valor artístico, histórico e cultural. A portaria instituiu, ainda, a Comissão de Avaliação do Patrimônio Cultural Ferroviário, responsável pela atribuição do valor, avaliando o patrimônio ferroviário a partir dos diferentes enfoques de atuação do Departamento de Patrimônio Material e Fiscalização do Iphan, que contemplam os bens móveis e imóveis, paisagem e cidade, passando a considerar a conservação desses bens em seus respectivos tecidos sociais e urbanos.

Essa portaria estabeleceu os critérios e a metodologia processual para valoração dos bens oriundos da extinta RFFSA. Ao criar a Lista do Patrimônio Cultural Ferroviário, garantiu que os bens inscritos passassem a ser protegidos visando a evitar sua degradação, apoiando sua conservação, divulgando sua existência e fornecendo suporte a ações administrativas e legais de competência do poder público.

Longe de ser definido apenas pelos aparatos materiais utilizados na indústria, o legado do patrimônio industrial referencia também os meios, os fazeres, e principalmente as relações construídas a partir das relações de trabalho, sendo muito mais complexo que a simples preservação material de seus bens físicos, influenciou nas relações do cotidiano e na construção da paisagem, seja pela presença marcante de seus edifícios ou pela caracterização espacial de determinada área.

\subsection{O Patrimônio da NOB como Complexo Ferroviário}

Já destacamos que o início do processo de implantação ferroviária no território brasileiro traz consigo um novo ordenamento espacial, mesmo nos lugares que se configuravam como ponto de passagem dos trens, a ferrovia realizou a integração das cidades menores a grandes centros urbanos, encurtando distancias e desenvolvendo relações comerciais, mais complexas do que as presentes naquelas cidades ate então, contribuindo com o processo de modernização do campo e o inicio da urbanização para muitas cidades as quais foram cortadas pela ferrovia.

Sabe-se que, no Brasil, sob a influência inglesa no modelo de transporte de carga e de passageiros, implantou-se um extenso, complexo, diverso e único modus operandi ligado ao contexto das ferrovias. Seguindo planejamento próprio e característico, sendo formados por estações, prédios para armazenagem da carga, oficinas, residências entre outros, contemplando assim o que se conhece hoje como complexos ferroviários. 
Tais complexos eram construídos em lugares estratégicos de acordo com razões de ordem econômica (de produção), técnica, social ou política. Frequentemente estes fatores eram determinantes, simultaneamente, o que permite entender tais áreas, realmente, como "complexos", que eram interligados pela linha férrea que formavam o sistema ferroviário brasileiro. Poderiam ser aproveitados locais que tinham sido utilizados historicamente como caminhos, portas de entrada e saída de cidades, espaços de escoamento de produção por se situarem em espaços privilegiados, localização geográfica que possibilitava a construção e o assentamento de trabalhadores. Isso mostra a imbricada rede de aspectos que caracterizam os pátios e os complexos ferroviários no Brasil (FREIRE et al., 2012).

Um complexo ferroviário é formado por compartimentos e elementos, que traduzem uma funcionalidade produtiva, uma rede de relações de trabalho e um campo de relações e controle social. Neste espaço atribui-se destaque, em termos sociológicos, às vilas ferroviárias: locais de moradia de trabalhadores e diretores das ferrovias, onde as relações de vizinhança e a hierarquia social se intercalam às relações de trabalho e de produção. São inspiradas nos modelos de vilas destinadas a abrigar trabalhadores das indústrias (FREIRE et al., 2012).

Por este motivo, falar em patrimônio ferroviário consiste, de certa maneira, em falar de patrimônio industrial, pois o mesmo foi essencial à revolução industrial. Essas vilas são marcadas pela distribuição espacial singular das residências e suas características arquitetônicas, mostrando, de modo evidente, diferenças sociais entre os trabalhadores braçais e os dirigentes das ferrovias, como se pode ver em Paranapiacaba (Santo André - SP) - um exemplo bem preservado de unidades de moradia - e em Vila Belga (Santa Maria - RS), como discute Finger (2009).

Diante disso, pode-se afirmar que, de fato, as vilas ferroviárias são espaços em que se dá algo mais do que simplesmente a estratégia de funcionamento logístico. Nas vilas funcionava um mecanismo de controle social, no sentido em que elas auxiliam a situar no espaço dos complexos ferroviários os trabalhadores e os chefes, os mais pobres e os mais ricos. Esse mecanismo se expressa desde a construção mesma - arquitetura - das casas dos que trabalham no complexo até a disposição delas no espaço - urbanismo (FINGER, 2009).

Pode-se perceber que as casas dos diretores e de funcionários de cargo mais elevado são arquitetonicamente mais elaboradas e mais amplas, além de estarem situadas em local no terreno 
de maior destaque - das casas dos trabalhadores de cargo mais baixo, próximas umas às outras e distantes daquelas, o que lhes confere a relação e a organização de "vila".

A concepção territorial de um pátio ferroviário está diretamente relacionada a construção de grandes vazios e implantação dos edifícios de forma esparsa devido a necessidade de existir espaços para realizar as operações de descarga, carga e de formação dos trens de acordo com o destino de cada vagão que constitui a composição ferroviária. Os trens (entenda-se aqui a composição ferroviária formada por locomotivas, vagões e carro de passageiro) eram formados de acordo: com o número de vagões e carros de passageiros a serem tracionados, o que condicionava o número de locomotivas necessárias; o destino das cargas; e ainda, o tipo de linha onde a composição iria trafegar isto é a curvatura, rampa, bitola e etc (FREIRE et al., 2012).

\section{Levantamento e Espacialização dos bens}

Entendendo a importância que o complexo ferroviário teve ao longo dos anos para o desenvolvimento de Campo Grande e a influência que exerceu na vida dos moradores da cidade, buscaremos nesta próxima etapa da pesquisa detalhar o universo ao qual os bens da ferrovia NOB fazem parte, sua importância no contexto atual, não só do município que o abriga, mas também nas políticas públicas que tutelam esta tipologia de patrimônio. O levantamento a seguir tem como base os bens tombados nas três esferas de poder.

Nas pesquisas de campo realizadas para o desenvolvimento deste trabalho foi possível, levantar os bens da ferrovia para confronto com a listagem sugerida pelos tombamentos Municipal e Estadual. O principal objetivo deste levantamento é apontar o estado atual dos bens, o andamento do processo de revitalização e analisar sua requalificação enquanto ao uso, ou seja, como os bens estão inseridos nesta nova configuração urbana proposta

Na Foto 1, temos o complexo ferroviário na década de 30, é possível visualizar além do prédio da estação e os casarões da ferrovia, a formação central de Campo Grande, que teve esta região ocupada de forma mais efetiva após a inauguração da estação ferroviária em 1914. Na foto já temos o segundo edifício da estação, construído em 1935 visto que o prédio atual já não atendia a demanda de passageiros e volumes de cargas. 


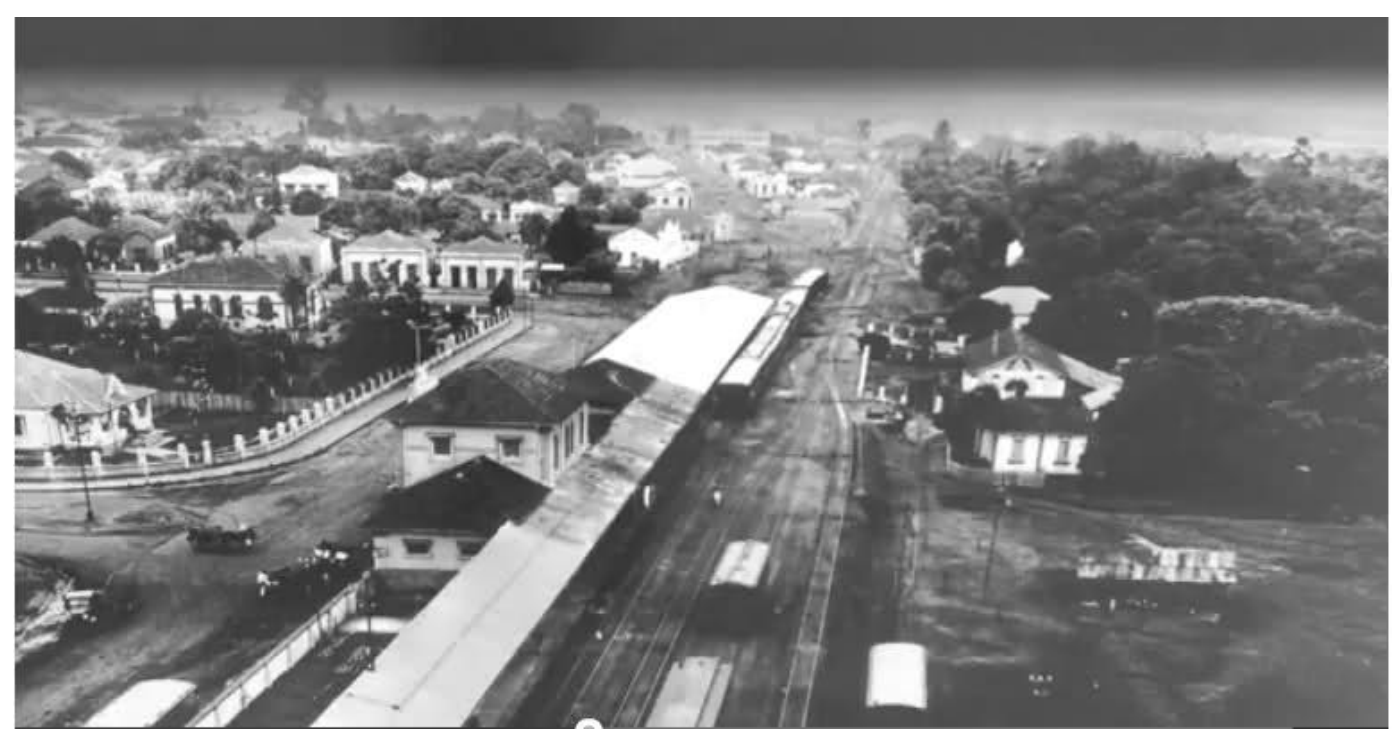

Foto 1. Complexo ferroviário de Campo Grande década de 30. Fonte: ARCA.

O complexo ferroviário (Figura 7) é composto pela Estação Ferroviária, escritórios, oficinas, armazém, rotunda de manutenção, casas para operários, casas para funcionários intermediários, casas para funcionários graduados, caixa d'água e escola, o conjunto de 160 edificações 110 em alvenaria e 50 em madeira, ocupa 22,3 hectares.

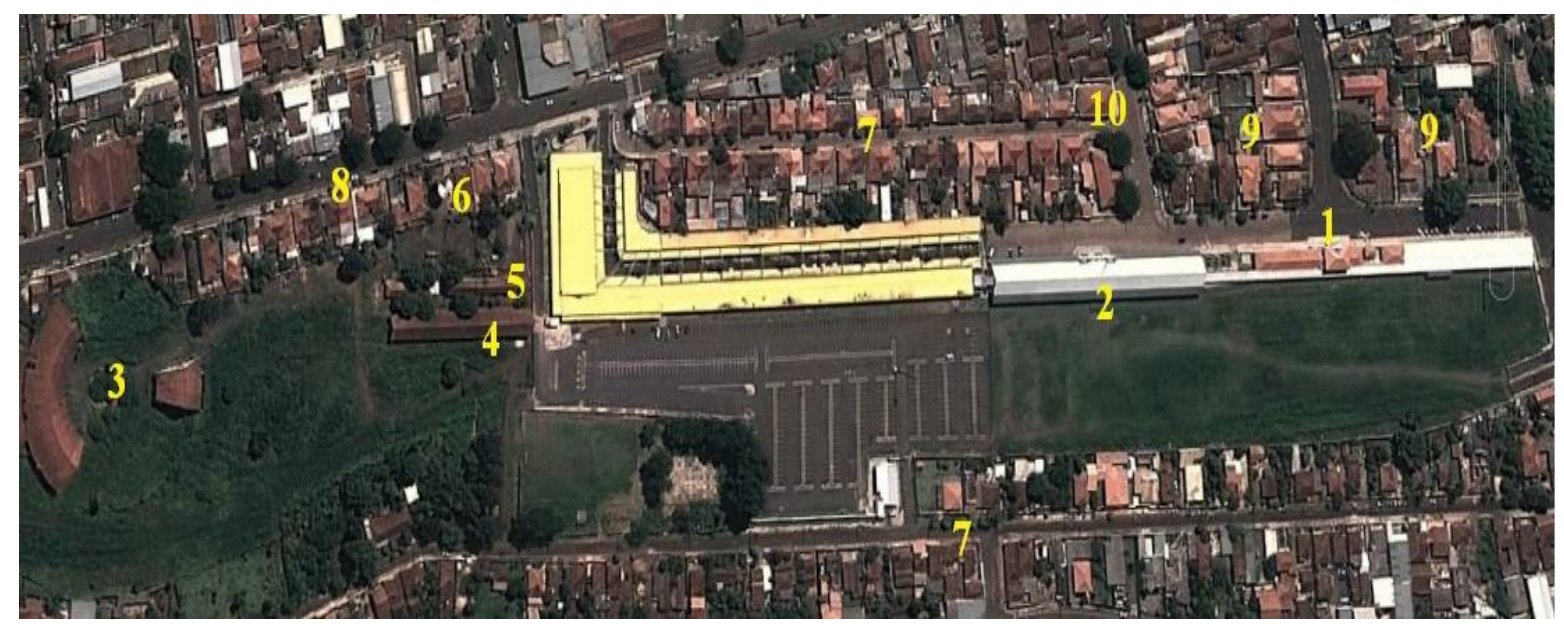

Figura 7. Complexo ferroviário em Campo Grande. Os números representam: 1- Estação, 2 - Armazém, 3 Rotunda, 4 - Oficina, 5 - Pernoite, 6 - Caixa D’água, 7 - Vila Ferroviária, 8 - Residências de funcionários intermediárias, 9 - Residências de funcionários graduados, 10 - Escola Álvaro Martins Neto.

A construção do complexo ferroviário ocorreu após o crescimento econômico com a enorme movimentação de cargas e de passageiros, verificados a partir de 1919, com a abertura dos mercados após a Primeira Guerra mundial. Os comerciantes sentiam-se impulsionados em 
importar produtos e exportar, principalmente a charque e com isso, Campo Grande passou a ser analisada pelos dirigentes da NOB, como uma localidade onde deveria haver mais investimentos por parte da companhia, localizado na porção centro-norte da cidade. Fazem parte da área tombada os imóveis residenciais e não residenciais.

A Figura 8 apresenta as ruas que delimitam o complexo ferroviário; a disposição dos imóveis se encontra da seguinte maneira:

- Rua Dr. Ferreira: 59 imóveis, sendo 58 residenciais (30 do lado direito, sentido norte e 28 no lado oposto) e a Escola Estadual de Primeiro Grau Álvaro Martins;

- Rua 14 de Julho: 27 imóveis sendo 26 residenciais e o Antigo Clube da Noroeste, atualmente usado pela Associação dos Aposentados da RFFSA;

- Rua dos Ferroviários: 46 imóveis residenciais, quase todos de madeira, exceto dois;

- Rua General Mello: quatro imóveis sendo três residenciais e o utilizado pelo escritório da RFFSA em Campo Grande;

- Rua Dr. Temístocles: cinco imóveis, sendo quatro residenciais e a sede do Sindicato dos Trabalhadores Ferroviários;

- Rua Calógeras: 10 imóveis sendo oito residenciais (as maiores casas da antiga NOB) além da Estação Ferroviária e do Armazém;

- Av. Mato Grosso fecha o complexo, o casarão dos chefes da ferrovia faz esquina com esta avenida.

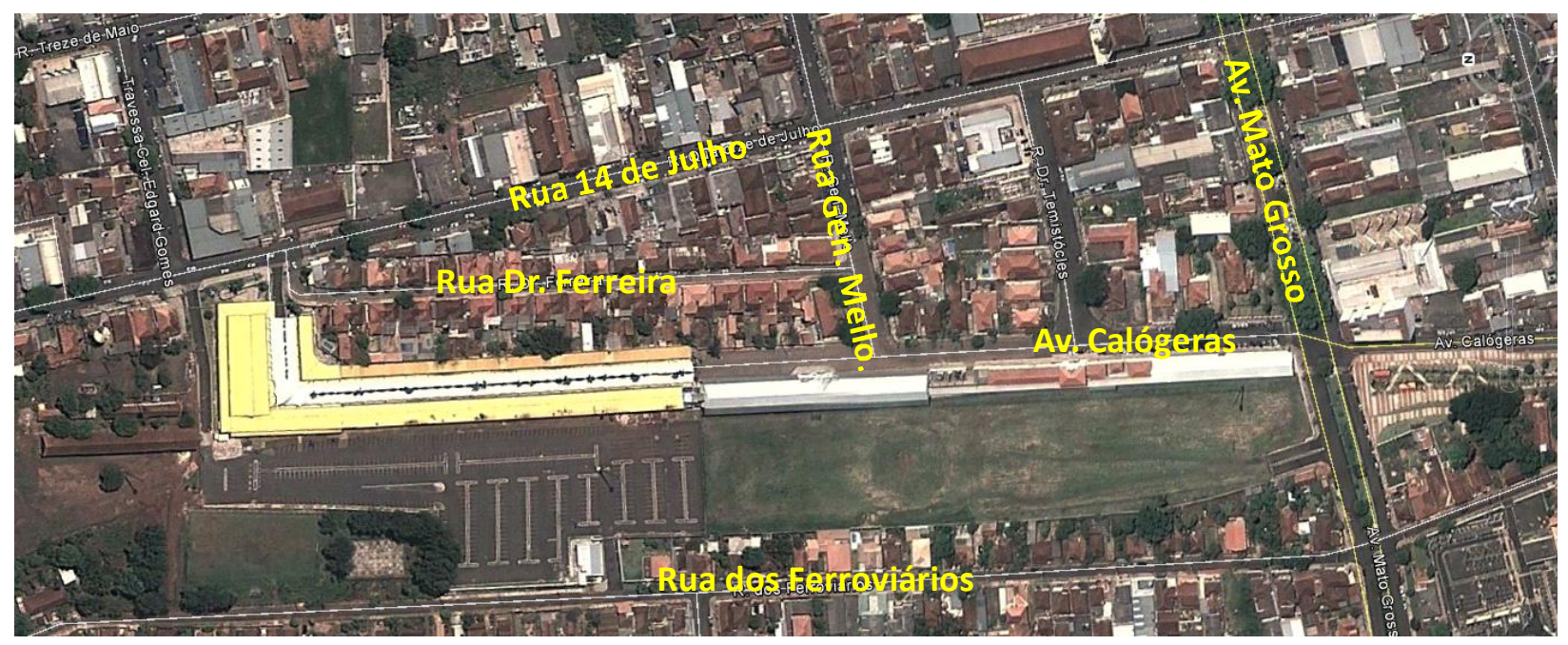

Figura 8. Ruas que compreendem o complexo ferroviário em Campo Grande. 


\section{- Tipologias Presentes no Complexo Ferroviário}

Dividem-se em três grupos: os edifícios ferroviários, as de uso residencial e os equipamentos urbanos. Compreendem a tipologia de edifícios ferroviários: a estação ferroviária, seu armazém, escritórios, os galpões e oficinas ao longo da esplanada e a rotunda de manobras.

A tipologia de uso residencial compreende: as casas dos operários da ferrovia, dos funcionários de nível intermediário e dos funcionários graduados. Na tipologia de equipamentos urbanos se inserem, o clube Noroeste e a Escola Álvaro Martins Neto.

\section{a) Edifícios ferroviários}

\section{- Estação ferroviária}

A primeira estação central de Campo Grande/MS foi inaugurada em 1914, de estrutura em madeira atendia as necessidades simples, era constituída por bilheteria, sanitários, apoio ferroviário e área de embarque (Foto 2). Em 1924 a edificação foi ampliada com embasamento de pedras e parede de tijolos (Foto 3).

$\mathrm{Na}$ década de 30, a partir das novas necessidades que surgiram com o crescimento da cidade e o aumento da circulação de cargas e passageiros, a NOB decidiu implantar uma diretoria regional atendendo a todo o sul do antigo Mato Grosso. Com isso uma nova estação foi construída, teve como executor o engenheiro Aurélio Ibiapina. O novo prédio foi erguido (Foto 4) em alvenaria de tijolos maciços nos padrões das pequenas estações europeias, e a obra era composta por: saguão, armazenamento e despacho de bagagens, bilheteria, sanitário, restaurante, cozinha e sala da administração. Os ambientes estavam distribuídos em três blocos: corpo principal (com dois pavimentos), a bateria de sanitários e o setor do restaurante tendo a plataforma como conexão entre esses três volumes.

Além dos ambientes descritos da estação, ela também possuía na extremidade da ala direita a sala da eletrotécnica, hall e PABX. Havia também a sala do supervisor de tráfego, e agência bancária, local para guarda e despacho de bagagens e sala da composição. Na ala esquerda localizava-se a bilheteria, sala da escala, posto médico e o bar/lanchonete.

A estação sofreu modificações ao longo dos anos, recebendo elementos mais modernos como janelas de metal, substituindo as antigas de madeira, segundo contam os ferroviários mais antigos, o relógio redondo original do bloco central foi substituído na década de 1970 por um 
quadrado, e neste mesmo momento um novo bloco de sanitários foi construído na ala esquerda da estação, assim como outras obras ocorreram até a desativação da estação na década de 1990.

A estação ferroviária teve um papel preponderante no desenvolvimento do estado do Mato Grosso do Sul e sua edificação possui grande representatividade na história do Complexo Ferroviário de Campo Grande. Nas fotos apresentadas tem-se a estação três épocas diferentes, de seu pleno uso ao período que foi desativada (Fotos 5 e 6), servindo por um tempo como sede da guarda municipal de Campo Grande até o período de restauro e entrega do bem restaurado.

A estação pode ser considerada o símbolo máximo da história da ferrovia em Campo Grande, assim como em outras cidades brasileiras, pois virou ponto de referencia no município e impulsionou o desenvolvimento e ocupação de seu entorno ao longo dos anos, sendo responsável pela urbanização e crescente adensamento, influenciando inclusive a arquitetura das casas e prédios que se ergueram na região.
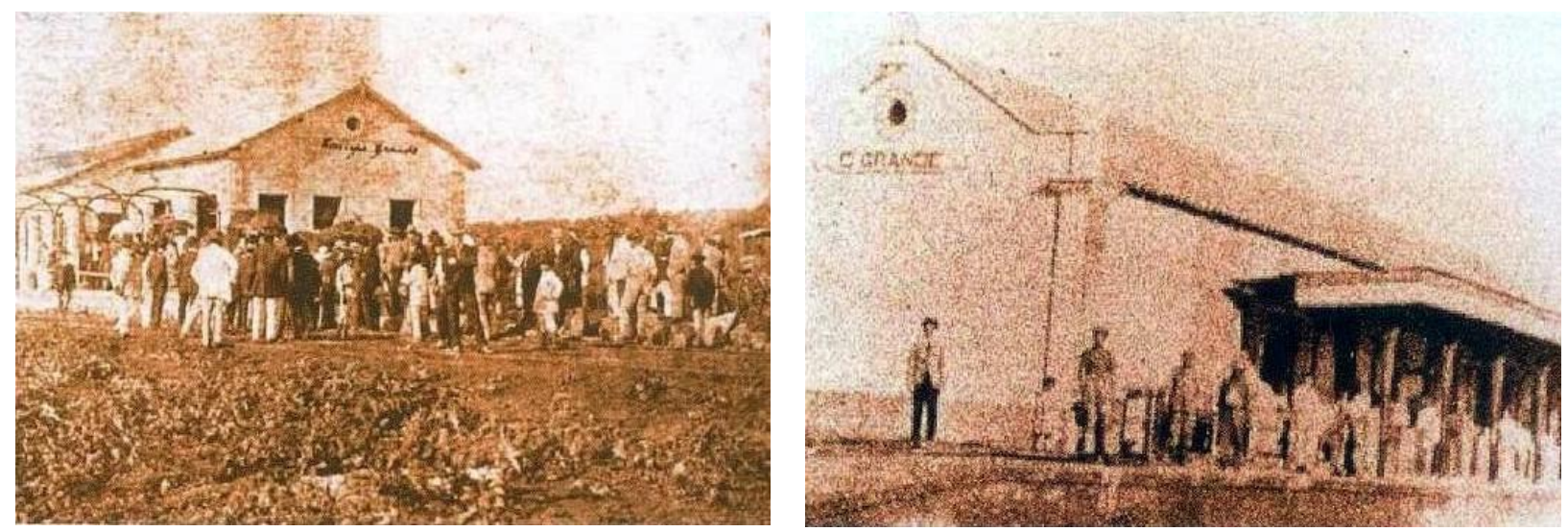

Foto 2 e 3. Estação em 1916 e 1924. Fonte: Arruda (2009).

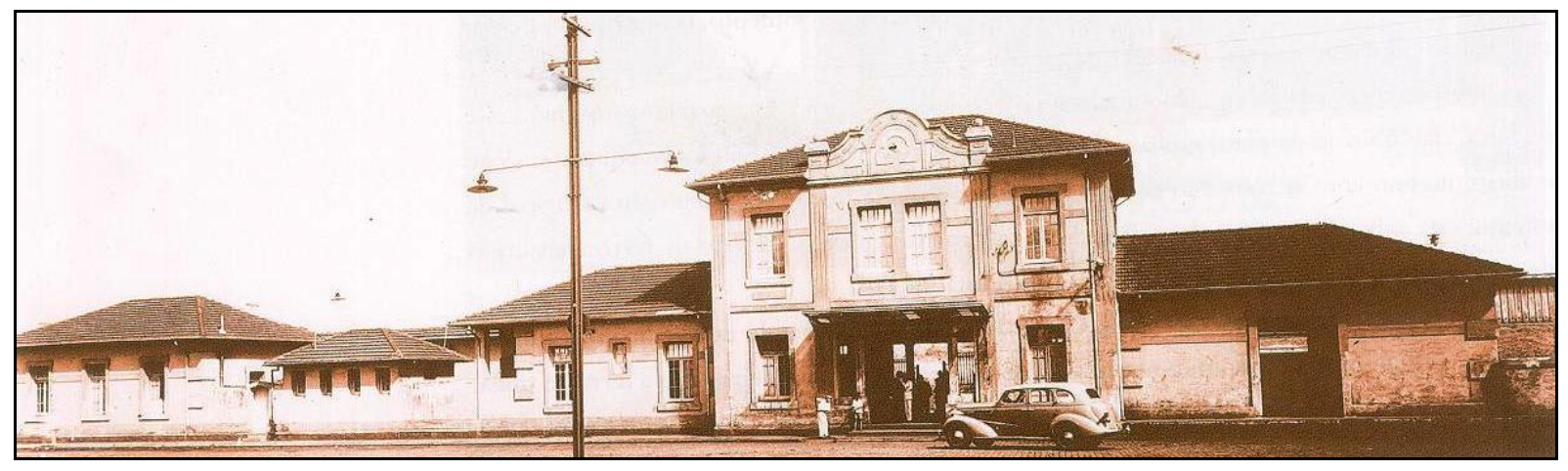

Foto 4. Estação em 1936. Fonte: Arruda (2009). 

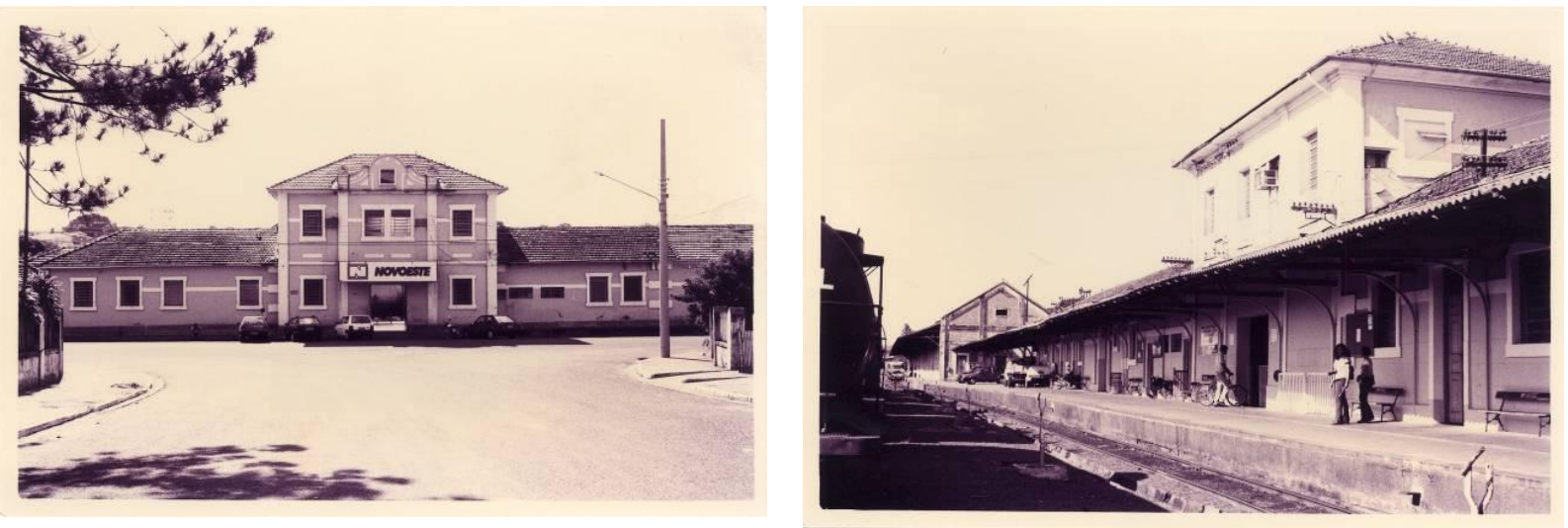

Foto 5 e 6. Estação década de 1990. Fonte: IPHAN.

\section{- Armazém}

O armazém foi construído em 1938 no prolongamento da estação no sentido da esplanada ferroviária devido à necessidade de um maior espaço de armazenamento de cargas (Fotos 7 e 8).

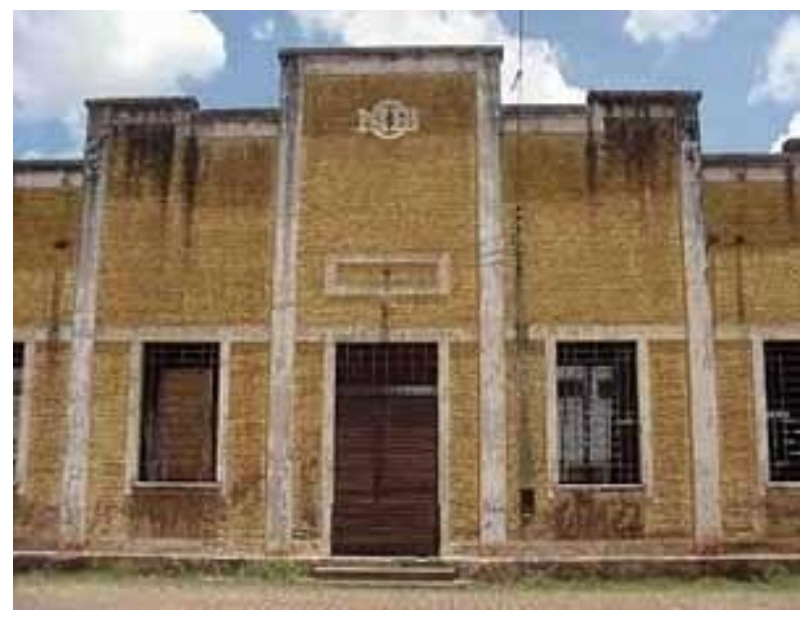

Foto 7. Armazém década de 1990. Fonte: ARCA.

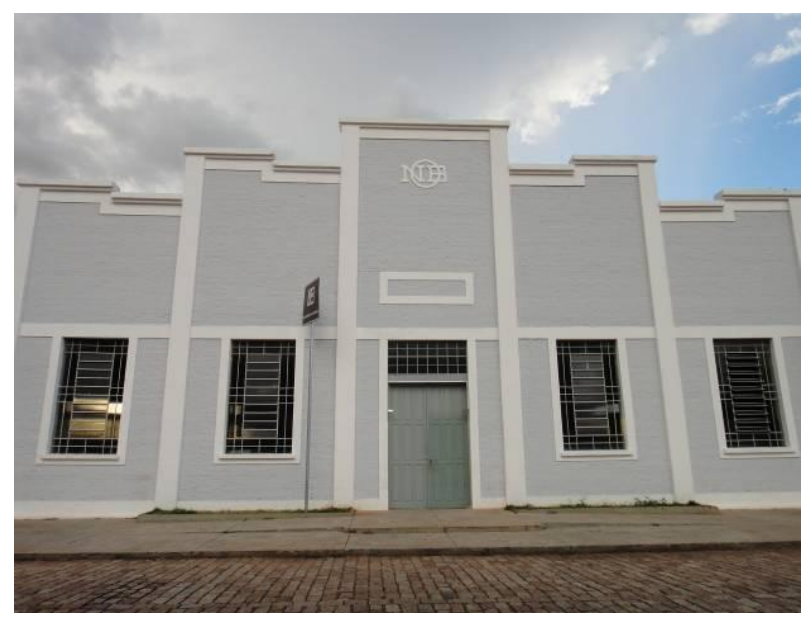

Foto 8. Armazém em 2012. Fonte: Próprio autor.

Hoje o armazém é utilizado como espaço de eventos, no seu restauro procurou-se manter todas as características originais da época de sua construção com exceção das janelas que originalmente eram de madeira e foram substituídas por janelas de metal ao longo dos anos.

\section{- Escritório dos engenheiros}

Localizado na Rua General Mello esquina com Av. Calógeras, foi construído para ser o local de trabalho dos engenheiros da ferrovia, também foi escritório da RFFSA após a privatização. Neste período trabalharam apenas três funcionários, um advogado e dois auxiliares 
de processo. Neste momento o escritório sediava os tramites dos processos que envolviam os funcionários demitidos, além do inventariado dos bens remanescentes da ferrovia (Fotos 9 e 10).

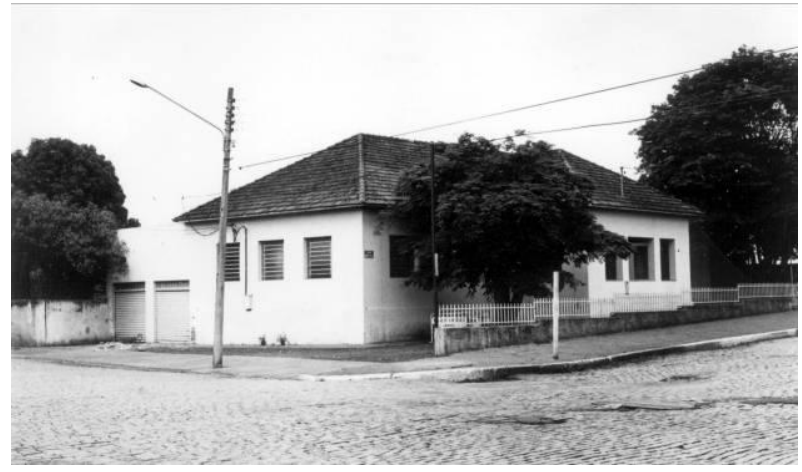

Foto 9. Escritório na década de 1990. Fonte: IPHAN.

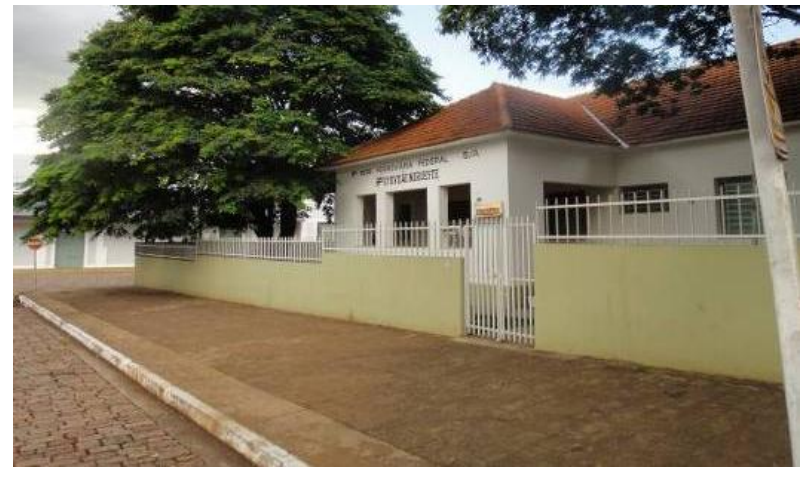

Foto 10. Sede do Iphan 2012. Fonte: Próprio autor.

\section{- Galpões e Esplanada}

Ao longo da esplanada existem alguns edifícios, onde funcionavam: um depósito e almoxarifado das oficinas (Foto 11) um Galpão de Manutenção de Veículos (Foto 12), o setor de pernoite de ferroviários (Foto 13), oficina elétrica (Foto 14). Esses prédios são construídos em alvenaria de tijolos, com forro de madeira e cobertura com telhas de barro francesas.

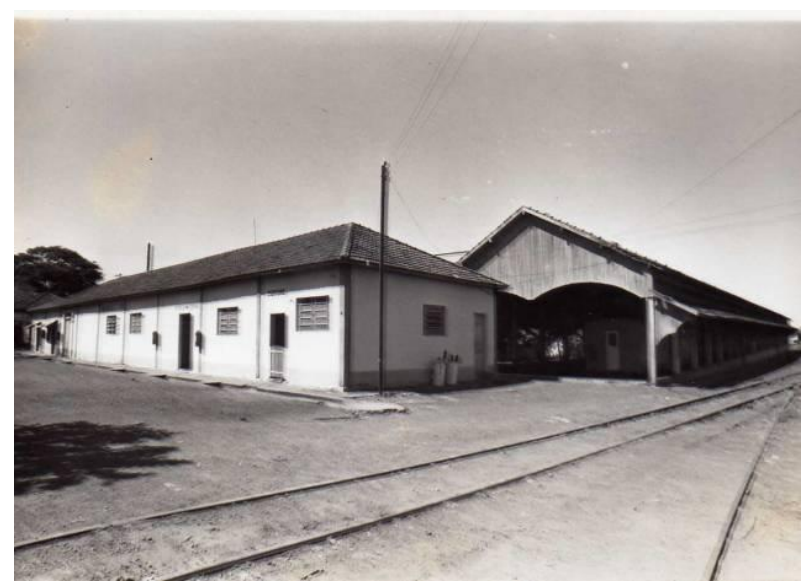

Foto 11. Depósito/almoxarifado Fonte: Arca

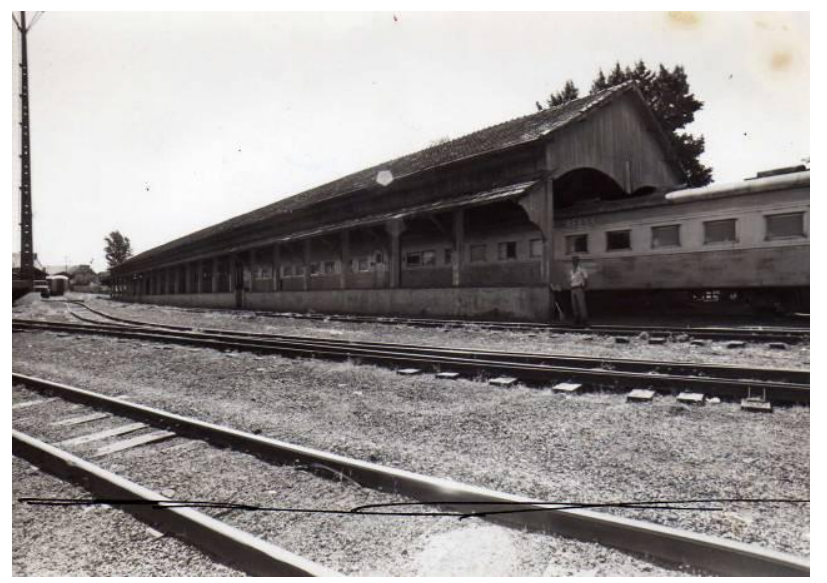

12. Galpão de manutenção e limpeza dos vagões, década de 1970. Fonte: Arca. 


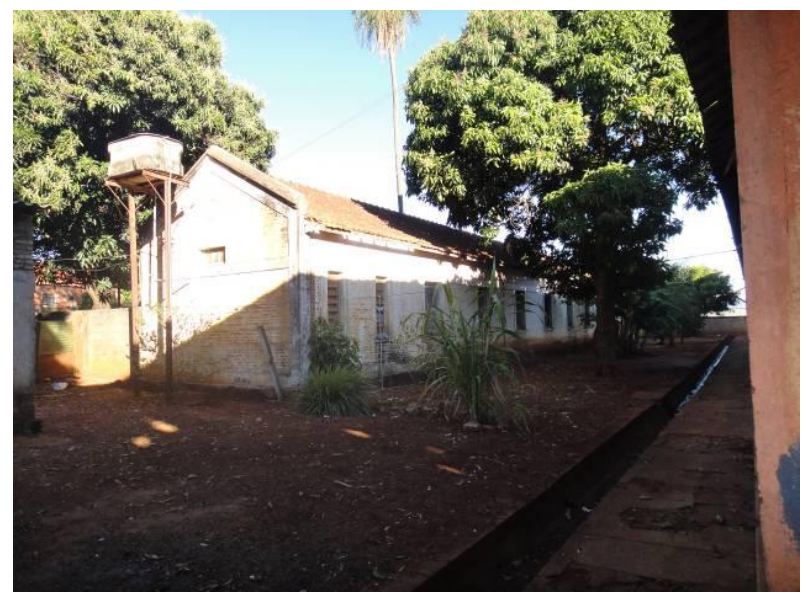

Fotos 13 Pernoite Fonte: Próprio autor.

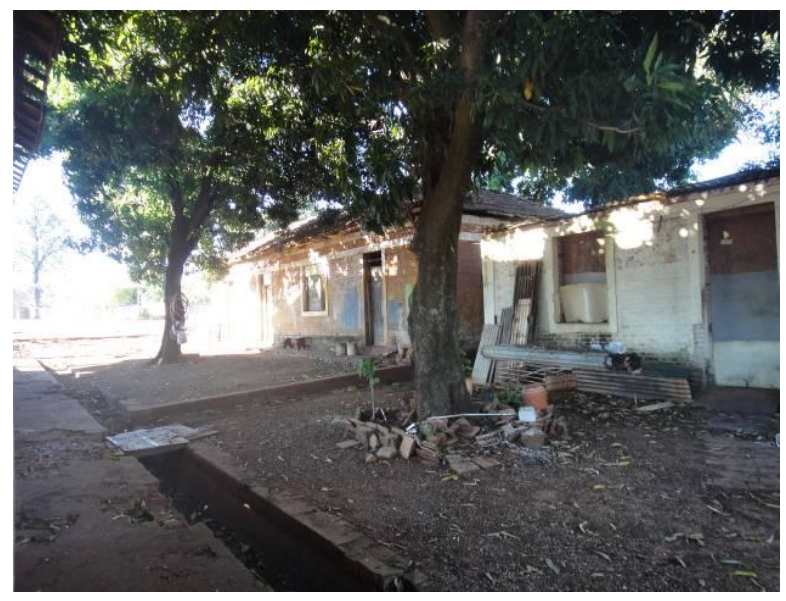

Foto 14. Oficina elétrica Fonte: Próprio autor.

\section{- A rotunda ou giradouro}

A rotunda foi construída no início da década de 1940, possui formato semicircular, contendo oficinas que dão suporte simultâneo a treze locomotivas, área de lavagem, depósito de peças, um girador para direcionar as locomotivas para as garagens de manutenção, formando um conjunto construtivo com ampla cobertura em telhas francesas que além do seu formato peculiar é identificada também pela logomarca da NOB no topo de sua face frontal (Fotos 15 e 16).

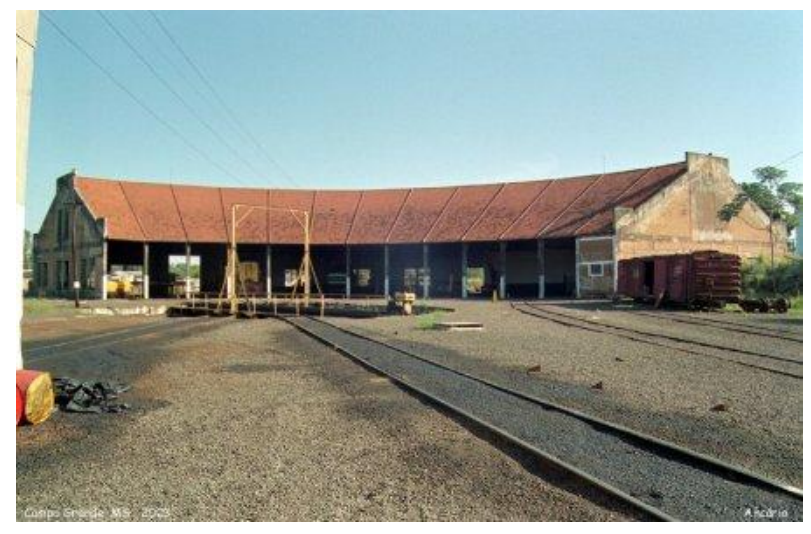

Foto 15. Rotunda década de 1990. Fonte: ARCA.

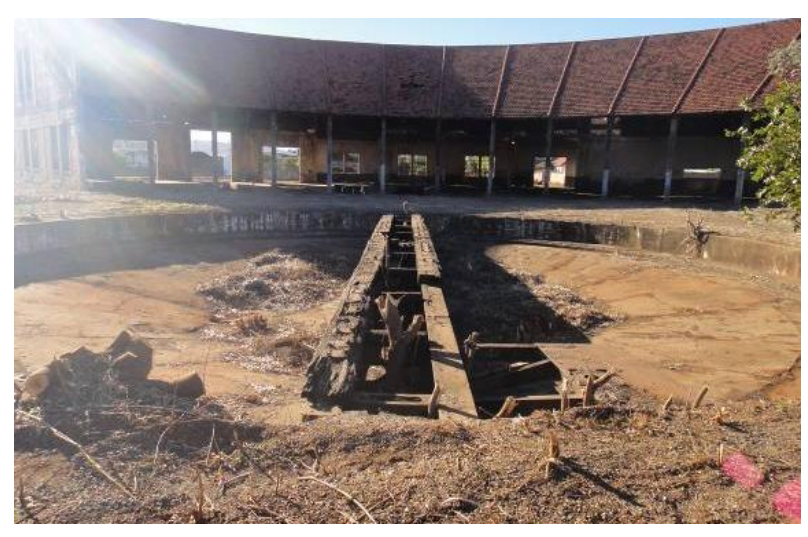

Foto 16. Rotunda 2012. Fonte: Próprio autor.

\section{b) Edificações residenciais}

Correspondem as antigas casas que funcionavam como moradia para os funcionários da ferrovia. Dividem-se em três grupos: casas de uso residencial operário, casas de uso residencial para funcionários intermediários e casas de uso residencial para funcionários graduados. 


\section{- Vila Ferroviária: A Rua Dr. Ferreira}

As construções das casas da Rua Dr. Ferreira datam dos anos de 1934 e 1939, foram construídas pela empresa Thomé \& Irmãos Ltda, ao todo são 59 imóveis, sendo 58 residenciais (30 do lado direito, sentido norte e 28 no lado oposto) e a já desativada Escola Estadual de Primeiro Grau Álvaro Martins Neto. O uso destas casas era para moradia dos operários da ferrovia, sua localização determina a proximidade que o trabalhador deveria ter com seu posto de trabalho. A rua fica ao lado da estação e à frente da esplanada e oficinas da ferrovia. A construção simples comparada às demais casas do complexo indicam certo controle social, que era característico dos projetos de habitação fabril daquele período no Brasil (FINGER, 2009).

As Casas da rua Dr. Ferreira (Fotos 17 e 18), estão implantadas de modo geminado e de construção simples, possuem terrenos de dimensões variáveis, porém o corpo central em todas as casas é o mesmo, com as seguintes características:

- Planta com 02 ou 03 quartos, sala e copa além do banheiro, em alvenaria;

- Piso dos quartos em assoalho e dos demais ambientes em cimento queimado tingido de vermelho;

- A cozinha, nos fundos ocupa quase toda a extensão lateral do terreno e a sua vedação em madeira na maioria das casas.

Ao longo dos anos, antes do processo de tombamento, as casas foram recebendo melhorias por parte de seus moradores, como ampliação de área construída no terreno, troca de janelas de madeira por janelas metálicas além de outras modificações na parte interna da casa como reforma de banheiros e modificação na divisão dos quartos e sala. As modificações exteriores trouxeram algumas mudanças visuais nas casas, porém não afetam a homogeneidade da vila, nem descaracterizam nas enquanto residências operárias sendo fácil o seu entendimento no complexo ferroviário.

A vila é considerada cartão postal da cidade, expressa o modo de vida na ferrovia e é extremamente importante para a memória ferroviária, pois sua construção e sua pavimentação de paralelepípedos representam uma ruptura no tempo, nela se "respiram ares" do início da modernização urbana campo grandense e principalmente a divisão social existente na cidade naquele momento. 


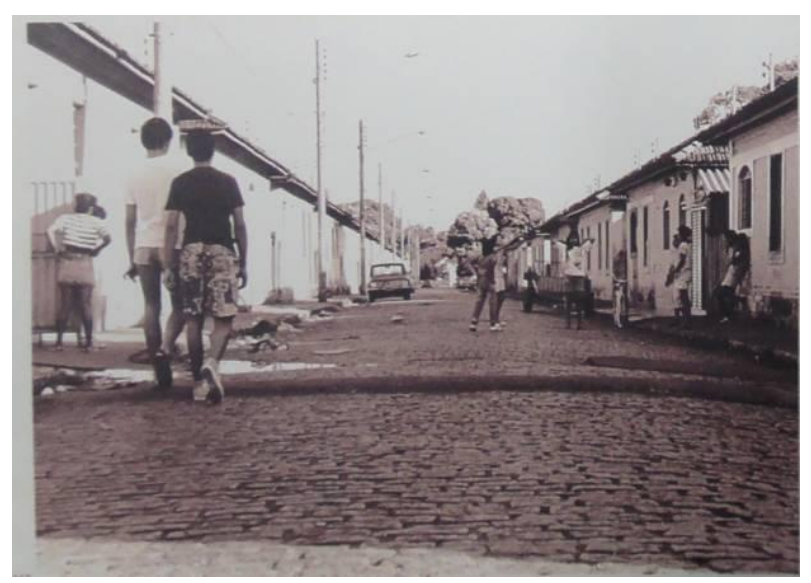

Foto 17. Rua Dr. Ferreira década de 1980/90. Fonte: ARCA.

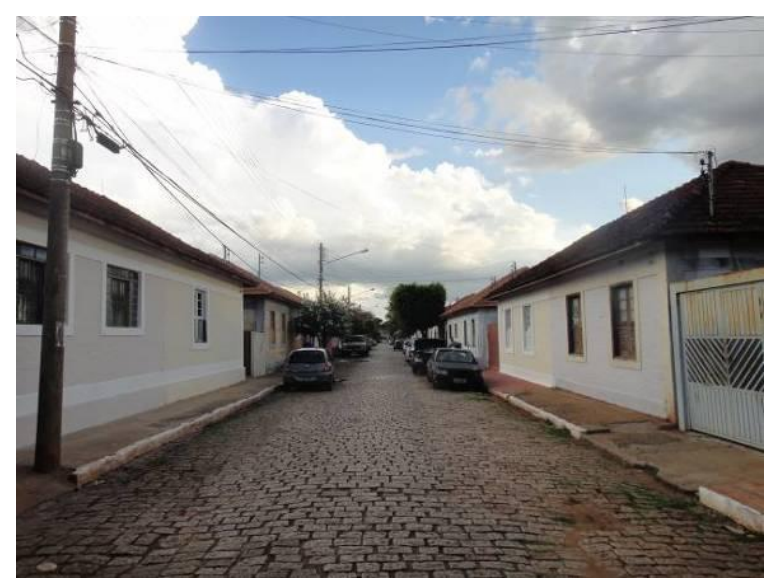

Foto 18. Rua Dr. Ferreira 2011 Fonte: Próprio autor.

Apesar de se tratar de um conjunto de moradias oriundas da ferrovia, hoje as casas não são só ocupadas por ex-ferroviários, algumas casas foram compradas por terceiros, e interessam a muitas pessoas devido ao fato de serem isentas de pagamento de IPTU, por possuírem localização central na cidade e por serem parte da historia de Campo Grande. Essa procura elevou os preços de venda das casas, que na época do leilão dos bens da ferrovia custaram entre $\mathrm{R} \$ 8$ e 20 mil reais dependendo do tamanho do lote, hoje os valores iniciais estão na faixa de $\mathrm{R} \$$ 80 mil reais.

\section{- Vila Ferroviária: A Rua dos Ferroviários}

A rua dos ferroviários (Fotos 19 e 20) também é considerada uma vila ferroviária, foi construída em período posterior a vila da rua Dr. Ferreira, datada da década de 1950. Sua função de uso também era de moradia para os operários da ferrovia, ao todo são 46 casas, quase todas de madeira. É também na rua dos ferroviários que se localiza a primeira casa de alvenaria da ferrovia em Campo Grande (Fotos 21 e 22), construída em 1920 para abrigar engenheiros que trabalharam na construção da NOB. É um edifício que possui características que o diferem de todas as residências de Campo Grande: possui um enorme terreno de 1.227, $48 \mathrm{~m} 2$ e uma área construída de 178,88 m2. No programa da edificação um escritório frontal com 21,0 m2, uma sala menor, outra maior, que abre porta para a varanda; três quartos grandes, uma copa, banheiro, cozinha e uma garage que faz parte do corpo da casa. A varanda em ferro trabalhado, guarda até hoje um padrão europeu típico da arquitetura ferroviária; as janelas e as molduras em argamassa são também elementos de arquitetura que a transformam em edifício único na Esplanada. O 
beiral em madeira é único no conjunto, sendo encontrado, apenas, no telhado que liga a estação ao armazém (ARRUDA, 2002).
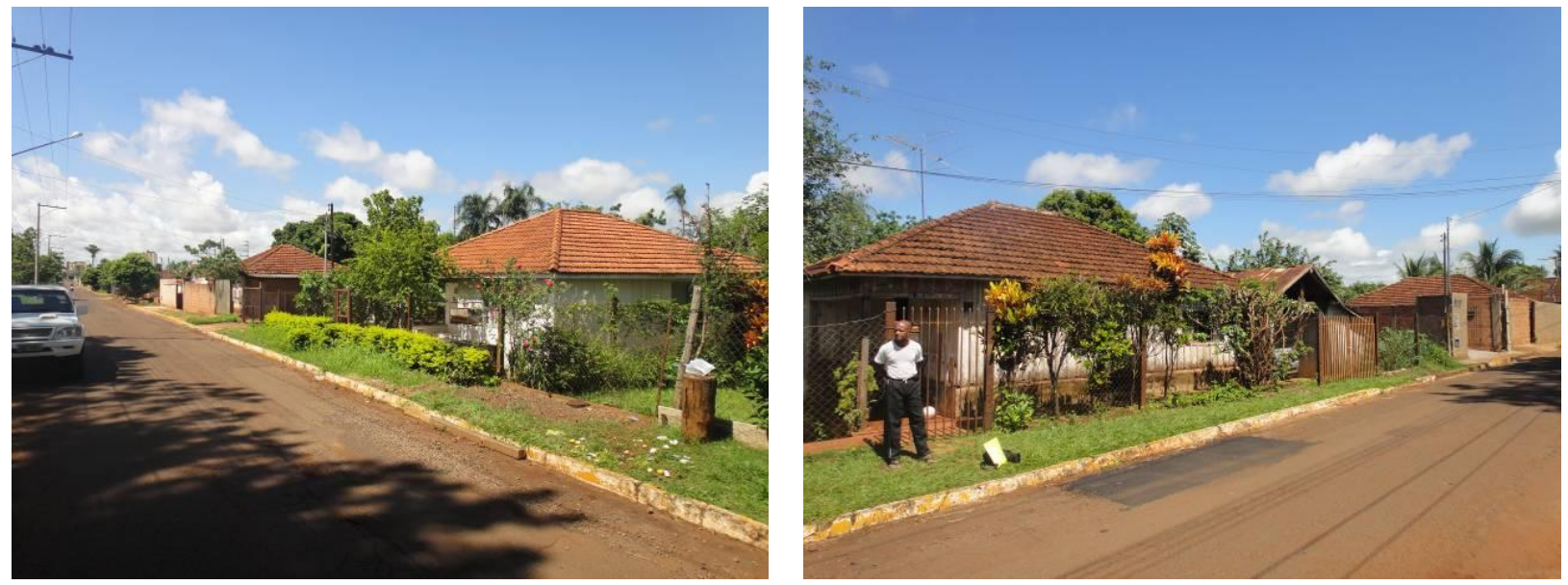

Fotos 19 e 20: Rua dos Ferroviários em 2013. Fonte: Próprio autor.
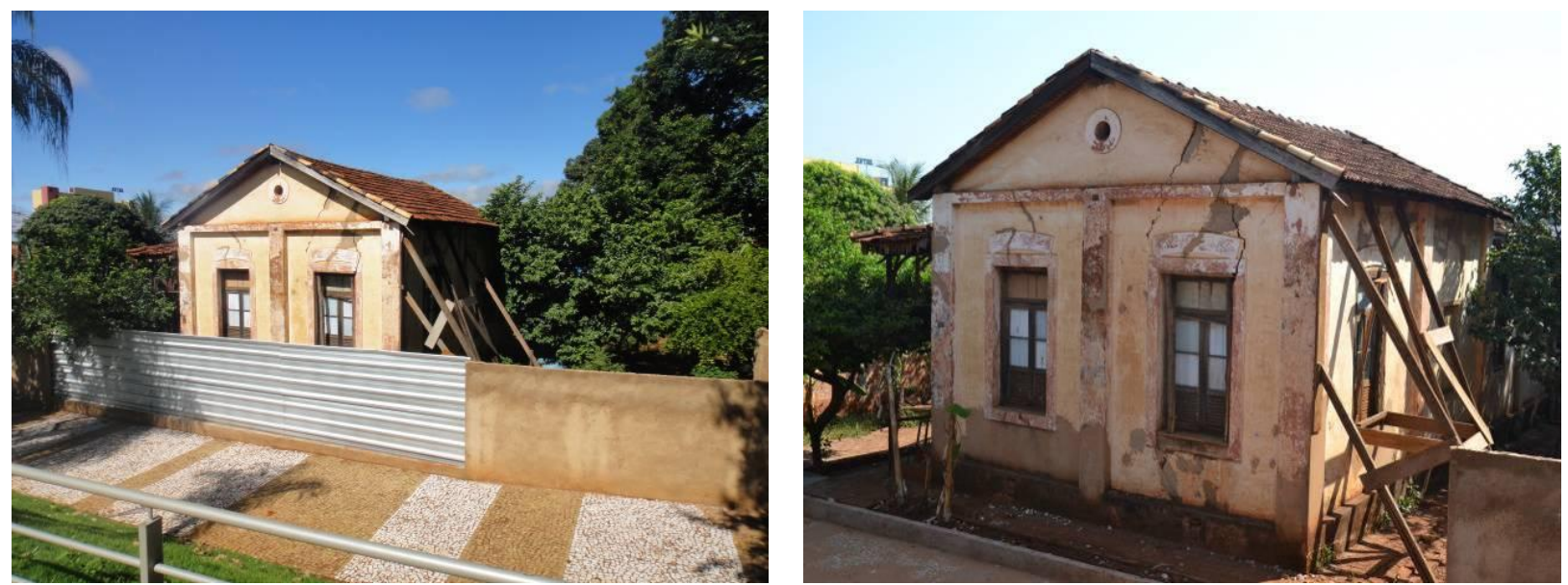

Fotos 21 e 22. Primeira casa de alvenaria do complexo ferroviário em Campo Grande em 2013. Fonte: Próprio autor e Minamar Junior, respectivamente.

A Rua dos ferroviários não recebeu nenhuma intervenção por parte dos órgãos responsáveis pela tutela destes bens tombados, sendo que uma das necessidades é a substituição do sistema de fossa por esgoto encanado, uma obra simples, porém sem estudos até o momento, como relata Haroldo Gonçalves, ex-ferroviário e morador desta rua.

A primeira casa de alvenaria da ferrovia em Campo Grande, como é possível observar nas fotos encontra-se escorada por madeiras, e ainda não recebeu nenhuma intervenção, demonstrando uma falha dos projetos de tombamento, pois é elemento marcante dentro do complexo ferroviário, relata através de sua arquitetura os padrões de construção dos prédios da 
ferrovia além de ter sido uma das primeiras casas de alvenaria de Campo Grande. Teve função importante no passado, pois serviu de moradia para os primeiros engenheiros que vieram trabalhar na NOB na cidade e consequentemente construíram o complexo ferroviário como conhecido hoje.

\section{- Residências dos funcionários intermediários}

Estas casas foram construídas para funcionários intermediários em 1930, apresentam arquitetura diferenciada em relação às casas operárias, com uma construção próxima as casas dos funcionários graduados, possuindo exemplares de lote único e algumas casas geminadas ao longo da Rua 14 de Julho (Fotos 23 e 24).
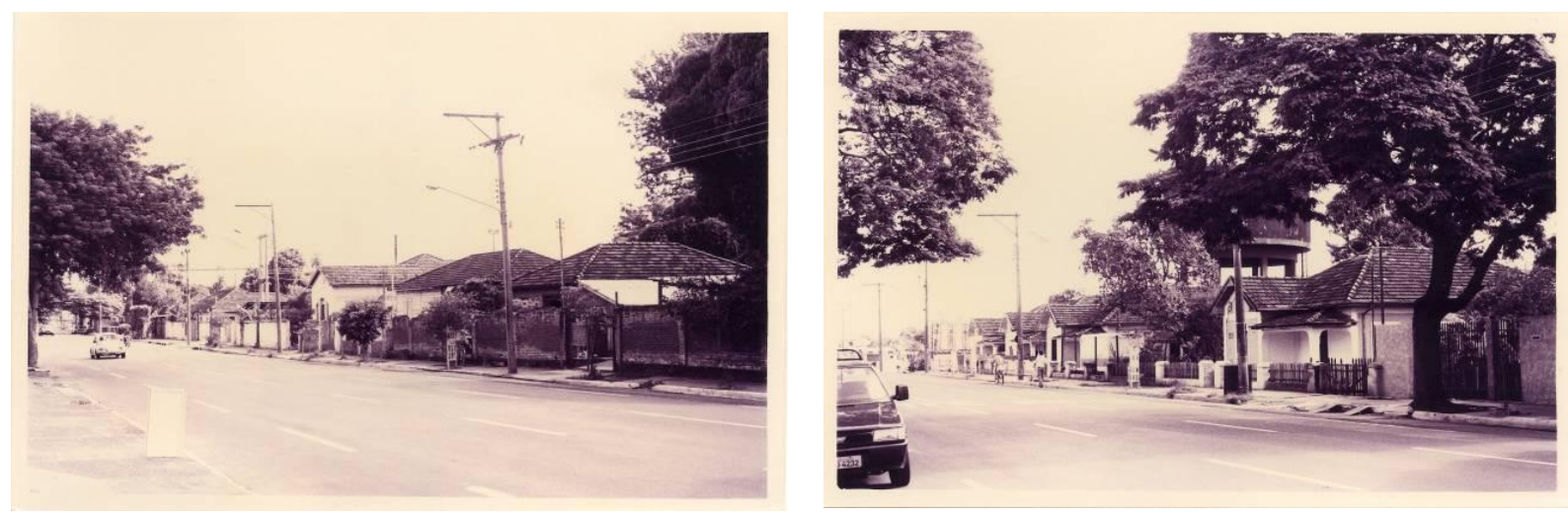

Fotos 23 e 24. Rua 14 de Julho - casas de funcionários intermediários s/d. Fonte: IPHAN.

Estas casas, mesmo não tendo recebido intervenções estão em bom estado de conservação, muitas ainda estão ocupadas por ex-ferroviários.

\section{- Residências de funcionários graduados: Av. Calógeras, Rua Dr. Temístocles e Rua General Mello}

São casas construídas também na década de 30 para o uso como moradia dos funcionários graduados da ferrovia, engenheiros, médicos advogados etc. que tinham cargos de maior expressão dentro da hierarquia institucional da NOB e posteriormente RFFSA.

Av. Calógeras (Fotos 25 e 26), Rua General Mello (Foto 27) e Rua Dr. Temístoles (Foto 28). 
Estas casas possuem uma arquitetura diferenciada em relação às demais moradias da ferrovia, todas as casas seguem um padrão da arquitetura europeia, sendo construídas todas em lotes isolados, com espaços variando de tamanha de acordo com a função do funcionário graduado. A este conjunto pertence a casa do chefe da estação (Foto 29), que se diferencia de todas as outras casas por seu estilo germânico e lote de maior tamanho que as demais casas, ao longo dos anos recebeu o apelido de "castelinho"pelos funcionários da ferrovia, o que reflete não só ao estilo de construção mas também a divisão social do trabalho, outra residência de destaque é a antiga casa dos engenheiros que também possui lote maior que as demais (Foto 30).
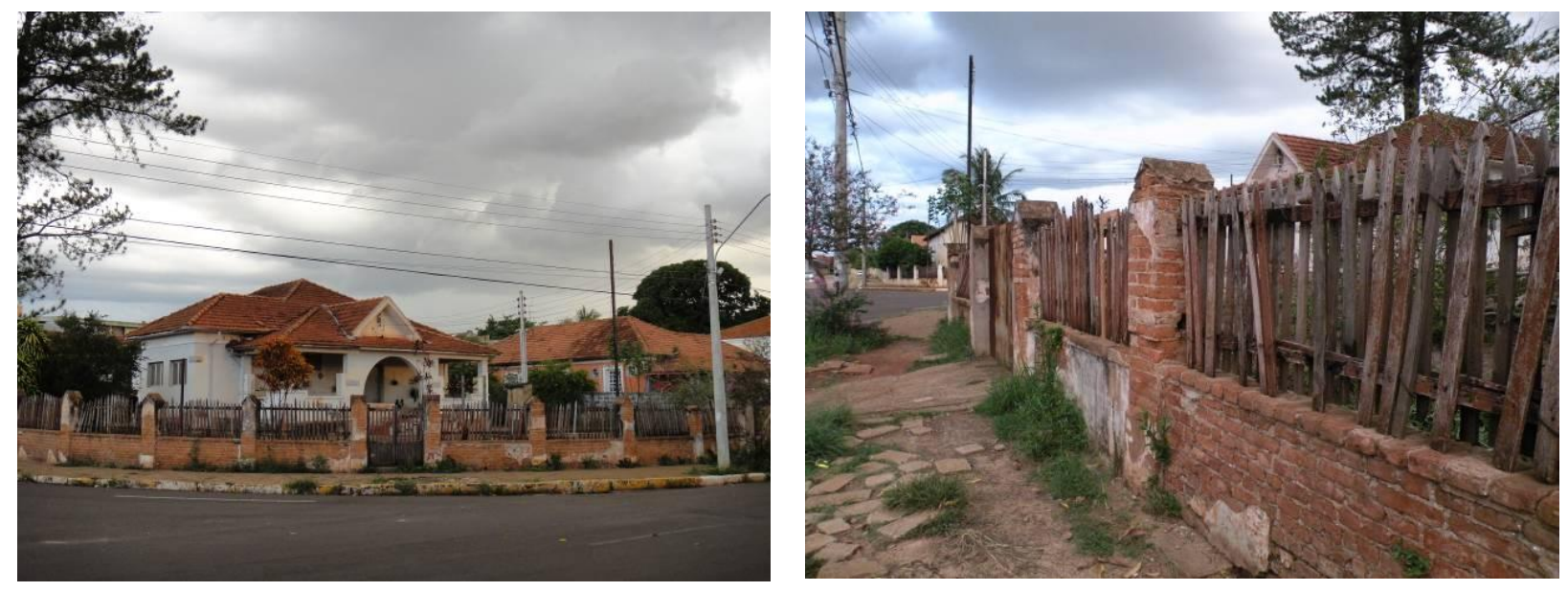

Foto 25 e 26. Casarão (uso residencial) na Av. Calógeras em frente à Estação Ferroviária em 2011. Fonte: Próprio autor.

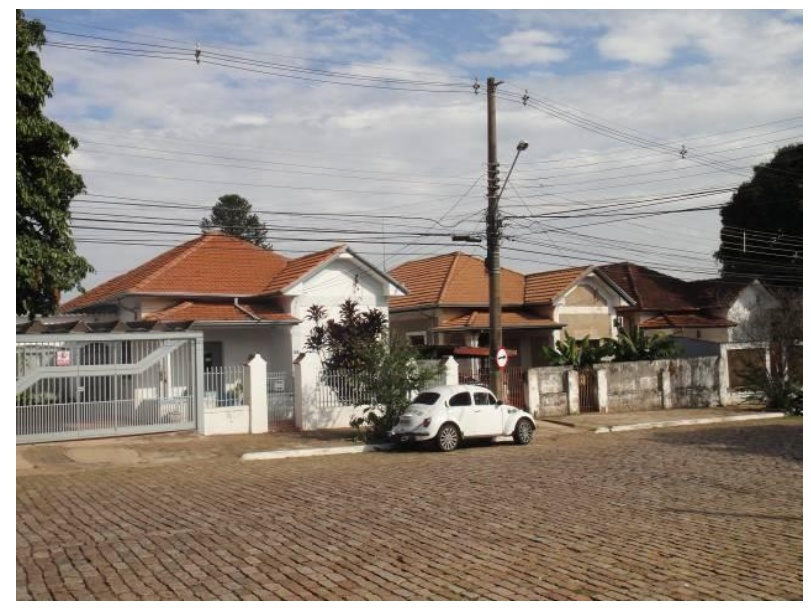

Foto 27. Casas na Rua Gal. Mello em 2012. Fonte: Próprio autor.

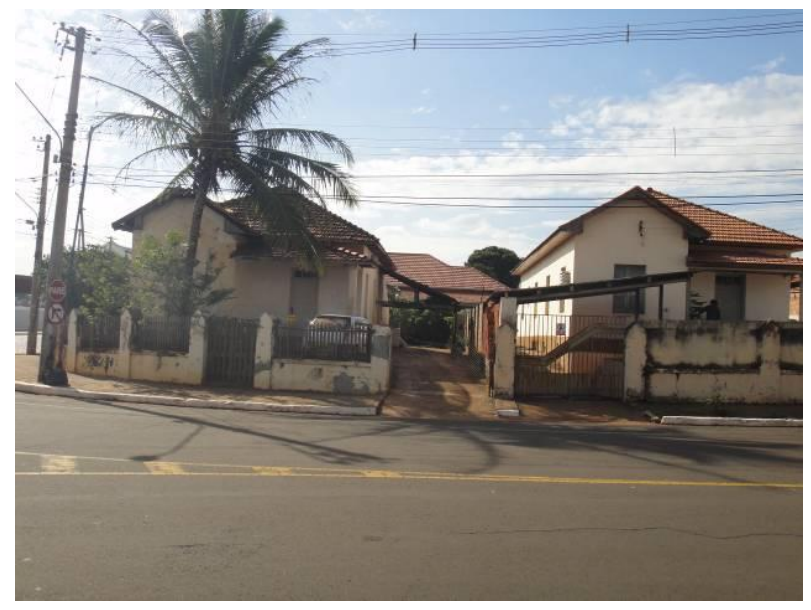

Foto 28. Casas na Rua Dr. Temístocles em 2012. Fonte: Próprio autor. 


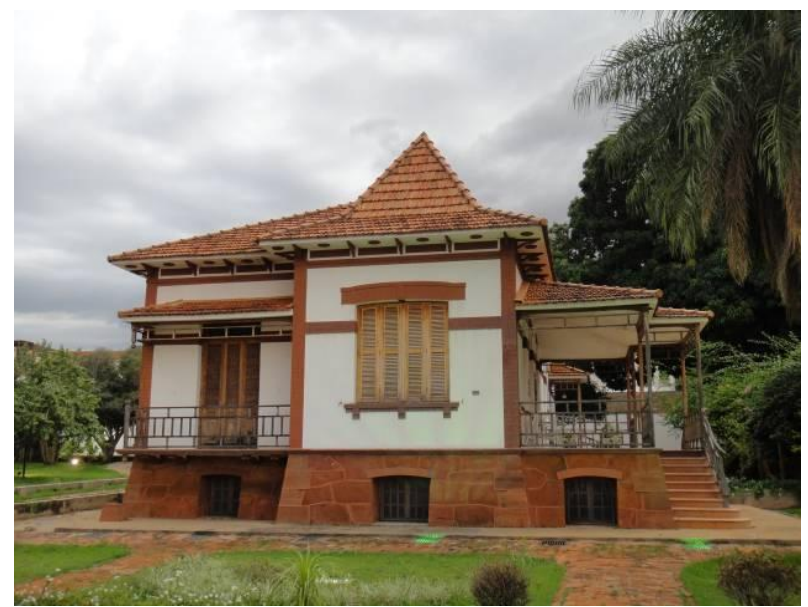

Foto 29. Castelinho em 2011. Fonte: Próprio autor.

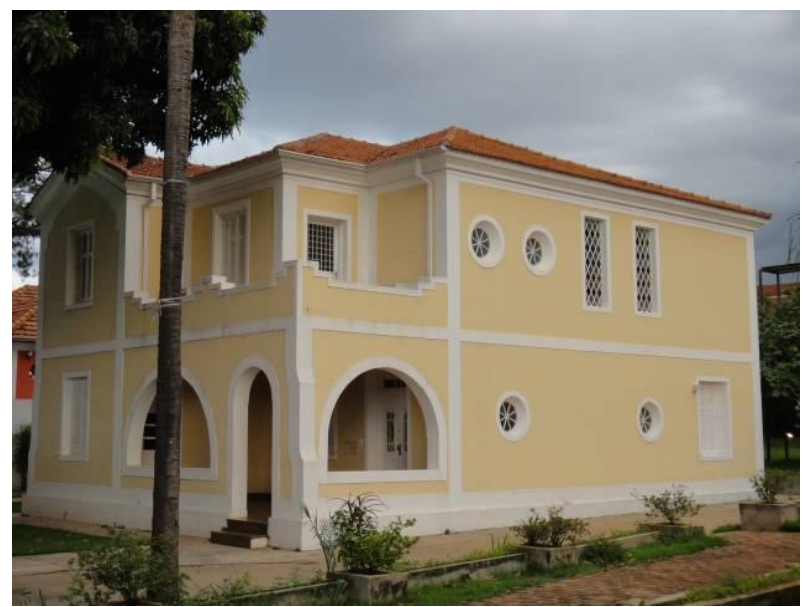

Foto 30. Casa dos Engenheiros em 2011. Fonte: Próprio autor.

Nas Fotos 29 e 30, os dois casarões estão localizados na Av. Calógeras em frente ao estacionamento da estação ferroviária, foram completamente reformados, e hoje recebem em sequencia o prédio da Foto 29, um gabinete da prefeitura, e o prédio da Foto 30, o Instituto Histórico e Geográfico do Mato Grosso do Sul IHGMS. O que na realidade é muito interessante, pois são as maiores residências do complexo ferroviário, com arquitetura mais destacada e maiores lotes, foram apropriados pelo governo municipal, e hoje atendem a um órgão municipal e outro estadual.

É interessante ressaltar até aqui a divisão espacial no complexo e a distinção de padrões construtivos e espaciais das habitações, mostrando as diferenciações entre as diversas camadas sociais de trabalho dentro da ferrovia. Assim, as residências administrativas, destinadas aos funcionários mais graduados, possuíam melhor padrão construtivo e espacial, eram inspiradas numa arquitetura europeia, isoladas em amplos lotes situados além do limite frontal do complexo ferroviário fornecido pela Rua Calógeras, sugerindo que se situavam no arranjo urbano da época, já as moradias dos operários possuíam padrões construtivos e espaciais mais simples, eram geminadas e de implantação posterior ao complexo, como que internalizadas a ele e afastadas do convívio com a cidade daquele momento.

\section{c) Equipamentos Urbanos}

Enquadram-se nesta tipologia dois elementos: a escola Álvaro Martin Neto e o clube Noroeste. 
A Escola Estadual de Primeiro Grau Álvaro Martins Neto, o "Batatinha" (Foto 31) como era chamado pelos ferroviários, construída em 1934 era a escola dos filhos da NOB e também atendia a população das redondezas.

O antigo Clube Noroeste (Foto 32) era o espaço de lazer dos ferroviários, nele aconteciam os bailes, festas além dos jogos de futebol, vôlei e bocha. Foi edificado em 1967, chegou a abrigar por um tempo a associação dos ferroviários aposentados na década de 90, porém na época da venda dos prédios da NOB foi comprado por pessoas sem ligação com a ferrovia e transformado em uma casa de shows, e hoje apenas sua localização tem alguma ligação com a memória ferroviária por aqueles que ali tinham seu centro de lazer aos finais de semana. O clube sempre foi palco para as disputas políticas, em época de eleição municipal e estadual, vários candidatos realizavam reuniões com os ferroviários objetivando apoio desta massa trabalhadora.

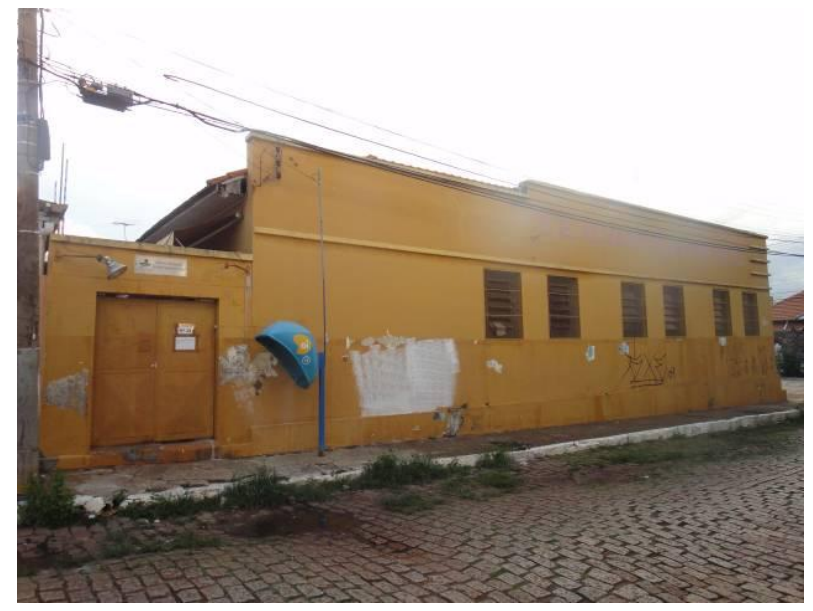

Foto 31. Escola Álvaro Martins Neto 2011. Fonte: Próprio autor.

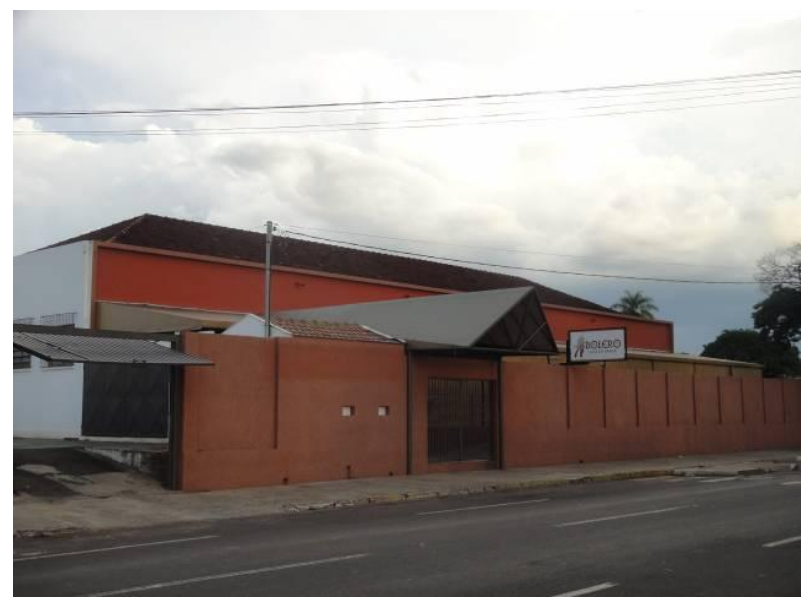

Foto 32: Casa de Dança Bolero, antigo clube Noroeste. Fonte: Próprio Autor.

O levantamento dos bens tombados da ferrovia em Campo Grande permite a compreensão do conjunto enquanto um verdadeiro complexo, com divisão específica dos espaços de trabalho, moradia e lazer, sendo perceptível a divisão social do trabalho a manutenção do funcionário próximo ao local de trabalho (caso do clube e escola para os filhos), impondo desta forma a lógica do capitalismo atuando com total controle sobre a vida do proletário.

A análise sobre os usos atuais, projetos de intervenção sobre os bens do complexo ferroviário e o estado de conservação assim como seu papel na urbanidade contemporânea estarão presentes no capitulo 3 deste trabalho. 


\title{
2.3 Os Níveis de Tombamento do Complexo Ferroviário da NOB em Campo Grande
}

No Brasil as ações sobre o patrimônio cultural ferroviário são recentes. Embora desde a década de 1980 houvesse tentativas inconclusas pela instituição de inventariar e estudar mais a fundo os bens ferroviários (GALVÃO JÚNIOR, 2007), um inventário amplo desses bens só ocorre a partir de 2007. Essa atenção especial está ligada as atribuições específicas para a preservação da Memória Ferroviária, por meio da promulgação da Lei nº 11.483/2007.

\begin{abstract}
Art. 9o
Caberá ao Instituto do Patrimônio Histórico e Artístico Nacional - IPHAN receber e administrar os bens móveis e imóveis de valor artístico, histórico e cultural, oriundos da extinta RFFSA, bem como zelar pela sua guarda e manutenção.

$\S 1^{\circ}$ Caso o bem seja classificado como operacional, o IPHAN deverá garantir seu compartilhamento para uso ferroviário.

§ 2o A preservação e a difusão da Memória Ferroviária constituída pelo patrimônio artístico, cultural e histórico do setor ferroviário serão promovidas mediante: I - construção, formação, organização, manutenção, ampliação e equipamento de museus,

bibliotecas, arquivos e outras organizações culturais, bem como de suas coleções e acervos; II - conservação e restauração de prédios, monumentos, logradouros, sítios e demais espaços oriundos da extinta RFFSA. (BRASIL, Lei $\left.\mathrm{n}^{\circ} 11483,2007\right)$.
\end{abstract}

Esta lei delegou ao Iphan a responsabilidade de zelar por todo o equipamento e instalações da antiga malha da RFFSA sendo estes itens reconhecidos por sua importância como patrimônio.

O enfoque no patrimônio ferroviário resultou na criação de uma Coordenação Técnica em 2008, com o intuito de ampliar o conhecimento, promover discussões e estabelecer procedimentos para lidar com as novas leis e decretos. Neste sentido, o IPHAN vem realizando o inventário de conhecimento dos bens ferroviários (materiais), apesar de, segundo o IPHAN (2012), ter sido catalogado mais de seis mil edifícios, a investigação consiste no estudo preservação e usos - dos 168 bens disponibilizados em sua página na internet (CASTRO; MONASTIRSKY, 2013).

Esta iniciativa do Iphan apontou de forma positiva para uma nova forma de promoção dos bens da ferrovia RFFSA, o que é muito importante para a memória ferroviária nacional e indica um maior interesse do Estado em preservar sua história elevando as questões sobre o patrimônio ferroviário ao mesmo dos demais patrimônios nacionais. 
No plano regional, antes do decreto de 2007, o patrimônio ferroviário de Campo Grande recebeu tutela municipal em 1996 e estadual em 1997.

Estes tombamentos referem-se ao conjunto dos bens da ferrovia enquanto sítio histórico, e descrevem os elementos que o compõem assegurando que sua integridade seja mantida.

O complexo ferroviário em Campo Grande tem sua importância atestada pela primeira vez através do tombamento municipal com o Decreto n³249, de 13 de maio de 1996.

Segundo o tombamento municipal, o complexo ferroviário da NOB compreende; Rua Dr. Ferreira; os imóveis e demais edificações localizados na Rua dos Ferroviários em toda a sua extensão; o imóvel localizado na Rua Antônio Maria Coelho no perímetro entre a Rua dos Ferroviários e Avenida Calógeras; os imóveis de número 2960, 2980, 3002 e 3018, localizados na Avenida Calógeras em frente à Estação Ferroviária, entre a Avenida Mato Grosso e a Travessa Dr. Temístocles. Os imóveis de números 15, 35, 49, 64 e 67 localizados na Travessa Dr. Temístocles; os localizados na Rua General Mello no perímetro entre a Rua Dr. Ferreira e a Avenida Calógeras; os imóveis localizados na Rua 14 de Julho no perímetro compreendido entre a Rua Eça de Queiroz e Rua Dr. Ferreira; e os imóveis que compõem a Estação Ferroviária de Campo Grande ${ }^{3}$.

O tombamento municipal estabelece através da lei municipal $\mathrm{N}^{\circ} 3249 / 96$ :

Art. $2^{\circ}$ - Fica proibido demolir ou alterar a Estação Ferroviária, suas dependências internas e externas, a sua fachada e seu estilo arquitetônico.

Art. $3^{\circ}$ - Fica proibido demolir ou alterar as fachadas e telhados das casas da Vila Noroeste, localizadas na Rua Doutor Ferreira.

Parágrafo Único - As dependências internas destas casas podem ser reformadas ou alteradas, desde que não danifiquem os telhados e fachadas originais.

Art. $4^{\circ}$ - As casas da Rua 14 de Julho e Rua dos Ferroviários pertencentes ao Patrimônio Histórico podem ser reformadas, desde que mantenham a originalidade.

Art. $5^{\circ}$ - Fica proibido remover os paralelepípedos da Rua Doutor Ferreira, da Rua General Mello e Avenida Calógeras em frente a Estação Ferroviária, bem como alterar seu traçado ou aplicar lama asfáltica.

${ }^{3}$ Art 1 da Lei LEI No 3249/96, disponível em: https://www.leismunicipais.com.br/a/ms/c/campogrande/lei-ordinaria/1996/324/3249/lei-ordinaria-n-3249-1996-dispoe-sobre-o-tombamento-dositio-historico-localizado-na-vila-noroeste-estacao-ferroviaria-e-nas-ruas-14-de-julho-rua-dosferroviarios-travessa-dr-temistocles-e-na-rua-dr-ferreira-pertence-1996-05-13.html, acesso em 12 de dezembro de 2013. 
Art. $6^{\circ}$ - As Empresas de Saneamento, Energia Elétrica e Telefônica, quando necessitarem executar alguma obra no local, deverão comunicar com antecedência à Administração Municipal, para que proceda a fiscalização quanto à inalteração do patrimônio histórico e, ao término da obra, deverão reconstituir a originalidade do Patrimônio Histórico.

Art. $7^{\circ}$ - A Escola Estadual de $1^{\circ}$ Grau Álvaro Martins Neto integra o Patrimônio Histórico, devendo ser mantida sua originalidade.

Art. $8^{\circ}$ - É isento de pagamento de IPTU os imóveis integrantes do Patrimônio Histórico ora tombado, conforme a regra do art. $2^{\circ}$, inciso II da Lei ${ }^{\circ} 2.786$, de 27/12/90. (que altera dispositivo do Código Tributário do Município).

Art. $9^{\circ}$ - Esta Lei entra em vigor na data de sua publicação, revogando-se as disposições em contrário.

O tombamento estadual por sua vez, através da lei nº1735, de 26 de março de 1997, foi uma extensão do ocorrido em Campo Grande pelo poder municipal, porém diz respeito apenas as estações da extinta ferrovia e seu entorno imediato em todas as cidades as quais a NOB fez parte no Mato Grosso do Sul com exceção ao complexo ferroviário de Campo Grande que recebeu os mesmos atributos do tombamento municipal. Esta lei não esta disponível na internet e quando realizada a pesquisa de campo, não foi possível a consulta à mesma, pois o acervo da secretaria de cultura estadual não estava aberto ao público, a informação citada à cima é relativa à leitura de alguns textos disponíveis online de caráter informativo da Fundação de Cultura Municipal do município ${ }^{4}$.

Por parte do IPHAN, o tombamento do complexo ferroviário da antiga Estrada de Ferro Noroeste do Brasil em Campo Grande, foi aprovado apenas em dezembro de $2009^{5}$, período longo de espera, no qual várias ações já haviam sido realizadas pelo poder municipal.

Os estudos de tombamento do complexo ferroviário tiveram inicio em $2005^{6}$, conforme o dossiê foram realizadas duas visitas técnicas cada uma com um parecer sobre a situação dos bens da ferrovia e a importância da mesma para a cidade.

${ }^{4}$ Disponível para consulta http://eventosfundac.blogspot.com.br/2012_10_01_archive.html, acesso em janeiro de 2012.

${ }^{5}$ Disponível para consulta, http://portal.iphan.gov.br/portal/montarDetalheConteudo.do?id=14883\&sigla=Noticia\&retorno= detalheNoticia, acesso em 13 de junho de 2011. 
Os estudos foram realizados por dois técnicos do Iphan, sendo o primeiro estudo feito pelo Historiador Adler Homero Fonseca de Castro e o segundo pelo Arquiteto Fábio Rolin.

O primeiro parecer técnico apresenta uma análise rápida sobre as condições dos bens naquele momento, foi realizada uma do estado de conservação dos mesmos, caracterizando-os ao final como em situação de depredação e abandono, com exceção da Estação e do armazém, que receberam um tratamento de fachada por parte da prefeitura.

O segundo parecer técnico traz além da análise sobre as condições dos bens similar ao primeiro parecer, um trabalho de resgate histórico do complexo ferroviário em Campo Grande, relatando sua importância histórica, econômica, política e social para o município.

Ponto de destaque em ambos relatórios diz respeito a feira central, elemento externo a história do complexo ferroviário que foi inserido na esplanada da ferrovia pelo poder municipal, sobre a qual os técnicos se referem como elemento estranho que descaracteriza o complexo ferroviário e que sua estrutura não conversa com a paisagem ferroviária, porém mesmo co estes problemas chegaram ao consenso que a mesma não impede a percepção do conjunto como um complexo ferroviário.

Outro ponto de destaque no dossiê diz respeito ao pedido de impugnação que a prefeitura fez ao tomar conhecimento que o sitio histórico da ferrovia estava em estudo de tombamento por parte do Iphan, visto que algumas intervenções urbanas já haviam sido realizadas e a prefeitura pretendia expandir estas intervenções a região do complexo ferroviário. A Impugnação foi refutada pelo Iphan, visto que muitas obras realizadas pela prefeitura contribuíram com a descaracterização do conjunto ferroviário, a exemplo disso a feira central e a retirada de parte dos trilhos da cidade.

Analisando o tombamento nas três esferas, eles são semelhantes na questão de preservar a importância que a ferrovia teve para o desenvolvimento de Campo Grande, porém no caso municipal o tombamento traz a questão de valorização do centro através do discurso do patrimônio como âncora deste processo, visto que as ações que foram realizadas e o próprio pedido de impugnação do estudo de tombamento por parte do Iphan demonstram o interesse apenas em realizar intervenções urbanas sem muita alusão à memória ferroviária.

${ }^{6}$ IPHAN -Instituto do Patrimônio HIstórico Nacional. Dossiê de Tomabamento do Complexo Ferroviário de Campo Grande. Rio de Janeiro, 2009. 
Por parte do Iphan, o dossiê reforça a importância do complexo ferroviário na formação espacial urbana de Campo Grande, além da urgência em tombar o mesmo, antes que novas ações por parte do poder municipal fossem realizadas. No documento esta descrito de forma clara e objetiva a relação entre a ferrovia como elemento fundamental ao desenvolvimento do município, sendo este o principal argumento pedindo o tombamento do complexo ferroviário. 


\section{Capítulo 3: Entre Memória e Valorização: Uma Análise Sobre o Processo de Revitalização Proposta ao Complexo ferroviário em Campo Grande-MS.}

Neste capítulo será realizada uma análise sobre as intervenções no patrimônio ferroviário, buscando compreender o intuito destas ações, investigando suas propostas e o que de fato foi realizado nos bens. Para tanto como base dessa investigação levaremos em consideração, como afirma Kuhl (2008), que na questão da preservação há um apelo voltado para o valor de uso, o reconhecimento de determinado bem pelo seu valor cultural servindo como suporte do conhecimento e da memória coletiva. Entende-se então que o valor de uso está diretamente ligado à identidade com o lugar, pois, remete a apropriação por parte de grupos da sociedade aos locais que servem como instrumentos de legitimação de sua identidade.

Outra questão abordada neste capítulo é a relação das intervenções no complexo com a memória coletiva, tendo como suporte entrevistas realizadas nos trabalhos de campo, a análise sobre as intervenções realizadas no complexo ferroviário e a percepção do público em relação ao patrimônio ferroviário e sua tutela, ou seja se o que está (e foi) sendo realizado remetem a importância que a ferrovia NOB teve para a cidade de Campo Grande.

Por último, pretende-se analisar o papel da ferrovia como ponto central da constituição da memória urbana ou memória da cidade, analisando como esta memória vem sendo tratada no processo de revitalização vigente em Campo Grande.

\subsection{As intervenções Realizadas no Complexo Ferroviário de Campo Grande-MS}

\section{-Estação Ferroviária}

O bem recebeu investimento do Iphan por meio do acordo do PAC Cidades Históricas em 2011 no para recuperação e readequação visando abrigar o Centro de Documentação e Referência da ferrovia em Mato Grosso do Sul.

Os serviços de recuperação consistiram em retirar algumas ampliações na cobertura construídas sem critério, retorno de algumas esquadrias retiradas da fachada, recomposição dos beirais (lambrequins), recuperação do mural do saguão por meio de decapagem pictórica, retorno das 04 aberturas dos guichês e dos elementos vazados do muro. Durante a execução da obra no 
espaço do bar/lanchonete, apoio e cozinha foi encontrado embaixo do piso cerâmico vermelho, alguns ladrilhos hidráulicos, ocasionando a recuperação deste piso nos espaços citados ${ }^{7}$.

Nos locais onde o telhado era em telha cerâmica francesa, todas as peças foram retiradas, limpas e antes de recolocadas foi instalada manta de alumínio para melhorar o conforto térmico dos ambientes. Com relação ao telhado da plataforma, a cobertura em telha de fibrocimento foi retirada e substituída por telha de aço térmica.

O serviço de pintura interno e externo foi realizado após a prospecção pictórica e exploratória, sendo a escolha das cores dos ambientes referentes ao mesmo período. $\mathrm{Na}$ plataforma, os trilhos e tesouras que haviam recebido diversas camadas de pintura ao longo dos anos foram recuperados e pintados com verniz deixando o material aparente (IPHAN, 2009). Foi recuperado também o relógio do corpo principal e instalado novamente a campainha na plataforma. Ainda para o portão em ferro fundido que outrora tivera sua logomarca da NOB roubada foi realizada recomposição de um novo elemento com as mesmas dimensões e instalada novamente no portão. O bem ainda sofreu alterações para readequar seu acesso de acordo com a norma de acessibilidade vigente, recebendo ainda elementos de proteção contra incêndio e pânico, instalação de guarda corpo ao longo da plataforma, instalação de hidrantes, mangueiras de incêndio, extintores e campainhas.

Para valorização da edificação o mesmo recebeu sistema de alarme monitorado, todos seus ambientes foram climatizados e foi instalada iluminação ornamental da fachada, nos pilares de ferro da plataforma e nos beirais. Dentre os serviços de readequação foi realizada a demolição de algumas paredes identificadas como construção mais recentes e ainda foi construído um novo bloco para abrigar o espaço multiuso com a utilização de materiais diferenciados.

A obra foi concluída em dezembro de 2011 e mesmo após todo este processo a estação se encontra fechada, o que demonstra que o processo de revitalização não teve um planejamento de uso contínuo mais efetivo além da proposta, mostrando a fragilidade das intervenções no patrimônio que muitas vezes é apenas de "casca", que não busca inserir o bem, dando- lhe um novo sentido na atualidade. Sendo assim questiona-se o uso do termo "revitalização", pois o bem foi reformado e não foi reinserido ao cotidiano da cidade, sendo passível apenas para fruição

${ }^{7}$ Disponível em: http://www.campograndenews.com.br/cidades/capital/resguardo-da-historiainaugurada-a-revitalizacao-da-estacao-ferroviaria, acesso em março de 2013. 
visual aos visitantes que passa pela região com destino a feira central, dessa forma a estação que sempre teve um papel central para Campo Grande se tornou coadjuvante em seu próprio berço.

\section{-Armázem}

O armazém hoje é utilizado como espaço para eventos, teve sua estrutura reforçada e suas características originais preservadas. O espaço esta em uso desde o tombamento municipal, porém seu uso contínuo se deu após a inserção da feira central no complexo ferroviário.

\section{-Escritório dos Engenheiros}

A edificação recebeu investimento no ano de 2009 pelo próprio Iphan/MS para recuperação e readequação para sediar a Superintendência do órgão em Mato Grosso do Sul. Os trabalhos tiveram a duração de 195 dias e compreenderam recuperação de pisos de tacos e esquadrias de ferro e de portas de madeira, recuperação do telhado e cobertura, descupinização, prospecção pictórica, paisagismo, pintura e readequação de todas as instalações elétricas, hidráulicas e hidrossanitárias, além de adaptação dos espaços internos para a disposição de novo uso de acordo com as necessidades de trabalho na Superintendência.

\section{- Galpões e Esplanada}

Estes espaços tiveram importância fundamental durante os anos de funcionamento da ferrovia, abrigavam funções específicas para o trabalho na ferrovia. O pernoite servia de dormitório para os maquinistas e funcionários que estavam de trabalho fora de suas cidades, as oficinas tinham a finalidade para pequenos reparos elétricos e mecânicos, como tornearia por exemplo. Estes espaços de grande importância para a memória do trabalho na ferrovia se encontram abandonados sem nenhuma ação de tutela mesmo sendo tombados nas três esferas do poder, o que coloca a questão de que os órgãos de patrimônio não priorizaram a memória do trabalho na definição de suas ações de recuperação e destinação de uso do complexo ferroviário.

Ainda sobre a esplanada, é importante ressaltar que dentre as ações do poder municipal, houve a instalação da feira central ocupando grande parte deste espaço.

Um ponto que evidencia esta questão é a inserção da feira que traz uma desconexão ao complexo ferroviário, pois descaracteriza o espaço trazendo elementos que não dialogam com a história local. Esta intervenção foi realizada pela prefeitura Municipal sendo entregue no ano de 
2002. Segundo estudo apresentado pelo arquiteto/técnico da $18^{\text {a }}$ Superintendência Regional do IPHAN em Campo Grande/MS - Fábio Rolim, para o processo de tombamento pela esfera federal, a homogeneidade visual do complexo passou a sofrer ruídos após a construção deste elemento estranho no complexo ferroviário e coloca que a posição $18^{\mathrm{a}}$ SR é contrária a inserção da feira neste espaço, mesmo que de forma simbólica já que na época de sua construção o tombamento federal ainda não havia acontecido.

Apontando esta falha por parte das intervenções realizadas pelo poder municipal, que ao invés de promover a salvaguarda dos bens da extinta ferrovia e de sua memória, entende-se hoje que a inserção da feira, na realidade suprimiu este espaço antes caracterizado pelo trabalho na ferrovia, substituindo seu significado por uma nova memória não ferroviária.

\section{- A rotunda ou giradouro}

Ponto importante para a discussão sobre a preservação da memória ferroviária na cidade discute-se a não revitalização da rotunda enquanto paradoxo frente à revitalização de bens com maior destaque da ferrovia, como a Estação. Articula-se aqui a contradição entre memória oficial e memória do trabalhador, entendida como em segundo plano no processo de revitalização do complexo ferroviário na cidade. Fato este que pode ser justificado salvo as diferenças entre os grandes centros e as cidades de médio-grande porte como Campo Grande, segundo Scifoni e Nascimento:

“... que na metrópole contemporânea em constante redefinição de usos, de formas e conteúdos da urbanização, os poucos lugares que ainda se mantém e que retém a memória de uma experiência social de vida operária, são aqueles que correm maiores riscos de desaparecimento, transformados por iniciativas de revalorização urbana, conduzidas e orientadas por políticas públicas e pela ação do mercado imobiliário.” (SCIFONI; NASCIMENTO, 2012, pág.2)

\section{- Vila Ferroviária: A Rua Dr. Ferreira}

Sobre os projetos de intervenção por parte do estado e do município foi realizado uma única ação por volta de 1997-98, quando os paralelepípedos foram rearranjados, ao longo dos anos o excesso de circulação de veículos pesados ocasionou deformidade nas ruas recobertas por este tipo de pavimento.

O IPHAN vem atuando controlando as intervenções nas casas através de fiscalizações que ocasionam em embargo de obras que não estejam dentro dos padrões e normas estabelecidas com 
estudo prévio de intervenção. Para qualquer intervenção na estrutura ou fechada das casas o órgão deve ser consultado.

Outra ação importante deste órgão foi o projeto Coral Tudo de Cor que teve início em dezembro de 2011 sendo concluído em maio de 2012. O projeto é uma parceria entre a Prefeitura Municipal de Campo Grande, através da Fundação Municipal de Cultura (Fundac), a Coral Tintas e a Superintendência do Iphan em Mato Grosso do Sul. Foi desenvolvido em quatro etapas: a primeira foi a "seleção", onde a vila foi escolhida pelo seu valor histórico, arquitetônico e pela relevância do projeto para as pessoas que ali moram; a segunda foi o "diálogo", etapa muito importante, pois foi o momento de discussão da cultura e tradição local juntamente com a opinião de todos, com conversas e combinados entre a liderança local, autoridades e moradores e foi definido um padrinho para o projeto; a terceira etapa foi a "transformação", onde foram oferecidos treinamentos para aprendizes e pintores locais, que em mutirão com voluntários da comunidade e funcionários da Coral tintas, prepararam e pintaram as casas de acordo com o que foi discutido na etapa anterior; a última etapa foi a "celebração", com presença de músicos, autoridades e moradores, é a hora da comemoração e a formatura dos aprendizes.

A sugestão pela Vila dos Ferroviários foi devido ao seu valor histórico e arquitetônico, visto que foram casas construídas na década de 30 para os funcionários da RFFSA.

\section{- Vila Ferroviária: A Rua dos Ferroviários}

A Rua dos ferroviários não recebeu nenhuma intervenção por parte dos órgãos responsáveis pela tutela destes bens tombados, sendo que uma das necessidades é a substituição do sistema de fossa por esgoto encanado, uma obra simples, porém sem estudos até o momento, como relata Haroldo Gonçalves, ex-ferroviário e morador desta rua.

A primeira casa de alvenaria da ferrovia em Campo Grande, como é possível observar nas fotos encontra-se escorada por madeiras, e ainda não recebeu nenhuma intervenção, demonstrando uma falha dos projetos de tombamento, pois é elemento marcante dentro do complexo ferroviário, relata através de sua arquitetura os padrões de construção dos prédios da ferrovia além de ter sido uma das primeiras casas de alvenaria de Campo Grande. Teve função importante no passado, pois serviu de moradia para os primeiros engenheiros que vieram trabalhar na NOB na cidade e consequentemente construíram o complexo ferroviário como conhecido hoje. 


\section{- Residências dos funcionários intermediários}

Possuem atualmente em sua maioria o uso residencial e estão em bom estado de conservação, duas residências foram transformadas em restaurantes pelos próprios proprietários (ex-ferroviários), aproveitando a forte atração que a região obteve após a inserção da feira central no complexo ferroviário.

Não receberam intervenções de nenhum nível de tombamento, mostrando mais uma vez a ineficiência do tombamento realizado, neste caso de todas as esferas.

\section{- Residências de funcionários graduados: Av. Calógeras, Rua Dr. Temístocles e Rua} General Mello

Estas residências possuem usos residenciais e nos exemplares citados no capítulo anterior, possuem funções públicas, sendo o castelinho convertido em gabinete da Prefeitura, e a casa dos engenheiros abriga o instituto Histórico e geográfico do MS.

Uma situação que merece destaque nesta tipologia de imóveis, e uma casa (Foto 33 e 34) localizada em frente à estação ferroviária, que originalmente foi concebida como residência de funcionários graduados da ferrovia, sendo posteriormente convertida em escritório. Atualmente é residência de uma família de ex-ferroviários, porém o imóvel esta totalmente degradado no seu exterior, inclusive sua calçada esta totalmente quebrada, se tratando de um imóvel que contempla o mesmo espaço que a estação é um absurdo que nenhuma ação tenha sido tomada sobre seu estado.
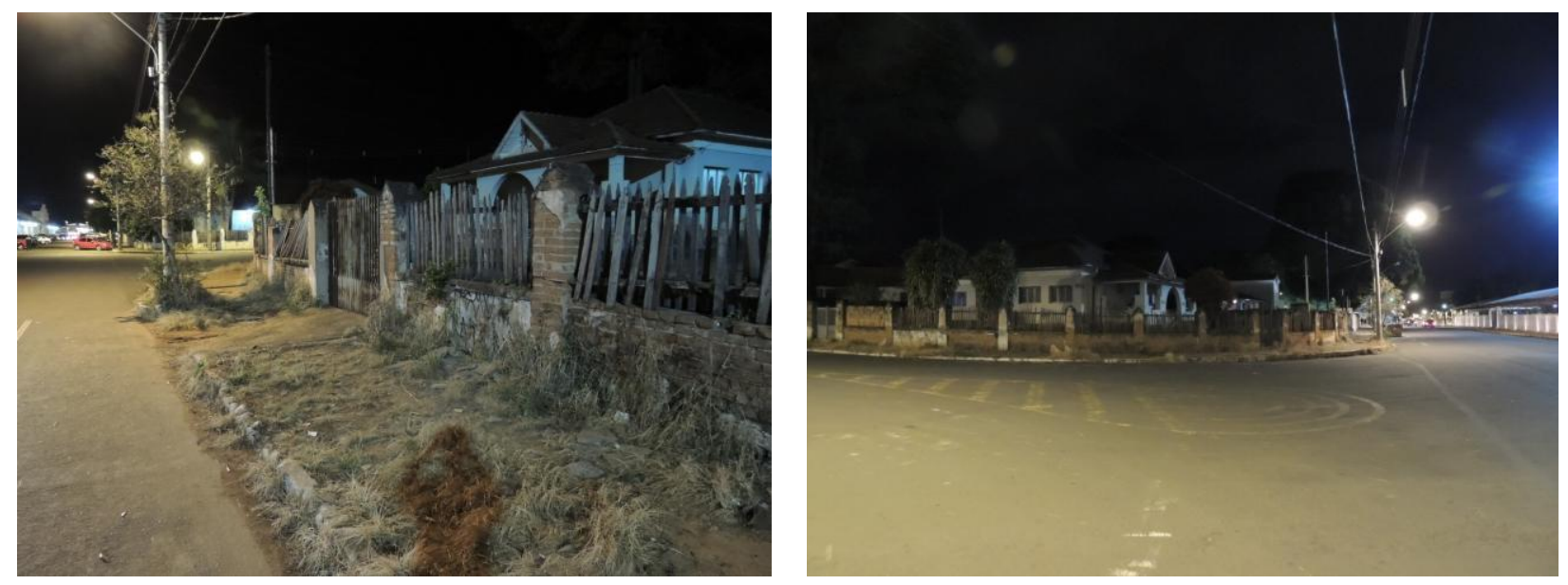

Foto 33 e 34. Casarão (uso residencial) na Av. Calógeras em frente à Estação Ferroviária em 2014. Fonte: Próprio autor. 


\section{- A Escola Estadual de Primeiro Grau Álvaro Martins Neto, o "Batatinha"}

A escola foi desativada no início dos anos 2000, virou um centro de documentação da Secretaria Estadual de Educação - SED, hoje existe a possibilidade de ser transformada em museu da ferrovia, porém o projeto é ouvido apenas nas conversas entre os moradores da Rua Dr. Ferreira. Enquanto intervenção realizada, a escola também foi contemplada pelo projeto coral tudo de cor.

Hoje o "Batatinha" abriga um centro de documentação da secretaria de educação do Estado, sendo depósito de ficha de ex-alunos da rede estadual de ensino em Campo Grande, em um determinado momento houve boatos que abrigaria um pequeno museu, o que não ocorreu.

\section{- Clube Noroeste}

O Antigo clube Noroeste hoje abriga uma casa de shows que muitos ex-ferroviários frequentam, porém já não mantém o mesmo significado dos anos de funcionamento da ferrovia, seu estado de conservação é bom, porém alguns equipamentos tiveram seus usos convertidos. A quadra esportiva foi desativada e transformada em estacionamento, o campo de bocha foi demolido e em seu lugar foram construídas churrasqueiras de tijolos.

Estas intervenções foram realizadas pelo proprietário atual, dando fim ao espaço que era diariamente frequentado pelos ferroviários e seus filhos. Como o bem foi vendido antes do tombamento do Iphan, a Prefeitura juntamente com o Governo do Estado foi omissa, e nada pode ser feito.

\section{- Trilhos Urbanos e a Construção das Orlas}

As obras no complexo ferroviário referentes à esplanada e aos trilhos que cortam a cidade fazem parte do plano chamado de revitalização do Centro (Lei Complementar n. 161, de 20/07/2010) contido no programa Viva Campo Grande. Este projeto visa uma intervenção pública de dinamização da mobilidade urbana e acessibilidade, associadas a um processo de urbanização integrada; portanto, voltada para a provisão de serviços públicos de drenagem, acrescida de pavimentação e articulada às ações de revitalização econômica e urbanística dos 
principais centros articuladores das áreas de intervenção e de ampliação de serviços essenciais à população, tais como saúde e educação ${ }^{8}$.

O projeto foi elaborado pelo Planurb para uma área de 257 hectares (Zona Especial de Interesse Cultural do Centro - ZEIC/Centro), orçamento estimado em R\$ 270 milhões e com 92 ações previstas para serem desenvolvidas ao longo de 20 anos. Os objetivos são: proteger o patrimônio histórico e cultural, valorizar o espaço público e a economia da região, fomentar eventos e atividades de lazer, além de fortalecer a administração pública, nas áreas de fiscalização e monitoramento da ZEIC/Centro.

Este projeto visa também contribuir para o estabelecimento de novas economias urbanas, dotando as regiões e os bairros de infraestrutura urbana capaz de alavancar os investimentos públicos que estão sendo projetados para acidade e para a região, ampliando as possibilidades de acesso ao mercado de trabalho por uma parcela significativa da população. Esta proposta projeta um possível crescimento da região do complexo ferroviário, visando à valorização destes espaços. O projeto Viva Campo Grande teve como objetivo valorizar as regiões elencadas como necessitadas de melhoria de infraestrutura urbana, promovendo a valorização das áreas.Dentre estas áreas se encontra o entorno do complexo ferroviário, na região das orlas Morena e Ferroviária.

O projeto estabelece a criação de duas Orlas, uma ao longo do leito férreo desativado que corta o centro de Campo Grande (Orla Ferroviária) e outra que corta o corredor leste-oeste (Orla Morena) acompanhando o traçado férreo desativado e inclusive com vários pontos onde os trilhos já foram retirados. A concepção de orla é de justamente acompanharem o "leito" da linha férrea na parte urbana do município.

Entre os objetivos para a criação da Orla Ferroviária estão:

- Revitalizar área ociosa no centro da cidade, buscando a melhoria do seu padrão urbanístico, paisagístico, ambiental e social;

- Promover, através da iluminação pública, segurança e conforto para a circulação da população;

- Melhorar as condições de acessibilidade;

- Reconhecer as dinâmicas sociais, culturais e comerciais da área, bem como as transformações de seus espaços de convivência;

${ }^{8}$ Disponível em: http://www.capital.ms.gov.br/transparencia/canaisTexto?id_can=3707\&pg=2 , documento 03-SEGOV (RAA 2010) 
- Garantir a visibilidade da sinalização viária de sítios significativos e edificações consideradas patrimônio cultural;

- Promover a implantação de mobiliário urbano visando à melhoria de qualidade do espaço, mantendo uma relação de escala harmônica entre o equipamento e o espaço onde será implantado;

- Valorizar os espaços abertos, obras de arte e edificações, através da instalação de iluminação especial;

- Estimular o desenvolvimento de atividades noturnas;

- Estimular o desenvolvimento das atividades do comércio local (VIVA CAMPO GRANDE, 2009).

Para Orla Morena:

- Promover a integração das regiões leste e oeste;

- Revitalizar área abandonada;

- Melhorar as condições de mobilidade e acessibilidade;

- Reurbanizar e qualificar o entorno;

- Adequar e complementar o traçado de vias urbanas;

- Construir ciclovias e outros equipamentos públicos e de lazer;

- Aprimorar as condições de segurança e conforto da circulação (VIVA CAMPO GRANDE, 2009).

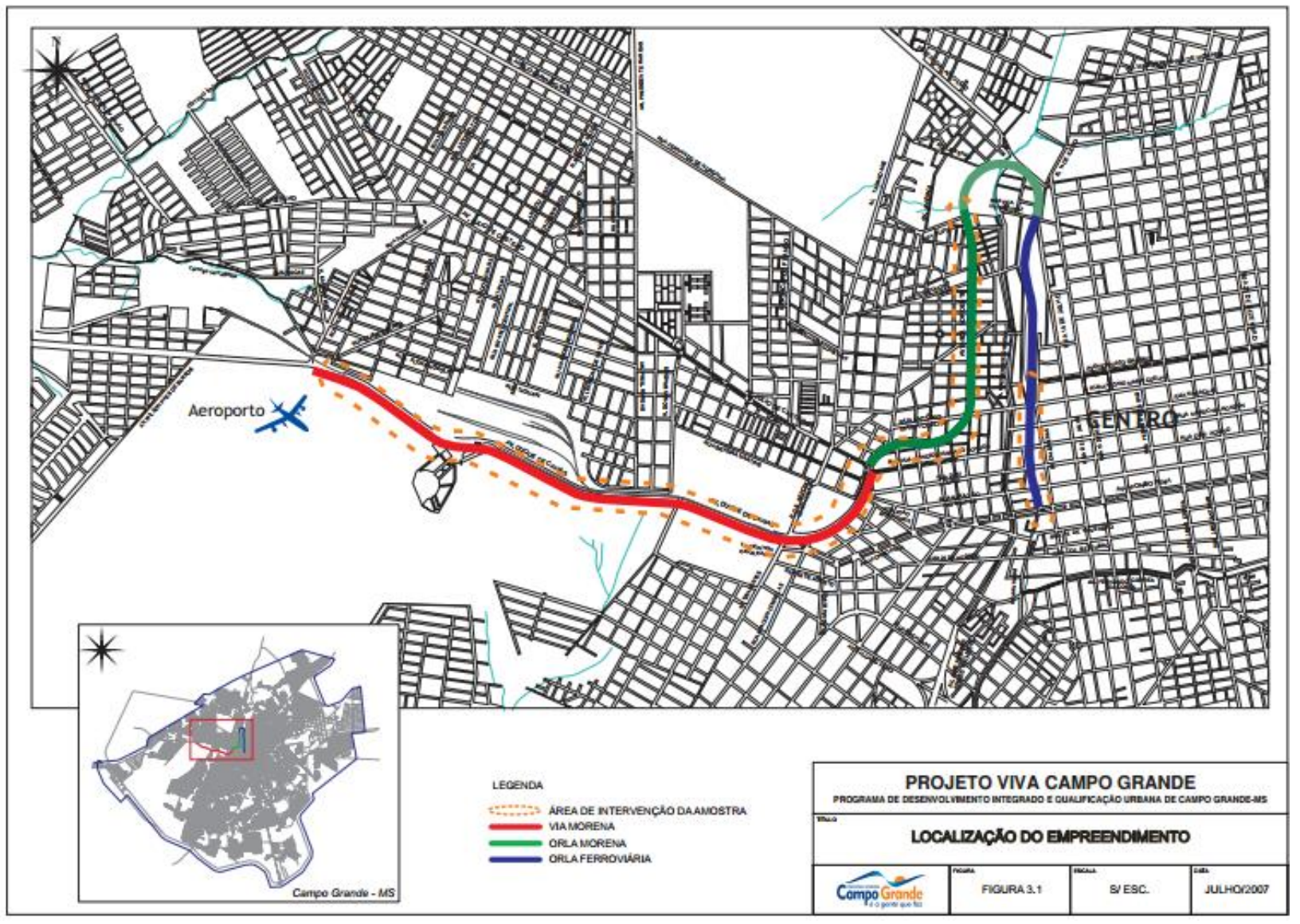

Figura 9. Mapa Orla Ferroviária e Orla Morena. Fonte: Projeto Viva Campo Grande (2007). 
O projeto Viva Campo Grande faz parte das atividades planejadas pela UPPE - Unidade de Programas e Projetos Especiais, da SEGOV - Secretaria Municipal de Governo e Relações Institucionais (SEGOV, RAA, 2010).

Termos como reurbanizar, revitalizar e qualificar estão contidos nos objetivos dos projetos das Orlas. Após a inserção da feira central no complexo ferroviário ficou claro o objetivo de valorização da região, observando atual quadro de conservação de alguns bem elucida muito bem a questão do que se quer/pretende valorizar no complexo ferroviário, esta explicito que o carro chefe do processo de valorização do complexo foi a feira central, e que apenas depois do tombamento realizado pelo Iphan que se deu um pouco mais de atenção ao verdadeiro significado do local, assim como também fica claro nos projeto a intencionalidade de transformar estes espaços em centros de circulação de pessoas aumentando assim a circulação financeira, se aproveitando do potencial histórico e cultural que a região traz.

O projeto da Orla Morena, conta com 2,3 km de extensão, ocupa o antigo traçado férreo na Av. Noroeste, foi dividido em duas fases, a primeira já entregue e a segunda em fase de conclusão, para sua construção foi realizada a retirada dos trilhos do centro da cidade.

A Orla morena (Fotos 35 e 36) é uma espécie de parque linear, vista pela população residente na região como um excelente destino dado ao espaço que estava em abandono com "mato tomando conta". Foi construída após o termino das obras do anel ferroviário terem sido concluídas na Capital, possui em sua extensão pista de caminhada, ciclovia, concha acústica e um grande espaço que abriga a feira do bairro Cabreúva, que possui mais de 50 anos de história. Do ponto de vista da memória ferroviária em alguns trechos foram deixados fragmentos de trilhos, que supostamente fazem alusão aos trens que por ali passavam diariamente, porém para um visitante de fora, sem a informação necessária simplesmente são trilhos lançados ao longo da obra, falta informação no local, e ate para a população mais nova da cidade são apenas elementos decorativos que lhe fogem conhecimento.

Nas Fotos 37 a 38 temos a última obra realizada até o momento no complexo ferroviário, a Orla Ferroviária. Ela abrange o traçado dos trilhos que saiam da estação ferroviária em direção ao centro da cidade, compreendendo as pontes que cortam as Ruas Antonio Maria Coelho e Maracajú, e as antigas passagens de nível nas Ruas Marechal Rondon, Barão do Rio Branco e Av. Afonso Pena. Esta obra visa criar um espaço de lazer, com pista de caminhada e ciclovia, 
além de carrinhos de lanche construídos em alusão a vagões de trem, conforme pode ser visto na foto 38 .
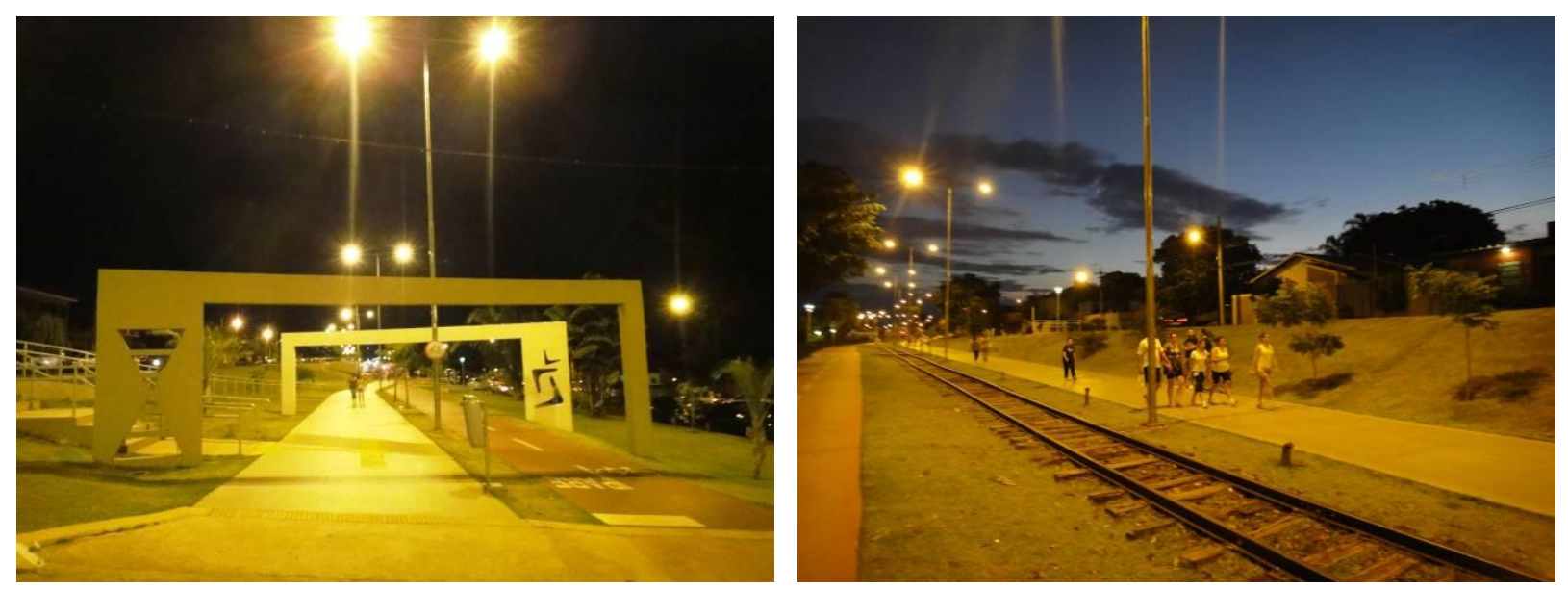

Fotos 35 e 36. Orla Morena2012 Fonte: Próprio autor.
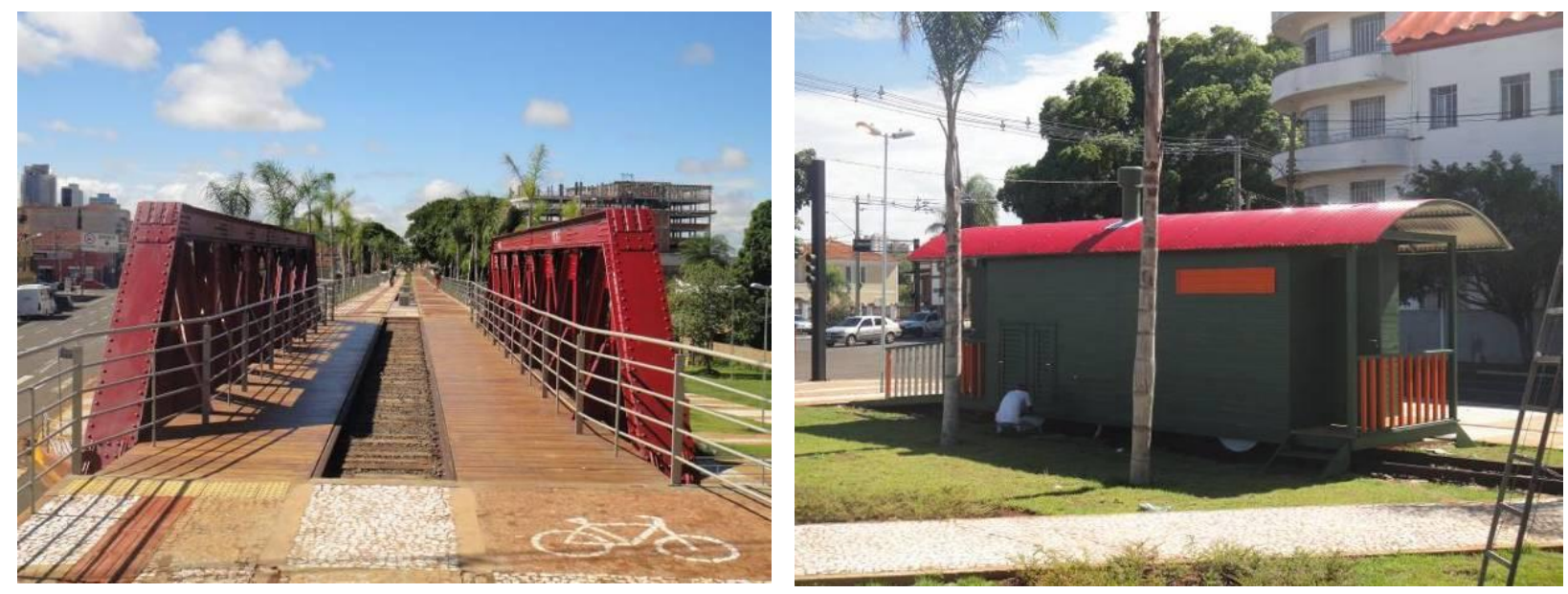

Fotos 37 e 38. Orla Ferroviária 2012 Fonte: Próprio autor. 
Tabela 1 - Síntese dos bens tombados da NOB em Campo Grande.

\begin{tabular}{|c|c|c|}
\hline Bem Tombado & Intervenção & Uso Atual \\
\hline Estação & $\begin{array}{l}\text { PAC cidades históricas } \\
2011 \text {. }\end{array}$ & Sem uso \\
\hline Armazém & $\begin{array}{l}\text { Pintura e reforma a em } \\
2011 .\end{array}$ & Eventos \\
\hline Oficinas & Nunca ocorreu & Algumas sem uso, outras moradia. \\
\hline Pátio de Manobras & $\begin{array}{l}\text { Inserção em } 2006 \text { obras } \\
\text { da prefeitura }\end{array}$ & Feira Central \\
\hline Rotunda & Nunca ocorreu & Abandonada \\
\hline Escritório dos Engenheiros & $\begin{array}{l}\text { Pintura e modernização } \\
\text { interna em } 2009\end{array}$ & Superintendência do Iphan \\
\hline Casas Rua Dr. Ferreira & $\begin{array}{l}97-98 \text { rearranjo dos } \\
\text { paralelepípedos; Projeto } \\
\text { tudo de cor coral - } 2011\end{array}$ & Residencial \\
\hline Casas da Rua dos Ferroviários & Nunca ocorreu & Residencial \\
\hline Casas dos funcionários Intermediários & Nunca ocorreu & Residencial/2 casas convertidas em restaurantes \\
\hline Casas dos funcionários Graduados & $\begin{array}{l}\text { reforma de duas casas } \\
\text { em } 2009\end{array}$ & $\begin{array}{l}\text { Residencial, Gabinete da Prefeitura e Instituto } \\
\text { Histórico e Geográfico do MS }\end{array}$ \\
\hline
\end{tabular}

Esta Tabela representa de forma sintetizada as intervenções e o atual uso dos bens da ferrovia tombados em Campo Grande. É interessante observar que os bens com significado amarrado a memória do trabalho na ferrovia não receberam intervenções buscando sua reinserção na atual urbanidade da cidade.

Este aspecto traz uma reflexão sobre o processo de revitalização do complexo ferroviário, que apresentou intervenções pontuais, contradizendo o entendimento explicito no tombamento federal, onde o conjunto dos bens da ferrovia é entendido como um importante e relevante complexo ferroviário no município.

Como valorizar uma memória ferroviária deixando de lado os aspectos que de fato permeavam a vida dos moradores da cidade e dos trabalhadores da ferrovia? $\mathrm{O}$ fato de estes bens estarem em segundo plano no processo de revitalização da prefeitura aponta que o que ocorreu em Campo Grande (e ainda ocorre) foi um processo de valorização da região, dado por um projeto urbanístico que se utilizou do peso e apelo histórico da NOB em Campo Grande, para promover os novos "points" na cidade, trazendo consigo o peso da especulação imobiliária, valorizando financeiramente a região.

Elementos como a estação, o armazém e as casas da Rua Dr. Ferreira, fazem fronteira direta com a feira central inserida em meio ao complexo ferroviário, sendo a "cereja no bolo" da intervenção municipal, onde os bens citados se tornam coadjuvantes no processo de requalificação da região. 
Estes bens receberam sim algumas intervenções, no caso da Dr. Ferreira o projeto de tudo de cor, realizou a pintura das fachadas das casas, uma melhoria estética apenas, sendo que muitas casas precisam de melhorias em suas estruturas e muitos dos moradores não dispõem de recursos para tal. No caso da estação e armazém, percebe-se que foi apenas mantido a integridade dos bens e mesmo com usos esporádicos (eventos e feiras no armazém), de fato estes itens não foram reinseridos na dinâmica urbana atual de Campo Grande, o não uso da estação afirma categoricamente este apontamento, deixando ainda mais explícito que a memória ferroviária foi utilizada apenas como discurso, pois um símbolo tão forte como a Estação esta parada no tempo, sem uma utilidade que extrapole seu valor histórico e simbólico se tornando apenas "objeto no caminho da feira, o que reforça a ideia de o espaço como valor de troca e a pouca importância atribuída, nesta lógica, à memória urbana, ou seja, a lógica capitalista pressionando e transformando a cidade em mercadoria, sobrepondo-a ao valor de troca.

Lefebvre (1991) escreve que a cidade é uma obra, e esta característica contrasta com a orientação irreversível na direção do dinheiro, na direção do comércio, na direção das trocas, na direção dos produtos. Para ele a obra é valor de uso e o produto é valor de troca. $\mathrm{O}$ uso principal da cidade, por parte das pessoas segundo o autor se dá pela festa, ou simplesmente pela apropriação do espaço público de forma que ocorra a troca simbólica de experiências, a reprodução do cotidiano.

Nesse caso o patrimônio ferroviário de Campo Grande não recebeu um apelo voltado ao seu significado enquanto símbolo de memória coletiva; foi usado para agregar valor econômico as intervenções urbanas municipais, sendo utilizado como ancora para criação de um novo urbano, constituído pela requalificação da região onde antes era conhecida apenas pela presença da ferrovia.

Matos (1995) escreve que no espetáculo da multidão o indivíduo se perde e, para ele, a cidade se torna ora passagem ora vitrine o que remete ao lugar de passagem sobrepondo o lugar de memória transformando o complexo ferroviário em um local estático e não inserido na nova dinâmica urbana de forma que represente sua importância e ganhe uma nova função nesse contexto.

Com isto, entende-se que a revitalização do complexo dissolve a memória ferroviária como conjunto, fragmentando uma percepção de processo histórico, não traz um apelo a memória ferroviária na cidade, e sim uma valorização no entorno do elemento que nada remete a ferrovia, 
a feira central. E que mesmo após o tombamento realizado pelo Iphan, o projeto em curso da prefeitura se concretizou e coube ao órgão federal apenas coibir e regulamentar futuras ações municipais.

\subsection{A Memória dos Ferroviários}

Através das entrevistas realizadas com ex-funcionários da ferrovia Noroeste do Brasil em Campo Grande, foi possível perceber que além da memória amarrada ao espaço físico, muito do que eles se recordam de forma saudosa, diz respeito às relações propiciadas pela ferrovia, ou melhor, pelo trabalho e convívio na ferrovia - o modo de vida, os fazeres e as relações construídas no complexo ferroviário.

Muito mais do que o ato de bater o cartão na entrada e saída do trabalho, a ferrovia propiciava um ambiente de plena interação e não apenas pelo trabalho em si, mas pela forma de relação entre seus funcionários e respectivos familiares. Entre cada futebol de final de semana, torneio de bilhar e bocha, churrascos dançantes no clube Noroeste, festas comemorativas, o trem do natal que trazia presentes para os filhos da ferrovia, desde o fornecimento de água potável ao encontro de fim de tarde nas calçadas das casas ferroviárias tudo que se tinha era um modo especifico de reprodução do cotidiano, da realização de vida daquelas pessoas sendo fortemente permeada pela ferrovia.

As ferrovias de um modo geral inseriram a dinâmica do trabalho assalariado atraindo trabalhadores de diversas locais em busca de melhores condições de vida, como escreve Costa (1975, p. 160): “As vias férreas tenham se tornado o embrião do trabalho assalariado no Brasil e em São Paulo, atraindo e concentrando tanto mão de obra nacional quanto a estrangeira”.

A autora escreve que esta mão de obra é o início de um proletariado precoce e embrionário, dentro de uma ordem escravista, coexistindo contraditoriamente com a velha ordem, cuja superação histórica acelera.

Isto aponta a formação de uma classe trabalhadora específica, que ainda não discutia melhorias de condições de trabalho, porém já era vista como uma categoria, e prontamente já reconhecida como operários da ferrovia, os ferroviários.

Sobre a memória dos ferroviários dois fatores merecem destaque: O primeiro diz respeito a memória do trabalho, do desejo em trabalhar na ferrovia até a ascensão social que ela propiciava a seus funcionários. O trabalho na NOB/RFFSA, mesmo sendo um trabalho difícil era visto 
como uma boa opção profissional, possuindo um significado positivo para seus funcionários que, através das entrevistas realizadas com os ex-ferroviários foi possível perceber que todos falam com orgulho de terem trabalhado na rede.

O segundo fator importante é a construção de uma identidade especifica à ferrovia, uma identidade de classe, repetida pelos entrevistados ao dizerem sobre o "orgulho de ser ferroviário", independente do nível de seu cargo na escala do trabalho na ferrovia, todos fizeram esta afirmação.

A partir das entrevistas realizadas com os ex-ferroviários, dois pontos se fazem importantes, a do trabalho na ferrovia e a do fim trabalho na ferrovia, dois momentos distintos na vida destas pessoas que relatam uma memória coletiva criada a partir das relações trabalho e também uma memória constituída pela lembrança pura (BOSI, 2005), que relata muito bem a questão do fim do trabalho na ferrovia, que reaparece através da lembrança de momentos únicos vividos na teia de relações construídas no dia a dia de trabalho, lazer e vivência.

A memória possui importante papel na transmissão dos valores culturais, mantendo vivas as tradições, costumes e crenças, sendo assim alguns conceitos são importantes para análise da memória ferroviária em Campo Grande.

De acordo com Abreu (2011), a memória tanto individual quanto coletiva, se estrutura quando consegue - se ancorar simultaneamente no tempo e no espaço, ou seja, a memória urbana constitui-se de um apanhado de acontecimentos e realizações, reproduzidos ao longo dos anos, de acordo com a singularidade dos lugares. O que cabe a memória do trabalho na ferrovia, construída sobre as relações diárias nos barracões, escritórios e demais dependências de forma única e lembrada pelos ex-ferroviários em seus depoimentos, evidenciando o sentimento de orgulho em relação ao trabalho e a influencia que a ferrovia teve em suas vidas.

Ainda sobre a influência do espaço físico sobre a memória, o conceito de lugar de memória surge a partir de discussão desenvolvida na França, cujo historiador Pierre Nora foi o precursor. Um lugar de memória existe a partir do desejo dos homens e/ou com o passar do teтро; refere-se e necessita tanto de um suporte material quanto de um abstrato, ou simbólico; é aquilo que restou e se perpetua de um outro tempo; é um registro e também aquilo que o transcende, pois seu sentido simbólico está inscrito no próprio registro(FREIRE et al., 2012).

Os Pátios Ferroviários, como lugares de memória no contexto dos complexos Ferroviários possuem uma memória estratificada representativa de cada uma de suas épocas. 
Cronologicamente, uma de suas leituras possíveis refere-se à ordem de aparecimento dos elementos estruturais e infra-estruturais necessários ao funcionamento de um Pátio. E a cada uma dessas fases históricas correspondem também funções específicas que se complexificam conjuntamente ao processo de desenvolvimento das cidades (FREIRE et al., 2012).

Segundo Nora (1981):

“... a sociedade necessita desses lugares porque não possui mais meios de memória no atual momento histórico-cultural, tendo em vista que a evolução urbana a descaracteriza à medida que destrói seus lugares".

Este ponto é fortemente evidenciado no processo de intervenção da ferrovia em Campo Grande, pois o complexo ferroviário foi inserido num novo contexto urbano, sendo usado apenas como apelo, onde o carro chefe do processo foi um elemento estranho a historia férrea do município, que descaracterizou a região e agora cria uma nova memória no local.

Para Delgado (2006), a memória não apresenta definição conceitual: refere-se à construção de identidades e ao fortalecimento de consciências individuais e coletivas; ainda, a vivência cotidiana conforma a memória durante a existência e ordena as significações das experiências; reflete o passado no ato da verbalização e do estudo no tempo presente; reencontra e reconhece espaços e lugares; necessita de um suporte para vir à tona através da recordação, seja este suporte material ou subjetivo (FREIRE et al., 2012).

Pressupõe-se então que conceito de "lugar" está diretamente implicado com o de memória, podendo ser entendido como o resultado de práticas sociais distintas e do sentimento de pertença que lhe é inerente,sendo uma representação à medida que é real e o ultrapassa, ganhando diversos níveis de compreensão e afetividade, ao passo que é compreendido pelos indivíduos no decorrer do percurso histórico, podendo ser potencializado ou diminuído, conforme a existência ou não de ações para a sua preservação e promoção (FREIRE et al., 2012).

Através dos relatos orais dos ex-funcionários pode-se compreender não somente aspectos do funcionamento de um Pátio Ferroviário em determinados momentos de sua evolução, mas também perceber como a vida cotidiana destes trabalhadores e suas histórias de vida se confundem com a própria história da ferrovia NOB/RFFSA. 
Neste aspecto, a história oral insere no momento em que incide sobre a memória do lugar. Por serem construídas na coletividade vivida pelo sujeito, as memórias então narradas dotam de sentido a vida social (FREIRE et al., 2012).

A História Oral faz a intermediação entre o fato específico em menor escala e a história geral, situando e referenciando o cotidiano em um universo mais amplo, permitindo a análise das vivências em relação às estruturas da sociedade. Entende-se então que a memória dos ferroviários foi socialmente construída a partir das relações de trabalho na ferrovia e do próprio trabalho, sua rigidez e características específicas.

Sendo assim, a partir das entrevistas realizadas com os ex-ferroviários foi possível compreender que a ferrovia era um ambiente disputado e que mesmo com as dificuldades do trabalho era objeto de desejo, pois era a garantia de emprego estável e com bons benefícios. Uma vez dentro da ferrovia NOB e posteriormente RFFSA, os funcionários se empenhavam para passar nos concursos internos, visando melhoria salarial e profissional.

Valdoveno Marques, que foi da chefia de recursos humanos na NOB/REFFSA em Mato Grosso do Sul, conta que existiam espécies de cursinhos preparatórios para alguns concursos internos, e que as vagas eram muito disputadas, "no cursinho não podia faltar, quem faltava perdia a vaga e ficava difícil passar”.

"O sujeito entrava e tinha oportunidade de crescer lá dentro, tinha muita oportunidade, pra funcionário do trecho e funcionário do escritório”, comenta o senhor Nelson, que trabalhava na fiscalização das linhas (Entrevista concedida ao autor, em Janeiro de 2013).

Ao longo das entrevistas é surpreendente como o trabalho na ferrovia é lembrado apenas de forma positiva, mesmo em se tratando de um trabalho pesado em determinadas funções, isso traz uma reflexão sobre o passado sendo percebido a partir do presente, ou seja as condições de hoje enaltecem o passado, o glorificando, independente das condições de trabalho da época, ou dificuldades existentes na execução do trabalho.

A ferrovia representava estabilidade, "era um emprego daqueles que você saia velho, aposentado" relata Pedro Alves ex-chefe de estação, ela oferecia benefícios e traçava metas para seus funcionários, que tinham a possibilidade de construir uma carreira, propiciava ascensão social. 
"Eu entrei muito novo na rede, e fui subindo de cargo, trabalhei no telegrafo, fiz muita coisa ate virar chefe de estação, a empresa valorizava quem se esforçava, era só o cara ser bom de serviço” comenta Pedro Alves (Entrevista concedida ao autor, em Janeiro de 2013).

Olhando o trabalho na ferrovia em um contexto geral, é nítido que a empresa tinha um respaldo principalmente pelas possibilidades internas, porém é interessante e de extrema importante a identidade de classe que foi criada pelo trabalho que propiciou o pertencimento de seus funcionários e orgulho em se afirmarem como ferroviários. "Eu tenho orgulho de ser ferroviário, de ter feito parte da história da ferrovia”, afirmação esta repetida em todas as entrevistas realizadas e percebida na apenas nas palavras ditas, mas também na emoção e no brilho dos olhos dos aposentados.

“... a gente tinha tanta força que vinha político atrás de voto, ferroviário era unido, se reconhecia e tinha reconhecimento" comenta Roberto Teixeira, ex-maquinista e hoje um dos diretores do sindicato dos ferroviários (Entrevista concedida ao autor, em Janeiro de 2013).

Identidade esta que se desestabilizou com o processo de privatização, onde muitos perderam seus empregos e se viram a beira de desespero. Este momento é muito importante na história da ferrovia em Campo Grande, pois, nessa época não se sabia ao certo o futuro da ferrovia e as conversas sobre o fim da companhia eram comuns entre os funcionários e seus familiares.

Pedro Alves comenta que em 1993, ano que se aposentou, foi induzido a se aposentar por um dos seus chefes, que revelou a ele que alguns cargos seriam extintos e consequentemente muita gente iria ser mandada embora.

"Eu não queria sair, já tinha tempo de serviço, mas gostava de trabalhar na Rede, fiquei com medo, tinha filhos e família que precisavam de mim, só sabia ser ferroviário ai aposentei e três anos depois veio a privatização e o fim da rede" (Entrevista concedida ao autor, em Janeiro de 2013).

E de fato com a privatização em 1996, muitos ferroviários foram demitidos, muitos não conseguindo se recolocar no mercado de trabalho, porque como Pedro Alves disse, "eu só sabia ser ferroviário”, o trabalho específico, designado por alguns, só existia na ferrovia. 
Valdoveno Marques relata que funcionários demitidos batiam a sua porta no meio da noite desesperados por não saber o que fazer de suas vidas.

"Foi uma época difícil, companheiros de anos de trabalho que se perderam no alcoolismo, não conseguiram se reafirmar no mercado de trabalho, tiveram que sair das casas cedidas pela ferrovia, com filhos pequenos, esposa... a gente se sentia culpado, mas ordem vinha de cima" ( Entrevista concedida ao autor, em Janeiro de 2013.

Sobre a privatização e demissões em massa, Roberto Teixeira, afirma que o sindicato sempre teve um papel de luta em prol dos ferroviários, e que no início da década de 90 as políticas de privatização do governo brasileiro contribuíram para o desmonte da ferrovia, e que os interesses da privatização na realidade contemplavam os interesses da iniciativa privada, que favoreciam o transporte rodoviário. Ele relata esta época com um período muito triste, onde vários companheiros de trabalho foram demitidos da ferrovia com a especificidade do trabalho único que era realizado nela, e que justamente por isso muitos não conseguiram se fixar no mercado de trabalho. Como o próprio Roberto afirma: ..."ferrovia é ferrovia, é um trabalho único”. No período que antecedeu a privatização, já se ouvia nos bastidores da empresa que isso poderia acontecer, o que causou certo receio entre os funcionários, principalmente os mais antigos, que ficaram inseguros sobre seu futuro.

Mas nem só de memórias tristes e de tempos difíceis vive o ex-ferroviário, todos se recordam de forma saudosa dos tempos de trabalho e do que a ferrovia fez em suas vidas.

José Carlos Rocelli, o último funcionário a sair da RRFFSA, hoje transferido para o DNIT por ser funcionário público federal e ter prestado serviço até a transferência de tutela dos bens da ferrovia para tal órgão, recorda os jogos de futebol entre os funcionários, os almoços de domingo, o trem de final de ano que trazia brinquedos e cestas de natal aos funcionários, "ficava parado a semana toda de natal na esplanada, a gente ia lá e retirava os brinquedos e o panetone para as crianças”.

"Tinha coisa muita boa na ferrovia, por futebol o pessoal trocava até escala! E no natal a criançada ficava doida com o vagão lotado de brinquedo e panetone, só não gostavam da liturina do dentista!!!"comenta Rocelli (Entrevista concedida ao autor, em Janeiro de 2013). 
Estes relatos evidenciam dois importantes seguimentos da memória, primeiro a memória do trabalho, que diz respeito as lembranças sobre o exercício da função e as relações propiciadas por ele, e segundo a memória que vem a tona pelo fim do trabalho na ferrovia.

A memória do trabalho é positiva, pois ela traz a questão da identidade de classe, das relações, seja no trabalho ou no lazer, lembradas sempre com orgulho e saudade.

A memória do fim do trabalho é negativa, pois traz o fechamento de um período, de possibilidades e de ascensão profissional, é fortemente marcada pela privatização da ferrovia e o consequente desemprego em massa.

Esta duplicidade de significados nos leva a discussão sobre o processo de revitalização realizado no complexo ferroviário de Campo Grande, qual o objetivo destas intervenções e principalmente como ela é entendida em um contexto muito mais amplo entre o significado da ferrovia para a cidade e a memória dos ex-ferroviários.

\subsection{As intervenções na Perspectiva de Quem?}

Como parte importante desta pesquisa, deve-se buscar o entendimento sobre o patrimônio e a sua relação com as transformações urbanas na atualidade, do ponto de vista dos moradores da cidade e dos ex-ferroviários.

Entendendo que a paisagem urbana de uma cidade é carregada de traços que pertenceram a vários períodos pelos quais desenvolveu sua história. $\mathrm{O}$ desenho urbano, as ruas, as praças, as casas, os postes, tudo faz parte de um movimento de materialização das mudanças sócio-políticas do grupo que ocupa aquele local. "A cada decisão tomada, a cada mudança na economia, a cada tendência social, a paisagem vai ganhando novos elementos que, ou substituem alguns antigos, ou vem pra somar com os já existentes" (SOUZA; SOARES, op.cit., p. 65). Entretanto, deve-se levar em consideração se as mudanças no complexo ferroviário de Campo Grande visam apenas revalorizar um espaço através de reformas e "maquiagens", ou visam resgatar e respeitar o passado de um conjunto tão importante para o desenvolvimento da cidade, tendo aqui dois caminhos que podem ou não ser opostos: o da espetacularização do passado e a da inserção desses lugares de memória na dinâmica urbana atual.

Choay (2001, p. 222) afirma que: 
[...] tendo se tornado patrimônios históricos de pleno direito, os centros e os bairros históricos antigos oferecem atualmente uma imagem privilegiada, sintética e de certa forma magnificada, das dificuldades e contradições com as quais se confrontam a valorização do patrimônio arquitetônico em geral, e em especial sua reutilização ou, em outras palavras, sua integração com a vida contemporânea.

Dessa forma, entende-se que a valorização do patrimônio pode ser uma tentativa de reinvenção da cidade, produzindo valor a partir da espetacularização do passado, se enquadrando dentro de uma nova perspectiva de reprodução do capital. Jeudy (2005) escreve que o valor patrimonial faz o papel de "marca", cria-se uma espécie de garantia de autenticidade, um selo que permite a valorização, que garante ao patrimônio um reconhecimento institucional.

A perspectiva da análise da produção do urbano a partir da reflexão de Lefebvre (2006) aponta para a crise das cidades, entendendo sua trajetória, tendo como inicio o processo de industrialização e a urbanização como reflexo desta e a restituição da centralidade nos tempos atuais, ou seja, a reinvenção sobre o centro antigo por meio de práticas de revalorização, fazendo o núcleo urbano sobreviver graças a um duplo papel: o de lugar de consumo e o consumo do lugar (2006, p. 20).

A ação de revitalização de um centro histórico deve acompanhar o crescimento urbano proporcionando novos usos e inserindo estes bens na dinâmica do tecido urbano atual, pois o espaço urbano está em processo de constante transformação, e os espaços onde se encontram estes bens patrimoniais hoje não são os mesmos da época da sua construção, e nem mesmo a sociedade ali presente.

Para Santos (1992, p. 49):

"Alguns elementos cedem lugar, completa ou parcialmente, a outros da mesma classe, porém mais modernos; outros elementos resistem à modernização; em muitos casos, elementos de diferentes períodos coexistem. Alguns elementos podem desaparecer completamente sem sucessor e elementos novos podem se estabelecer".

O complexo ferroviário de Campo Grande vem sofrendo intervenções desde a década de 90, uma série de manobras políticas e especulações marcam este período. Desde a privatização muito se ouviu a respeito dos bens edificados da ferrovia, o que seria feito, qual o destino da 
ferrovia na cidade. O imaginário dos ferroviários e residentes do entorno passou a ser ocupado por uma serie e dúvidas e questionamentos.

O maior medo até então é de que tudo fosse colocado a baixo, para o surgimento de algum empreendimento imobiliário e a questão do despejo também passava pela cabeça destas pessoas, até construção de um shopping virou boato nas rodas de conversa.

De certa forma o desejo era de permanência da ferrovia, o que não foi possível devido a depreciação que o transporte ferroviário tem no Brasil devido a falta de interesse do governo em investir nas melhorias necessárias para que se tornasse concreto o retorno do "trem".

Estas dúvidas e incertezas permearam durante um bom tempo os moradores da região, tendo ápice em 1996 quando começou a operação de retirada dos trilhos do centro da cidade, episódio que feriu gravemente a história não apenas da ferrovia e seus ex-trabalhadores, mas também a história de Campo Grande.

Este episódio foi o divisor de águas, pois colocou em cheque as políticas de preservação na cidade, sendo a retirada dos trilhos um ato arbitrário, sem consulta prévia da população, feito do dia para noite, demonstrando um grande descaso com a história local e o sentimento das pessoas.

Para substituir os trilhos foi proposto o projeto de uma grande orla que pouco remete a historia da ferrovia na cidade, trouxe melhorias para os moradores que habitavam o entorno dos trilhos, mas junto com as melhorias trouxe a especulação imobiliária, a valorização foi de cerca de $40 \%{ }^{9}$ dos imóveis localizados em frente ao trecho da orla no Bairro Planalto.

Buscando entender a visão dos moradores da cidade sobre as intervenções nos bens da ferrovia na cidade foram realizadas além das entrevistas com ex-ferroviários, a aplicação de questionários com frequentadores do complexo ferroviário, principalmente na feira central.

O questionário aplicado a frequentadores do complexo ferroviário foi elaborado no método quantitativo, com suas questões formuladas de maneira fechada, com respostas fixas afirmativas e negativas, com exceção aos complementos das questões 1 e 9.

Foi formulado com 12 questões, sendo aplicado para 50 pessoas, 45 são residentes de Campo Grande e 5 pessoas de outras cidades, foi estruturado pelo método quantitativo. O

${ }^{9}$ De acordo com site de noticias Campo Grande News, noticiado em maio de 2012 consultado em dezembro de 2013. Disponível em http://www.campograndenews.com.br/cidades/capital/point-da-vida-saudavel-orla-morenavaloriza-imoveis-no-seu-entorno. 
número de entrevistados foi consequência da dificuldade na aceitação das pessoas abordadas em responder o questionário.

Tabela 2. Questionário aplicado em trabalho de campo.

\begin{tabular}{|c|c|}
\hline 1 & Você acha que a ferrovia foi importante para a cidade? S ( ) N( ) Porque? \\
\hline 2 & $\begin{array}{l}\text { Você sabia que a ferrovia é tombada, que ela é um patrimônio cultural da cidade, do Estado e do país? S ( ) } \\
\text { N ( ) }\end{array}$ \\
\hline 3 & Você acha que isso é importante? S( ) N( ) \\
\hline 4 & Sendo a ferrovia patrimônio, você concorda com a retirada dos trilhos do centro da cidade? S( ) N( ) \\
\hline 5 & $\begin{array}{l}\text { Acha as obras na região da ferrovia (feira central, orla morena e orla ferroviária) importantes para a } \\
\text { preservação da memória ferroviária na cidade? } \mathrm{S}(\mathrm{N}(\mathrm{)})\end{array}$ \\
\hline 6 & Acha que estes espaços estão sendo bem utilizados? $\mathrm{S}(\mathrm{)}) \mathrm{N}($ ) \\
\hline 7 & Acredita que trouxe melhorias para Campo Grande? $\mathrm{S}($ ) $\mathrm{N}(\mathrm{)}$ \\
\hline 8 & $\begin{array}{l}\text { Percebe traços da ferrovia no local S( ) N( ) Acha que o espaço está descaracterizado? } \\
\mathrm{S}(\text { ( ) N ( ) }\end{array}$ \\
\hline 9 & Acha que estas obras transparecem a importância da ferrovia para Campo Grande? S( ) N( ) \\
\hline 10 & $\begin{array}{l}\text { Acha que outros tipos de uso para o complexo ferroviário seriam mais interessantes que os atuais? S( ) N( ) } \\
\text { Alguma Sugestão? }\end{array}$ \\
\hline 11 & Já fez uso do transporte Ferroviário em Campo Grande? S ( ) N ( ) \\
\hline 12 & É a favor da volta do transporte ferroviário? \\
\hline
\end{tabular}

Dos entrevistados, 25 (50\%) estão na faixa etária de 16 a 30 anos (portanto não são exferroviários), 8 pessoas na faixa de 30 a 50 anos e 17 pessoas à cima dos 50 anos. A escolaridade dos entrevistados correspondendo a $46 \%$ possui superior completo, $10 \%$ superior incompleto, $22 \%$ médio completo, $8 \%$ médio incompleto, $10 \%$ fundamental completo e $4 \%$ fundamental incompleto constituindo um perfil de maioria jovem e com ensino superior completo. 


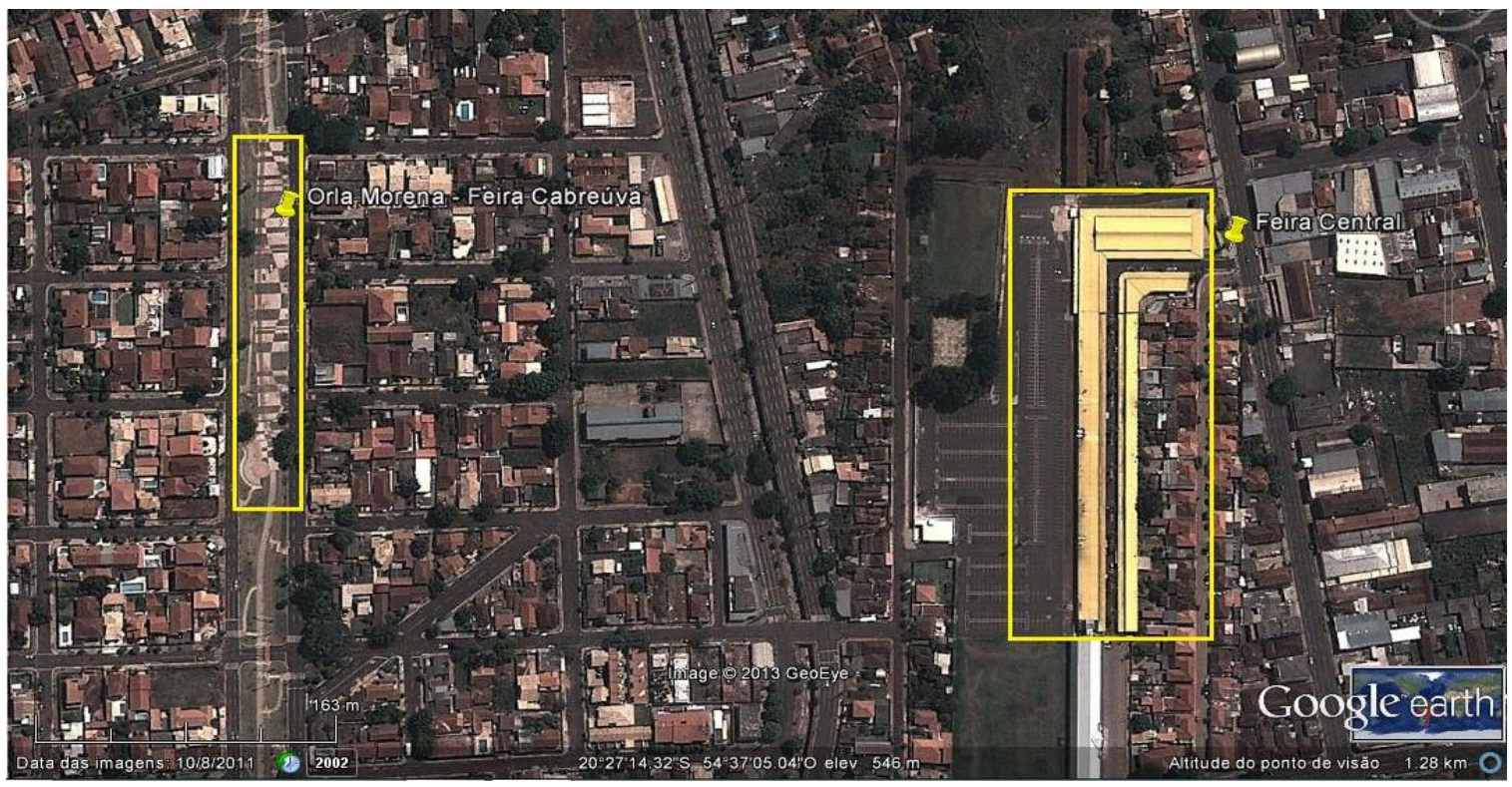

Figura 10. Localização dos pontos de coleta de dados, Feira do bairro Cabreúva na Orla Morena e Feira Central antiga esplanada ferroviária.

Tabela 3 - tabulação das respostas das questões do trabalho de campo.

\begin{tabular}{|c|c|c|c|c|}
\hline Questões & Sim & Não & Sim (\%) & Não (\%) \\
\hline 1 & 50 & - & $100 \%$ & - \\
\hline 2 & 35 & 15 & $70 \%$ & $30 \%$ \\
\hline 3 & 43 & 7 & $86 \%$ & $14 \%$ \\
\hline 4 & 19 & 31 & $38 \%$ & $62 \%$ \\
\hline 5 & 34 & 16 & $68 \%$ & $32 \%$ \\
\hline 6 & 35 & 15 & $70 \%$ & $30 \%$ \\
\hline 7 & 42 & 8 & $84 \%$ & $16 \%$ \\
\hline 8 & 31 & 19 & $62 \%$ & $38 \%$ \\
\hline 9 & 37 & 13 & $74 \%$ & $26 \%$ \\
\hline 10 & 15 & 35 & $30 \%$ & $70 \%$ \\
\hline 11 & 34 & 16 & $68 \%$ & $32 \%$ \\
\hline 12 & 32 & 18 & $64 \%$ & $36 \%$ \\
\hline
\end{tabular}

Com a primeira questão, conclui-se que os entrevistados reconhecem a ferrovia como responsável pelo desenvolvimento da cidade. Como complemento da mesma questão foi perguntado o porquê e a resposta mais frequente foi que a ferrovia trouxe desenvolvimento para cidade, para o Estado e que durante muitos anos foi o único meio de comunicação territorial com outros estados do Brasil e até mesmo Paraguai e Bolívia. 
A segunda questão buscou conhecimento por parte dos entrevistados sobre o tombamento da ferrovia pelo município, Estado e Governo Federal. Conclui-se que a maior parte dos entrevistados tem este conhecimento.

A terceira questão, em complemento a segunda, remete a importância do tombamento, na percepção dos entrevistados, a maioria se mostrou favorável a ele e pode-se concluir com isto que a ferrovia tem sim um reconhecimento enquanto patrimônio da cidade.

$\mathrm{Na}$ quarta pergunta, conclui-se que, a maioria dos entrevistados se mostrou contra a retirada dos trilhos, alegaram que com isso parte da história de Campo Grande foi prejudicada. Os trilhos definiram o traçado de ruas importantes na cidade, portanto fizeram parte da gênese da formação da malha urbana da região central. Muitos entrevistados ainda comentaram que não atrapalhavam em nada na circulação de pedestres e veículos, visto que os trilhos já não estavam em funcionamento.

A quinta questão, já entra nos campos da preservação, memória e ações do poder público. A maior parte dos entrevistados respondeu que as obras realizadas no complexo ferroviário são importantes para a preservação da memória ferroviária. É interessante destacar que mesmo algumas obras não mantendo elementos que façam menção a ferrovia, elas são consideradas importantes para a memória ferroviária na percepção dos entrevistados.

$\mathrm{Na}$ sexta pergunta, os entrevistados foram questionados se estes espaços estão sendo bem utilizados, $70 \%$ responderam que sim, e 30\% responderam que não.

Conclui-se na sétima questão que, na visão dos entrevistados, as obras de revitalização trouxeram melhorias para Campo Grande.

Aqui é importante evidenciar que os entrevistados julgam os espaços como bem utilizados, pois trouxeram melhorias e movimentação a região, porém ocasionados por elementos que não estão diretamente ligados a Memória ferroviária, caso da feira central, e elementos que não tem uma relação direta com a ferrovia, caso da orla morena, que descaracterizou o traçado férreo na cidade.

Estes equipamentos urbanos foram responsáveis pela "volta" da população a frequentar a região, frutos do processo de intervenção municipal sobre o patrimônio ferroviário, sendo que na realidade esta requalificação urbana se deu através do apelo do patrimônio ali existente sem realmente ser uma intervenção visando à memória ferroviária. 
$\mathrm{Na}$ questão oito, a maioria dos entrevistados consideram os espaços descaracterizados, o que é interessante, pois mesmo com isso as pessoas veem às obras no complexo ferroviário como importantes para a preservação da memória.

Ainda sobre o uso do espaço e memória, foi perguntado na questão nove se os entrevistados acham que estas obras de revitalização transparecem a importância da ferrovia para Campo Grande, 30\% respondeu sim e 70\% responderam não.

Com isso, conclui-se até aqui que os entrevistados são favoráveis a possíveis melhorias para Campo Grande mesmo que estas transformem os espaços e não façam menção a seus significados originais, sendo possível pensar na condição do patrimônio enquanto bem transformado de acordo com as "necessidades" de modernização do urbano e não sendo inserido nesta dinâmica enquanto lugar de memória.

A questão dez, remete a satisfação em relação às obras no complexo ferroviário, se os entrevistados estão satisfeitos e até mesmo se concordam com as ações realizadas, então foi perguntando se outros tipos e usos seriam mais interessantes do que os atuais no complexo ferroviário, $68 \%$ responderam que sim e $32 \%$ se demonstraram satisfeitos. Complementando esta questão foi perguntado se teriam alguma sugestão dentre as respostas mais comuns, estão que seria interessante a construção de um parque, museu e um memorial para a ferrovia, além de vários entrevistados terem sugerido um complexo turístico educacional integrado, com a possibilidade de translado de trem entre pontos específicos da cidade.

As questões onze e doze têm como objetivo o numero total de entrevistados que já fizeram uso do transporte ferroviário em Campo Grande e quantos são a favor da volta do transporte ferroviário no Brasil. Dos entrevistados $94 \%$ são a favor da volta dos trens de transporte no Brasil e $64 \%$ já usaram o transporte ferroviário na cidade.

O objetivo desta pesquisa de campo foi levantar dados para fomentar a analise sobre a percepção das pessoas que frequentam a região do complexo ferroviário, que utilizam este espaço para trabalho ou lazer, buscando compreender a relação dos mesmos com os bens da ferrovia e as transformações urbanas, levantando a questão entre uso e apropriação do espaço pretendendo, desta maneira compreender o significado da ferrovia para a cidade.

A busca pela compreensão do uso e apropriação do espaço pelas pessoas é interessante, pois reflete a pratica do cotidiano vivido, e como estas pessoas entendem o espaço que usufruem, possibilitando desta forma compreender a identidade atribuída ao espaço especifico em questão. 
A aplicação dos questionários abordou a percepção dos entrevistados sobre a relação entre a ferrovia e a cidade de Campo Grande, visando explorar o conhecimento das pessoas sobre a importância que a ferrovia teve para o desenvolvimento da cidade. Também foi possível levantar as opiniões dos entrevistados sobre o tombamento do complexo ferroviário.

Com o questionário foi possível compreender que a maioria dos entrevistados afirma que o tombamento foi importante e que através dele é possível preservar a historia local. No entanto, destaca-se que muitas pessoas não veem importância no tombamento, e principalmente acham que não haveria necessidade de investimentos públicos para a salvaguarda destes bens.

Com intuito de chegar ao entendimento sobre a aceitação por parte da população, das obras realizadas e se estas remetem a ferrovia foi realizada uma sequencia de perguntas (questões de 5 a 10), onde foi levantado que a maioria das pessoas aceita as obras realizadas e mesmo que sem muita alusão a ferrovia pela descaracterização dos espaços, elas acham que são importantes para a preservação da memória ferroviária na cidade, além disso, foram importantes para a requalificação urbana da cidade pois estas regiões antes estavam degradadas.

O resultado desta pesquisa foi satisfatório, pois foi possível obter dos entrevistados argumentos que afirmam a importância da ferrovia para o desenvolvimento da cidade, o que demonstra o reconhecimento da NOB por parte da população de Campo Grande. Destaca-se também a percepção das pessoas frente às obras realizadas, elas reconhecem que o espaço está descaracterizado e opinam que seria mais interessante obras com mais conexão com a ferrovia e que nos espaços onde existam fragmentos da NOB haja mais identificações que expliquem a relação destes "pedaços de história" com o espaço em seu uso atual.

O grande intuito desta pesquisa com frequentadores do complexo ferroviário "revitalizado" é justamente a busca pela compreensão do papel atual do simbolismo da ferrovia Noroeste do Brasil, entender sua inserção na atualidade e como é entendida após as reformas de requalificação.

Através das entrevistas e questionários foi possível perceber que a retirada dos trilhos incomodou tanto os ex-ferroviarios quanto a população entrevistada, mesmo com a existência de outros bens da ferrovia, levando ao entendimento que a memória ferroviária se ancora também nos trilhos que cortavam a cidade, não sendo menos importantes ou meros detalhes, eles marcaram o espaço cotidiano e estão fixos na memória. 
Isto evidencia que os entrevistados não perceberam que o tombamento não foi suficiente para preservar aquilo que também era importante, ressaltando que a retirada dos trilhos ocorreu antes do tombamento federal.

Os questionários também apontam a feira e as orlas como algo positivo, apesar de serem polemicas do ponto de vista da memória ferroviária, a primeira por não ter relação com a ferrovia e a segunda por descaracterizar o antigo traçado férreo.

No entanto estes bens estimularam o uso por parte das pessoas, do complexo ferroviário, inserindo o espaço na dinâmica urbana atual, porém sem fazer conotação com seu verdadeiro significado para a memória ferroviária, mostrando que não houve preocupação em demonstrar os sentidos e significados reais do patrimônio ferroviário, gerando um uso superficial do complexo ferroviário. 


\section{Considerações finais}

A importância contida nos bens patrimoniais vai além de seu caráter estético, as vezes motivo inicial nos processos de tombamento, o complexo ferroviário de Campo Grande prova que as relações cotidianas motivadas pelas relações de trabalho são importantes tanto ou até mais que a beleza arquitetônica de um conjunto de prédios presentes nas áreas antigas das cidades brasileiras, hoje degradadas.

Pensar sobre a construção da memória de um lugar por meio da valorização de seus aspectos históricos, que formam entre outros o seu Patrimônio Cultural, é uma tarefa que requer além de estudos específicos de caráter técnico, uma compreensão do significado atribuído a estes bens pelas comunidades nos quais eles estão inseridos, pois a memória não está apenas disponível pela percepção visual, ela é mais que um conjunto de edifícios antigos, ela está contida na produção diária dentro destes espaços.

Sendo assim olhar para as intervenções no patrimônio ferroviário em Campo Grande requer superar as aparências que se apresentam, pois mesmo com a identificação de alguns bens como a estação ou a rotunda, que sugerem claramente do que se trata este lugar, a cidade é esvaziada de seu conteúdo específico da memória coletiva, ficando apenas o espaço pelo espaço, sem uma atividade atual que possa fazer jus a história da ferrovia e a memória de seus trabalhadores na cidade.

O fato de importantes bens relacionados ao trabalho na ferrovia não terem recebido intervenção, demonstra que o processo foge ao foco da preservação da memória do trabalho na ferrovia, da memória dos trabalhadores, ficando mais explícito ainda quando estes elementos atuam como coadjuvantes neste espaço a partir da inserção de um elemento externo que foi incluso no complexo para atrair novos fluxos e circulação de pessoas para a região.

Isto evidencia que mesmo hoje preservado o complexo ferroviário ainda necessita de ações que apontem sua identificação e história com a cidade, principalmente no que diz respeito aos sujeitos do processo de trabalho na ferrovia NOB/RFFSA, que hoje presenciam a nova dinâmica urbana onde se insere o complexo, de forma apartada apenas acompanhando o apagamento de suas memórias.

Durante a análise dos documentos de tombamento por parte do IPHAN, foi possível perceber a questão da valorização efervescendo por parte da prefeitura de Campo Grande, que ao invés de salvaguardar o patrimônio enquanato conjunto, acabou colaborando com a degradação 
da ferrovia na cidade, seja pelo evento da retirada dos trilhos, seja pela inserção da feira central que não possui relação com o patrimônio, pelo contrário se usou da história local para se ancorar. E o pior tentou impedir um processo de tombamento devido a seu interesse de requalificação urbana, no caso das orlas.

Estes fatos mostram como a questão não só do patrimônio ferroviário, mas do patrimônio industrial e até de alguns casos de patrimônio cultural, sofrem com a busca de valorização econômica seja do poder público ou do privado que possuem grande interesse nestas áreas, visto questão da volta a ocupação dos centros antigos no contexto atual das cidades.

O patrimônio acaba sendo usado apenas como discurso, promovendo projetos de intervenção urbana, e atuando como coadjuvante no espaço urbano, quando não há uma melhor fiscalização e até mesmo uma tutela mais rígida sobre este espaço.

A realização das entrevistas foi muito importante principalmente devido à possibilidade de trazer a público estas memórias que são produto da experiência passada do trabalhador e que está em desaparecimento. Foi possível um contato real com estes indivíduos que fizeram parte da ferrovia e principalmente compreender através de seus depoimentos, certo tom de abandono do poder público em vários momentos de dificuldade pós-privatização e posterior tombamento da ferrovia.

É possível afirmar que o ex-ferroviário é uma figura inquieta com os rumos que a revitalização do complexo ferroviário tomou, concordam que trouxe melhorias e modernização para a cidade, mas afirmam categoricamente que não se sentem representados em nenhumas destas obras e veem a história do município sendo maquiada com cascas vazias e calçadões que servem como tapetes escondendo o verdadeiro alicerce da cidade.

Talvez o depoimento colhido de ex-ferroviários que mais síntese o sentimento presente em meio a todo o descaso com a memória do trabalhador da ferrovia em Campo Grande seja o do ex-maquinista Dudu:

"Isso aqui não tem nada de ferrovia, a gente foi contra brigou, mas a prefeitura fez...os mais antigos que foram embora da cidade quando voltam até choram quando chegam na feira e percebem o que aconteceu com o lugar que eles passaram a vida" comenta Dudu (Entrevista concedida ao autor, em Janeiro de 2013.

Com isso finalizo aqui e ainda repleto de questionamentos a respeito do processo que ocorreu em Campo Grande, principalmente por parte das ações arbitrárias da prefeitura 
municipal, que visando melhorias urbanas apagou uma importante parte da história da cidade e da memória ferroviária ali existente, memória esta que não sumiu totalmente pelo orgulho por parte dos ex-ferroviários em se reconhecerem como tal e lembrar de forma saudosa de sua história. 


\section{Referências}

ABREU, M. Sobre a memória das cidades. In: Carlos, A.F.; Souza, M. L. e Sposito, M. E. (Org.). A produção do espaço urbano: agentes e processos, escalas e desafios. $1^{a}$ ed. São Paulo: Contexto, 2011, p. 19-39.

ARRUDA, A. M. V. A difusão da arquitetura moderna em Campo Grande. Ensaios e Ciência, Campo Grande, v. 4, n.3, p. 25-54, 2000.

História da Arquitetura de Mato Grosso do Sul: origens e trajetórias.

1ª . Ed. Campo Grande: Ediçoes do Autor, 2009. v. 1000. 200p .

Uniderp, Campo Grande, v. 02, p. 50-63, 2002.

Os edifícios ferroviários da Noroeste em Campo Grande. Prosa

ARRUDA, G. A ferrovia e o povo do sertão. Arca Revista de Divulgação do Arquivo Histórico de Campo Grande, MS, Campo Grande - MS, v. agosto, n.2, p. 09-13, 1991.

AZEVEDO, F. Um Trem Corre para o Oeste: estudo sobre a Noroeste e seu papel no sistema de viação nacional, $2^{\circ}$ ed. (In): Obras Completas, Vol. XII. São Paulo: Melhoramentos, 1950.

BORGES, B. G. O Despertar dos Dormentes. In: A Era Ferroviária, Goiânia, Cegraf-UFG, 1990, cap. 1, p. 1-50.

BOSI, E. Memória e sociedade. 13ª Ed. São Paulo: Companhia das Letras, 2005.

CADONÁ, M. A. A inserção neoliberal: burguesia industrial e a inserção econômica do Rio Grande do Sul no processo de reestruturação do capitalismo durante os anos 1990, Tese (Doutorado em Sociologia Política) - Universidade Federal de Santa Catarina, UFSC, Brasil., 2009.

CANO, W. Soberana e política econômica na América Latina. São Paulo: UNESP, 2000

CARLOS, A. F. A. Espaço-tempo na metrópole: fragmentação da vida cotidiana. São Paulo: Contexto, 2001.

O lugar no/do mundo. $1^{\text {a }}$ Ed. São Paulo: FFLCH, 2007.

CASTRO, W. R.; MONASTIRSKY, L. B. O patrimônio cultural ferroviário no espaço urbano: reflexões sobre a preservação e os usos. In: $14^{\circ}$ Encuentro de Geógrafos de América Latina, 2013, Lima (Peru). Reencuentro de saberes territorialies Latinoamericanos (14] EGAL), 2013.

CHOAY, F. Alegoria do Patrimônio. São Paulo: UNESP, 2001.

COSTA, W. P. Ferrovias e trabalho assalariado em São Paulo. Campinas - SP. Dissertação de Mestrado IGCH/UNICAMP, 1975. 
FINGER, A. E. Vilas Ferroviárias no Brasil. Os casos de Paranapiacaba em São Paulo e da Vila Belga no Rio Grande do Sul. Brasília: FAU UnB, 2009. Dissertação de mestrado.

FREIRE, M.E.L; CAVALCANTI, F., BESSONI, G.; FREITAS, M. Patrimônio ferroviário: memória ou esquecimento? Abordagem conceitual no processo de valoração do patrimônio $\begin{array}{lllll}\text { ferroviário em } & \text { Pernambuco. } & \text { 2012. } & \text { Disponível }\end{array}$ <http://portal.iphan.gov.br/portal/baixaFcdAnexo.do?id=2999>. Acesso em: 10 fev. 2014

FONSECA, M. C. L. O patrimônio em processo: trajetória da política federal de preservação no Brasil. Rio de Janeiro: UFRJ/Minc/IPHAN, 1997.

GALVÃO JÚNIOR, J. L. Patrimônio ferroviário na arquitetura e urbanismo. In: FORTES, J. A. A.; CARNEIRO FILHO, A. (orgs). Seminário patrimônio histórico e cultural ferroviário. Brasília: Finatec, 2007.

HALBWACHS, M. A memória coletiva. São Paulo. Vértice, 1990.

HARVEY, D. A produção capitalista do espaço. São Paulo: Annablume, 2005.

IPHAN. Instituto do Patrimônio Histórico e Artístico Nacional. Patrimônio cultural. Brasília: Ministério da cultura, 1994.

JEUDY, H. P. Espelho das Cidades. Rio de Janeiro: Casa da Palavra, 2005.

KATINSKY, J. R. Tecnologia e Industrialização. In: Ferrovias Nacionais, São Paulo: UNESP, 1994, cap.2, p.37-65.

KÜHL, B. M. Preservação do patrimônio arquitetônico da industrialização: Problemas teóricos de restauro. Cotia, SP: Ateliê Editorial, 2008. P. 206.

KÜHL, B. M. Algumas questões relativas ao patrimônio industrial e à sua preservação. Revista do IEEE América Latina, Brasília, v. 4, p. 1-10, 2006.

LEFEBVRE, H. A Revolução Urbana. Belo Horizonte: UFMG, 2004.

O Direito a Cidade, São Paulo: Centauro, 2006.

A vida cotidiana no mundo moderno. São Paulo, Ática, 1991.

LINS, A. P. M. B. O patrimônio industrial ferroviário e os instrumentos voltados para a sua salvaguarda. Architecton - Revista De Arquitetura E Urbanismo - Vol. 02, No 02, 2012.

LUXEMBURG, R. A Acumulação do Capital, Editora Zahar, 1970.

MARQUES, P. P. Técnica, modernização e produção do espaço: um estudo sobre o papel da estrada de ferro nas transformações sócio-espaciais da zona alta sorocabana. 2009. Dissertação Mestrado em Geografia (Geografia Humana) - Universidade de São Paulo, Orientador: Francisco Capuano Scarlato.São Paulo, 2009. 
MARQUES, S. A. Privatização do Sistema Ferroviário Brasileiro. Brasília, IPEA, 1996, Texto para Discussão 434, 78p.

MATOS, O. N. Café e Ferrovias: a evolução ferroviária de São Paulo e o desenvolvimento da cultura cafeeira. São Paulo, Ed. Alfa-Omega, 1974.

MATOS, O. F. C. Os Arcanos do Inteiramente Outro: a escola de Frankfurt, a melancolia e a Revolução. São Paulo: Brasiliense, 1995.

MONASTIRSKY, L. B. Estação Ferroviária: 'lugar de memória' das cidades brasileiras. Espaço e Geografia (UnB), v. 16, p. 781-804, 2013.

Ferrovia: Patrimônio Cultural - Estudo sobre a ferrovia brasileira a partir da região dos Campos Gerais (PR). 2006, 190 p. Tese (Doutorado em Geografia). Programa de Pós-Graduação em Geografia, Centro de Filosofia e Ciências Humanas, Universidade Federal de Santa Catarina, Florianópolis, 2006. Disponível em: <http://tede.ufsc.br/teses/PGCN0292.pdf>. Acesso em 15 de JULHO. 2013.

MORAES, A. C. R. Capitalismo, Geografia e Meio Ambiente, Tese para obtenção de Livre Docência, FFLCH - USP, São Paulo, 2000.

NASCIMENTO, F. B.; SCIFONI, S. Memória e esquecimento. O patrimônio cultural dos trabalhadores paulistas. In: VI Colóquio Latino Americano sobre Recuperação e Preservação do Patrimônio Industrial, 2012, São Paulo. Anais do VI Colóquio Latino Americano sobre Recuperação e Preservação do Patrimônio Industrial. São Paulo: Centro Universitário Belas Artes, 2012. v. 1. p. 1-23.

NORA, P. Entre memória e história: a problemática dos lugares. São Paulo: Revista do Programa de Estudos Pós-Graduados em História e do Departamento de História da PUC-SP, 1981.

OLIVEIRA, A. J. As linhas do progresso: A estrada de ferro Goiás e a ascensão da cidade de Araguari 1920-1950. 2005. Dissertação (Mestrado em Geografia) Universidade Federal de Goiás, Catalão: 2005.

Organização das Nações Unidas para a Educação, Ciência e Cultura. Convenção para a proteção do patrimônio mundial, cultural e natural. UNESCO, 1972. Disponível em: < http://whc.unesco.org/documents/publi_basictexts_pt.pdf>. Acesso em: 10 Jul. 2012

PEIXOTO, J. B. Os Transportes no Atual Desenvolvimento do Brasil. Rio de Janeiro: Biblioteca do Exército, 1977, v. 147, p. 15-19.

PRADO JR., C. História econômica do Brasil, 45ª reimpressão. São Paulo: Brasiliense, 1998. QUEIROZ, P. R. C. Uma ferrovia entre dois mundos: a E. F. Noroeste do Brasil na $\mathbf{1}^{\mathrm{a}}$ metade do século XX. 1 ${ }^{\text {a }}$. Ed. Bauru: EDUSC, 2004. v. 1. 526 p. 
QUEIROZ, P. R. C. As curvas do trem e os meandros do poder: o nascimento da Estrada de Ferro Noroeste do Brasil - 1904 / 1908. Cuiabá: Editora da Universidade Federal de Mato Grosso do Sul, 1997.

RODRIGUES, A. R. Patrimônio industrial e os órgãos de preservação na cidade de São Paulo. Revista CPC (USP), v. 14, p. 30-56, 2012.

SANTOS, C. N. F. Preservar não é tombar. Renovar não é por tudo abaixo. Revista Projeto, São Paulo, n. 86, 1986.

SANTOS, M. A Natureza do Espaço: Técnica e Tempo, Razão e Emoção. $4^{\text {a }}$ ed. São Paulo: USP, 2006.

A urbanização brasileira. $5^{\text {a }}$ Ed. São Paulo: Edusp, 2005.

Espaço e Método. $3{ }^{\text {a }}$ Ed. São Paulo, Nobel, 1992.

Pensando o Espaço do Homem. São Paulo: Hucitec, 1980.

Técnica, Espaço, Tempo: Globalização e Meio Técnico-Científico-

Informacional, Editora Hucitec, São Paulo, 1994.

SCIFONI, S. Patrimônio mundial: do ideal humanista à utopia de uma nova civilização. Geousp (USP), São Paulo, v. 14, p. 77-88, 2004.

SOUKEF JUNIOR, A. A Preservação dos Edifícios da São Paulo Railway em Santos e Jundiaí. 1 ${ }^{\text {a }}$. ed. São Paulo: Annablume Editora; FAPESP, 2013. v. 01.

SOUZA, A. J. C.; SOARES, B. R. A demolição do Conjunto da Estação da Antiga Mogiana de Estrada de Ferro em Araguari - MG: Decadência ferroviária e aspirações urbanizadoras. Observatorium - Revista Eletrônica de Gografia, v. 2, p. 64-87, 2010.

TRUBILIANO, C. A. B.; JUNIOR, C. M. Rumo à brasilidade: Mato Grosso e a Marcha para o Oeste (1937-1945). In: X Semana de História UFMS/CPTL, 2007, Três Lagoas. Anais, 2007.

WEINGÄRTNER, A. Antonia dos Santos. Campo Grande - o impulso do desenvolvimento nas rotas de gado, nos trilhos do trem e nos caminhos do Mercosul. Arca, Campo Grande, n. 5, p. 39, outubro, 1995. 
Anexos

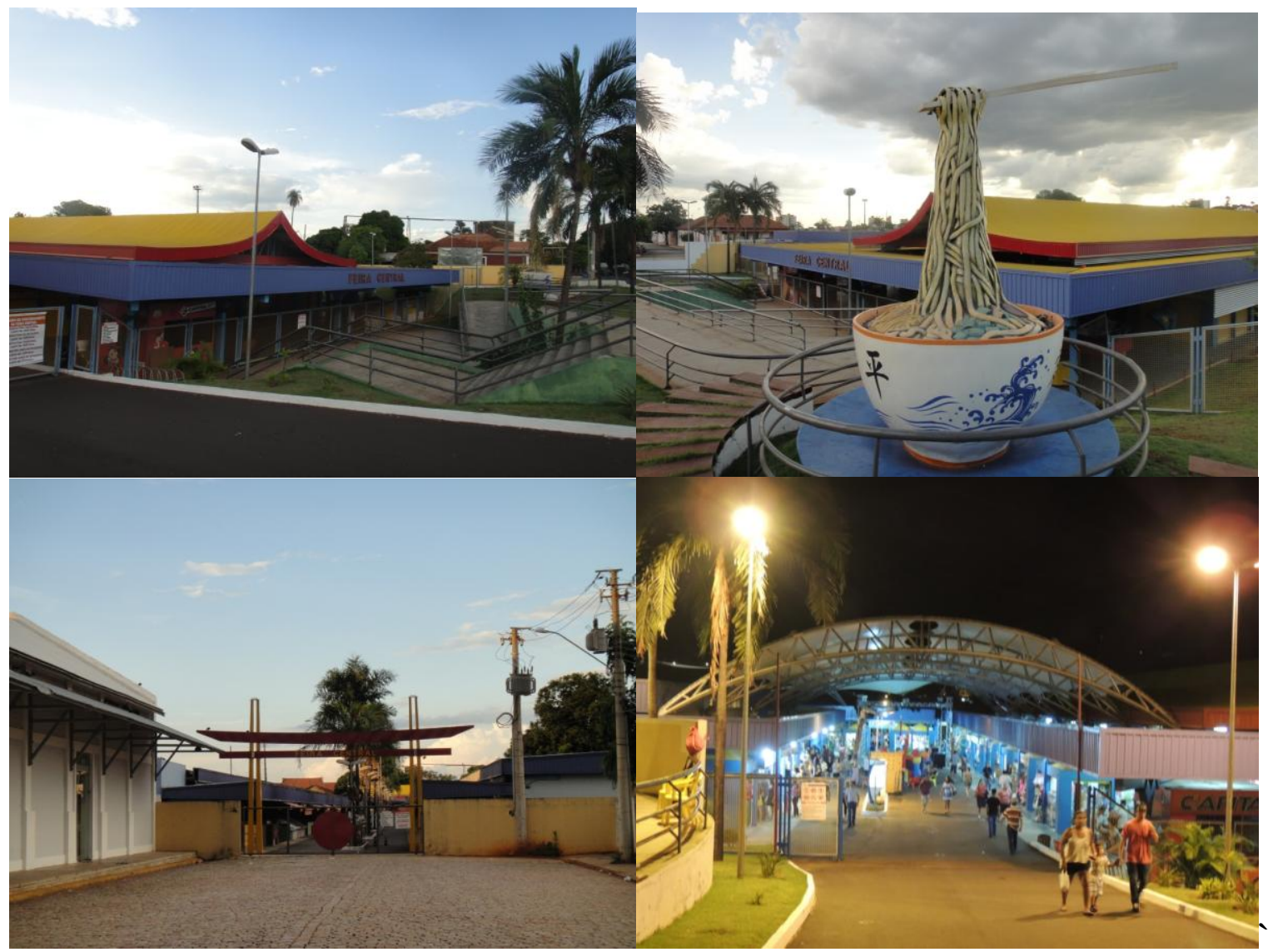

Fotos Feira Central em Campo Grande, janeiro de 2014, próprio autor. 